\author{
Universidade de São Paulo \\ Escola de Comunicações e Artes \\ Departamento de Artes Cênicas \\ São Paulo
}

RUDSON MARCELO DUARTE

\title{
No teatro todo corpo é máscara: A prática do mascaramento e seus desdobramentos a partir do trabalho do Théatrê du Soleil.
}

\author{
DISSERTAÇÃO APRESENTADA PARA \\ obtenção de título de Mestrado \\ STRICTU SENSUS \\ Orientador: Prof. Dr. FELISBERTO \\ SABINO DA COSTA \\ Área: Teoria e Prática Teatral
}


Agradecimentos

Agradeço a Delminda Macella Duarte, pela transcendência. Aos presentes que fui colecionando durante a dissertação, os problemas e as noites sem sono. A minha mãe, por ser sempre, e a Alex Fabiano Nogueira, por ser e estar, a Felisberto Sabino Costa, uma orientação que me ensinou não só a pesquisar, mas a buscar e me arriscar, Ipojucan Pereira, pela devoção de amizade, a Ana Cristina Colla, pela poesia e pelo olhar tão atento e carinhoso, a Eduardo Coutinho pelas palavras e Sônia Machado Azevedo, pela disponibilidade tão cara a artistas, a Stephan Brodt, pela deliciosa entrevista e pela arte, ao Círculo Grupo de Estudos Híbridos da cena, ao meu amigo Ronaldo Zaphás por entender as não noites e Francisca Mônica, pelos telefonemas desesperados que dávamos em plena noite. E por fim, mas nunca menos importante, a Ariane Mnouschkine, que me ensinou em trinta dias de estágio mais do que poderia, obrigado pela inspiração e pela arte. Enfim, agradeço...agradeço e agradeço cada demonstração de carinho, que me mostrava a beleza como caminho 


\section{Resumo}

A relação entre a linguagem da máscara e o corpo do ator é estudada desde o início do século XX por diversos artistas-pedagogos, como Gordon Craig, Jacques Copeau e Jacques Lecoq. Mas a influência dessas pesquisas no trabalho dos atores do Théatre du Solei entende uma perspectiva diferencial acerca de como esse corpo reage e se deixa afetar durante a experiência com a máscara. Essa pesquisa busca entender os traços significativos dessa escrita do Soleil, realizada com máscara no corpo do atuante e seu mascaramento resultante: o corpo-máscara. Através de estudos sobre o Interacionismo Simbólico de Goffman, da neurociência de Mark Johnson e da sua relação com os trabalhos artísticos integrados de Helena Katz e Christine Greiner, buscamos observar como a relação do corpo com o atravessamento simbólico da máscara pode criar uma cognição e imagética para o ator, ao mesmo tempo esse olhar fora conduzido para uma aproximação com o trabalho artístico com as máscaras no Soleil, para depois realizarmos uma experimentação laboratorial, que nos pudesse fazer entender esses traços em uma prática, que elucidasse tais conceitos e perspectivas. 


\section{Abstract}

The relationship between the language of the mask and the body of the actor has been studied since the beginning of the twentieth century by several artists-pedagogues such as Gordon Craig, Jacques Copeau and Jacques Lecoq, but the influence of these researches on the work of the actors of Théatre du Soleil, A differential perspective on how this body reacts and lets itself be affected during the experience with the mask. This research seeks to understand the significant features of this writing of Soleil, performed with a mask on the body of the actor and its resulting masking: the body-mask. Through studies of Goffman's Symbolic Interactionism, Mark Johnson's neuroscience, and his relationship to the integrated art works of Helena Katz and Christine Greiner, we sought to observe how the relation of the body to the symbolic crossing of the mask can create a cognition and Imagery for the actor, at the same time this look was led to an approximation with the artistic work with the masks in the Soleil, and then to carry out a laboratory experimentation, that could make us understand those traces in a practice, that would elucidate such concepts and perspectives. 


\section{SUMÁRIO}

Introdução.

Relato 1

Capítulo 1 - Como dar forma a uma paixão: a relação do corpo do atuante com o objeto máscara

1.1. Diminuindo as fronteiras entre o corpo e o imaginário

1.2. A máscara como mídia

1.3. A criança e o espelho

Capítulo 2 - 0 dentro e o fora: o corpo-máscara no Théâtre du Soleil e sua relação com os mascaramentos contemporâneos 50

2.1 O corpo-máscara no Soleil

2.2 O mascaramento contemporâneo e sua relação com 0 corpo-máscara

Relato 2

Capítulo 3 - O corpo-máscara observações práticas de trabalho

Conclusão

Referências Bibliográficas 


\section{Introdução}

Essa não é uma dissertação sobre o Théatre du Soleil, nem tão pouco sobre Ariane Mnouchkine. Essa é uma dissertação sobre os aspectos da máscara observados nos treinamentos do grupo e, mais especificamente, sobre a sua ausência, enquanto objeto, na atuação de seus atores e sua presença, enquanto fenômeno, nos aspectos simbólicos do corpo dos atuantes desse grupo. Essa ausência, que reflete uma presença dialógica, possibilitou um entendimento diverso dos procedimentos observáveis nos trabalhos tradicionais sobre a máscara no Soleil pois, por mais que sua diretora não afirme um procedimento único de condução de seus atuantes, ela muitas vezes realiza, através das máscaras de Erhard Stiefel, o disparador de jogos para a criação de vivências e personagens para seus atuantes.

Assim, esse trabalho dialoga com os procedimentos de transmissão dos códigos da máscara para o corpo do atuante no Soleil, perpassando a poética desenvolvida pela diretora em acordo com seus parceiros de investigação e os dispositivos desenvolvidos por eles como disparadores dos jogos de máscaras do grupo, utilizados constantemente pela diretora no desenvolvimento de suas montagens.

Segundo Aline Borsari, atriz do Soleil desde 2009, em entrevista para essa pesquisa, a linguagem expressiva da máscara "(...) é transmitida quase que como osmose dos atores mais antigos do Soleil para nós" (BORSARI,2017). Esse procedimento, aventado pela atriz, é aqui entendido na reflexão da mediação da linguagem da máscara, mesmo que fora da cena, e nas relações que ela estabelece como estruturação de jogo no grupo. Uma camada significativa, como um invólucro, que confere uma expressividade distinta, assemelhada à linguagem, conferida pela máscara.

A diretora desenvolve, por meio da máscara, não uma forma de esconder o ator, mas uma potência reveladora para a criação atoral, indicando-a como uma maneira de domar o interno, possibilitando que esse atuante transite entre os limites estabelecidos pelas partituras criadas no jogo com a máscara, desenvolvendo uma música interna como mecanismo de geração 
de presença. É nos jogos que Ariane cria formas que possam dar conta do deslumbre estético que busca atingir com seus espetáculo, que através dessas formas costura uma dramaturgia atoral paralela à dramaturgia textual utilizada nos espetáculos. Assim, podemos observar clássicos de Shakespeare mixados à dança-teatro Khatakhali, ou tragédias gregas atravessadas por poéticas de atuação orientais. $\mathrm{Na}$ verdade, apesar de Ariane afirmar a não vinculação a uma metodologia específica para a construção de seus espetáculo, são as máscaras orientais e as da Commedia Dell'Arte seus dois grandes nortes de experiências com o objeto, mas não os procedimentos clássicos de linguagens dessas máscaras, e sim um recorte dos seus tipos e arquétipos reatualizados, que ao mesmo tempo mantém uma ancestralidade imanente para a fuga de uma atuação realista pautada na psicologia do ator, que lhe proporciona "uma forma radicalmente teatral, extremamente transposta, (...) para nos impedir de afundar no realismo. O realismo: eis o inimigo "(MNOUSCHKINE, 2011:60).

Ariane, afirma um teatro representante de um povo, um teatro coral, em que o personagem é um reflexo de uma sociedade e de sua cultura, um recorte historicizado que remete a arquétipos que nos vinculam e nos representam. A máscara, sobre esse aspecto, é uma ligação direta com esse homem político, um traço estético e ético de expressividade humana. Ainda sobre esse aspecto, Mnouschkine não se vincula a nenhuma ideia de teatro atual. Contudo, apesar dessa negação, a diretora produz uma abordagem muito contemporânea de utilização da máscara, pois produz mixagens entre um passado ritual das máscaras e uma abordagem atual dos tipos das máscaras da Commedia Dell'Arte e, em alguns espetáculos, promove esse mascaramento físico do atuante ao pedir que ele não se utilize da máscara na materialidade da cena, mas que se aproprie dos seus códigos de jogo e arquétipos como expressão para a criação de seus personagens, desenvolvendo assim um ligame entre uma tradição de máscaras e uma reatualização contemporânea, tanto dos temas envolvidos nas peças, quanto nas poéticas de cena realizadas em seus espetáculos.

Seria possível, ainda, descrever o trabalho de Ariane sob diversos aspectos: artista complexa, representante de um certo teatro que se associa à linhagem de pesquisadores, tais como Jacques Copeau, Jean Dasté, Jacques Lecoq, 
Antonin Artaud e outros, bem como poderíamos abordar sua influência do teatro oriental e suas codificações no grupo, além do multiculturalismo. Ou mesmo abordar seu teatro sobre os aspectos políticos influenciadores de um discurso dramatúrgico elaborado em suas montagens observando, em seu trabalho, o desenvolvimento temático e os enfoques que orientam cada uma de suas encenações, sempre com base na prática e nunca em estudos teóricos de próprio punho, isto é, nunca orientada por uma ideia estética prédeterminada, que possa criar uma linha fixa de entendimento de suas criações, já que a diretora se recusa à escrita de uma documentação que relacione sua prática e seus pensamentos.

Assim, sem querer criar uma perspectiva normativa e estanque da relação da máscara com o corpo no grupo, esse trabalho se debruça sobre o entendimento acerca do mascaramento físico em geral e toma como índice a produção desse fenómeno no grupo francês, tendo como linha mestra a busca por essa fenomenologia contemporânea do corpo atravessado pelos signos do objeto máscara na dinâmica dos jogos de cena.

Iniciamos a pesquisa identificando esse corpo máscara no Soleil e entendendo como esses atravessamentos são entendidos no teatro contemporâneo. No primeiro capítulo, identificamos essa ocorrência tendo em vista as teorias da presença e a relação da potencialização na atuação em fricção a máscara. Observamos que os entendimentos acerca da presença no teatro se desenvolvem na imbricação dos dispositivos tecnológicos na cena e suas relações com o corpo do ator, processo que, ao longo do tempo, foi determinando o afastamento da figura humana do palco e afirmando os dispositivos geradores de ficcionalização no interior do acontecimento cênico. Porém, distinguimos a relação dessas mediações tecnológicas com a máscara no mascaramento corpo-máscara e observamos que os traços, que qualificam a mediação tecnológica e a mediação da máscara com o corpo, dialogam e nos permitem inferir certo traço distintivo da mídia presente também na máscara.

Assim, observamos que o rastro deixado na presença física do ator pelo objeto se coaduna a uma perspectiva contemporânea da cena que é praticada por Mnouschkine, mesmo que na transmissão osmótica dos atores 
veteranos para os mais novos e, principalmente, pela condução dos jogos na relação com os dispositivos geradores de cena e a máscara.

Confrontando essas observações com a prática relatada do Soleil, quisemos então entender a relação íntima que se processa entre o corpo e a máscara, sob a perspectiva do mascaramento aqui estudado, pois observamos que, dependendo da percepção que se adote para o corpo e dependendo de que máscara se aborda como linguagem, chegamos a diferentes perspectivas de análise. Assim, no segundo capítulo, focamos nos conceitos filosóficos de corpo que pudessem relacionar-se com as qualidades entendidas no objeto. Entretanto, não elegemos uma máscara em particular, mas sim as qualidades essenciais e gerais da linguagem, isso porque compreendemos, nos procedimentos do Soleil, que independentemente de serem tipos da Commedia Dell'Arte ou o Kathakali, a maneira como um ator deve abordar o objeto no grupo permanece ligada aos princípios didáticos da máscara como mediadora da expressividade do corpo do ator, entendidos no capítulo 1. Dessa forma, quisemos observar não uma linguagem estética específica que coaduna-se ao entendimento sobre o corpo, mas sim as qualidade de abordagem da máscara que o atuante deve desenvolver na sua aproximação com o elemento, bem como o resultante expressivo possibilitado pela máscara em seu corpo, respondendo a questão: no que a máscara se diferencia de outros objetos na criação atoral? A conceituação do norteamericano Mark Johnson sobre o desenvolvimento de cognições nas dinâmicas físicas nos auxiliaram com a compreensão acerca do processamento imagético criado na cena e, auxiliados pelas perspectivas de Helena Katz e Chistine Greiner sobre o Corpo-mídia, que perscruta a teoria de Johnson sobre o ponto de vista da dança e da performance, nos permitiram inferir sobre esse processo de Johnson no corpo em dinâmica com a máscara, o que norteou as definições sobre os qualitativos da mediação fenomenológica da máscara sobre o corpo do ator.

Esse processo corpo-mídia e máscara-mídia nos permitiu entender que ambas as potências se atualizam em fluxos de experiências, que promovem a geração de campos de força pela ruptura dos padrões psicofísicos do atuante gerados pela experiência com a máscara em resposta, no caso do Soleil, aos dispositivos de jogos da cena. Como resultante, a gestualidade, 
ações e movimentos dos atuantes do grupo são então como que recobertas por uma camada significante da máscara sobre o corpo, que percebemos como o mascaramento corpo-máscara: um fluxo contínuo e disruptivo dos mecanismos de legitimação de certa massificação no corpo do atuante, que o faz gerar uma resposta expressiva ativa que atua sobre os afetos e perceptos do atuante.

Durante oito meses, laboratoríamos esses entendimentos, tentando alocá-los em procedimentos que pudessem nos fazer entender, na prática, aquilo que a teoria não foi capaz de conter. No terceiro capítulo, realizamos nossas ponderações e compreensões embasadas na experiência de condução de um grupo de atores recém-formados e com nenhuma familiaridade com a linguagem da máscara. Nesse processo, conseguimos nos aproximar da poética de Mnouschkine, com a qual o pesquisador havia realizado um workshop e nos servimos das anotações realizadas, tanto nesses encontros com a mestra francesa, quanto com a notações de dois atores que vivenciaram esses procedimentos no Soleil e nos conferiram entrevistas para essa dissertação. As ponderações observadas não pretendem abarcar a complexidade da prática com máscara desenvolvida por Ariane, mas sim nos permitir uma imersão de nosso próprio olhar sobre o corpo em contágio com a máscara.

Dessa maneira, orientamos uma pesquisa que percebe Ariane como um norte, mas que sabe de seu alcance, que a pressente sem abarcá-la, e que é a todo momento atravessada por sua inspiração, mantendo o foco sobre esse mascaramento e seguindo os rastros deixados pela presença material do Soleil, que nos permitiu analisar concepções sobre o corpo e sobre a máscara e o acontecimento do seu amalgamento. Essa é uma pesquisa sobre a natureza expressiva desse corpo, que aceita e joga com essa potência metamorfoseante que lhe promove alterações físicas, imagéticas e cognitivas, tornando-o um corpo que é máscara na cena. 


\section{Relato 1.}

Um olho de madeira me observa ao mesmo tempo em que eu o observo em retribuição, um entrecruzamento de olhares em que um certo desafio se faz dele para mim: será possível que me vista e me faça vivo? Em retribuição ele me redesenha, me induz, me troca de mim mesmo, provoca e marca meu corpo. E mesmo quando esse olho não mais estiver envolvendo o meu próprio olho, o diálogo direto comigo ainda estará ocorrendo em algum lugar, pronto para dominar novamente meu corpo e me possibilitar ser um outrem, enquanto sou mais intensamente eu mesmo.

Os olhos se aproximam da minha face, eu respeitosamente aceito suas regras e as deixo viver em mim na duração do presente do presente, no momento exato em que é possível que eu me veja deslocado de mim e mais próximo da vivencia ofertada por esse jogo de me esconder de mim mesmo, e nesse deslocamento me vejo potencia em movimento, me vejo atuando em intensidade, eu o ator agora vestido dela a máscara, ela não mais somente objeto, mas sim vida em meu corpo. Eu a visto objeto enquanto ela me veste potência.

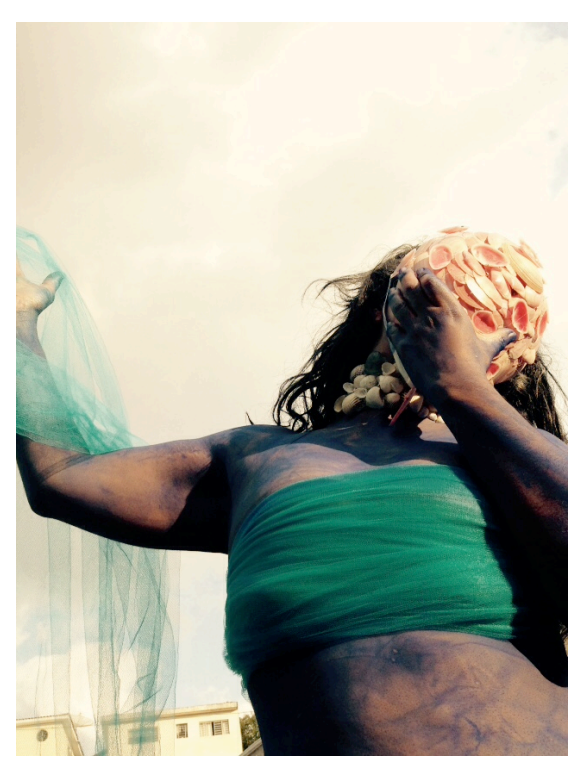

Nesse jogo de esconde-esconde, no qual se revelam intensidades tanto em mim quanto na codificação física da própria máscara, o fazer de conta e o brincar de ser, suspende certos automatismos da figura do atuante enquanto possibilita novas relações espaço-temporais para dinamizar, no sentido de dar vida, a essa máscara.

Eu não me perco de mim, mas sim me uno a esse outro que sou eu mesmo, me abrindo as possibilidades que eu mesmo me impeço, sou eu ficção, eu no cumulo de mim mesmo, não repartido, atuante em sintonia com algo mais abissal de mim. Conectado através e atravessado por esse objeto em meu rosto. 


\section{Capítulo 1. Como dar forma a uma paixão: A relação do corpo do atuante com o objeto máscara.}

Deixa teu corpo entender-se com outro corpo. Porque os corpos se entendem, mas as almas não. Manuel Bandeira- Arte de Amar, 1948

O corpo humano é uma potência atravessada por uma multiplicidade de fatores externos, que emana e recebe, ao mesmo tempo, possibilitando infinitas formas de interações com o meio, e, dessa relação, com a cognição do indivíduo, que por consequência geram ações e reações nesse trânsito entre o eu e o meio.

Poderíamos afirmar no corpo uma certa geografia íntima do eu, quase como um mapa que nos conduzisse por fissuras, emaranhados e desertos, que nos fizesse antever o indivíduo em estado de latência dinâmica em suas respostas interativas com cada advento de seu continuun, essas respostas muito embora pareçam inventadas no ato da resposta, estão muito ligadas a historiografia do ser, isto é, sua cultura, modus e meios de relação com o espaço e o tempo, que por mais que modifiquem-se, ainda permanecem como traços significativos desse indivíduo, assim, nos permitindo observar nas respostas à essas interações onde encontra-se "o povo" que habita esse espaço geográfico do ser. O corpo é a materialidade do EU, onde acontece o ser e por onde ele é afetado.

Muito embora pareça difícil definir um EU, o Interacionismo Símbólico, descrito por diversos autores como Goffman, Blumer, Denzin, e tantos outros, nos aponta uma possibilidade interpretativa dessa figura sobre os aspectos de suas relações. Horta Nunes nos aponta que

\footnotetext{
"O EU corresponde ao aspecto "puro" do self, ao "sujeito", a um sentido de identidade pessoal. É muito difícil investigar cientificamente o EU, pois ele é a entidade que permanece no fluxo dos transitórios estados de consciência. Por outro lado, o Mim corresponde ao aspecto empírico do self, que James equipara a auto concepção, ou ao self como objeto. 'á o mim material, que inclui tudo: o corpo, as roupas, o núcleo familiar, as coisas que possuímos, (...)" (NUNES HORTA, 2005: 49)
} 
Sobre essa perspectiva, a investigação do EU, nessa pesquisa, não é apontada sobre a forma das inferências dos fluxos de consciência das experiências do ser, mas sim no ponto de vista dessa materialidade objetiva do corpo, e de seus desenvolvimentos tanto simbólicos quanto materiais, isto é: o corpo em uma vivência específica desenvolve uma forma adaptativa que Ihe possibilita certa cognição e também um modus de comportamento, no qual sua própria estrutura física é alterada, tanto no comportamento quanto na própria forma com que se apresenta. Esse processo adaptativo, não inclui a ideia behaviorista de resposta a certos estímulos da experiência, o que tornaria o ser um copiador das figuras e comportamentos sociais préestabelecidos, mas sim na emergência do significado para os participantes de determinada interação.

Assim, quando o corpo é atravessado pela interferência da máscara na relação com o ambiente que o envolve, ela revela uma materialidade arquetípica, que atualiza esses aspectos historiográficos culturais, contidos no corpo do humano, realizando dessa maneira concretudes poéticas na cena, através dos meios e formas de interação e relação do ser. A máscara revela e é revelada ao mesmo tempo, faz emergir o múltiplo do indivíduo, esse povo que o habita, dá luz e escuridão, em um jogo de revelar-se e esconder-se por meio dela, reconhece no indivíduo sua maneira de estar e o convida a desalojar-se de si para ir viver um outrem, que é ele mesmo, anunciado na sua fisicidade, a máscara o faz transitar dentro e fora, dois aspectos dialógicos presentes na intersecção da máscara nos trabalhos de atuação. Porém quando cessada a experiência com a máscara o corpo ainda pode revisitar esse contato através de rastros simbólicos que somente esse objeto pode exercer sobre o corpo do ator, e criar uma amalgama corpomáscara, que entende uma potência artística, um mascaramento fenomenológico realizado nesse fluição do self, da máscara e do ambiente, que atuam coletivamente no corpo em cena desse ator mascarado.

Esse mascaramento será aqui investigado no trabalho dos atores do Théâtre du Soleil, que oriundos de várias nacionalidades dialogam através da máscara como instrumento de treinamento e criação, mas principalmente como ferramenta de emergência da diversidade cultural nos corpos dos atuantes e de distanciamento do psicológico do ator, que para Ariane 
Mnouschkinne, diretora do grupo, atuaria contra a revelação que o jogo com as máscaras possibilita. Mnouschkinne, dessa forma, afirma a máscara como base de criação para o seu ator, ponte transitiva para o jogo entre eles e suas distintas culturas, e principalmente como forma de emergir e imergir para o ator, que posteriormente a retira de seu rosto para vesti-la em seu corpo, criando essa conexão distinta do objeto com o corpo, esse estar em máscara, que Ihe cria uma camada significativa e simbólica distinta.

É necessário, assim, entender de quais conceitos de corpo partimos para distinguir essa relação, para que posteriormente possamos observar a influência da máscara sobre ele, pois dependendo da interpretação acerca do corpo, a influência da máscara sobre ele é alterada. Assim, nesse trabalho, decidimos abordar somente as influências gerais da utilização do objeto sobre o corpo, pois acreditamos que cada máscara e sua cultura específica seria um campo vasto de abordagem e análise de sua fenomenologia. Também decidimos por inferir as influências do público sobre aspectos gerais, para que não esbarremos nas teorias de recepção, que já abarcariam outros entendimentos acerca da ligação corpo e máscara.

Observamos, então, que o corpo é um suporte de entendimento humano e que guarda em si uma historiografia, com suas experiências, vivências, cognições e uma cultura, que relaciona sua forma de experienciar a vida e sua mediação simbólica do mundo, e quando em estado de criação artística teatral, toda sua experiência e suas perspectivas imagéticas e cognitivas são colocadas em jogo: gestos, ações e movimentos, e suas referências subjetivas tornam-se textos objetiváveis, a partir da tessitura criada da interação com os materiais de jogo em torno de sua criação. O ator, em cena, é seu próprio suporte de criação e seu próprio gerador dinâmico de transcendências. Segundo Meyer-Nunes:

\footnotetext{
"Atento a si, ao meio e ao instante presente, o corpo do ator abre-se simultaneamente à experiência imediata e a situação pré-estruturadas, como convém ao jogo teatral. Esse estado de atenção não dirigida abre caminho para a vivência do aqui e agora, uma espécie de estado passivo-alerta, que também pode propiciar, e por que não, um caminho para as ações dramáticas juntas" (MEYER-Nunes apud Greiner, 2010:116)
} 
Quando a máscara atravessa essa linha criativa elaborada pelo atuante, ela o coloca em face de si próprio, mais conectado com essas forças elementares de criação, conhecendo melhor seus campos de interação. Isso se realiza quando o ator, na dinâmica com a máscara, se afasta de seu eu psicológico criando uma conexão dicotômica com a figura a ser representada, e, dessa maneira, se estabeleceria um campo de alteridade, em que o ator revelasse ao mesmo tempo em que faz uso do objeto como mediador ${ }^{1}$ de si, do outro e do ambiente relacional em que a atividade criativa está sendo desenvolvida. O objeto máscara, pode ser percebido como uma estrutura com fissuras, lacunas significativas por onde se alojam as subjetividades interpretativas do sujeito, como diz Merleau-Ponty: “As coisas, que devem ao mundo o seu sentido, não são significações oferecidas à inteligência, mas estruturas opacas(...) e seu sentido ultimo permanece embaralhado"(MERLEAUPONTY, 1994:447), portanto bastando ao homem realizar a interpretação subjetiva dele para si e para o outro, assim, entendemos que a máscara, como objeto, é um instrumento de comunicação, e em uma montagem cênica, vemos que enquanto meio de comunicação ela interconecta receptores e atuantes, ao mesmo tempo em que cria para o ator uma ponte correlata entre o seu corpo e sua potência criativa. Dessa maneira, a máscara possibilita, por meio de sua lacunas interpretativas, a criação de uma materialidade do imaginário, que pode ser inscrita no corpo ao mesmo tempo em que dá luz a cultura nativa do atuante na sua fisicalidade. Por outro lado, o objeto também é o suporte físico de comunicação de uma cultura específica na cena, que tanto pode ser familiar ao atuante quanto completamente distinta deste, como em Les Atrides, em que Ariane utiliza o

\footnotetext{
${ }^{1}$ A própria relação dos homens com os objetos criados por suas culturas apresentam traços significativos da mediação social de sua época, pois o "objeto marca ou traça as relações mantidas pelos indivíduos uns frente aos outros" (LEVY,1996,130), e portanto realiza uma forma de comunicação por meio da sua manipulação e articulação significativa; esses traços podem guiar pesquisadores a traçar dados importantes de determinadas civilizações e as relações internas dessas comunidades. O objeto, supostamente, também marca como suporte físico, uma história da arte pautada pela mediação historiográfica das sociedades e de seus entendimentos culturais, como no caso da pintura com o suporte do objeto tela, na escultura com os objetos pedra, bronze ou outros. Porém, a máscara, enquanto objeto,
} 
Khathakali para atores de diversos países. Essa distinção entre uma cultura natural do ator e uma distinta ou naturalizada, estabelece um certo grau de dificuldade ou familiaridade com o qual o corpo reage às provocações da codificação definida pela máscara, se estabelecermos que quando treinado sobre determinada linguagem e já natural aos seus códigos o corpo aprende mais facilmente a responder às artificialidades previstas no contato com a máscara e portanto flui mais facilmente a vivência do jogo(atores treinados na Commedia Dell'Arte ou no teatro Topeng, por exemplo), por outro lado, quando responde a um código de uma cultura estranha ele se coloca em uma zona de tensão que cria um distanciamento pela não naturalidade cultural, que exerceria um ruído de comunicação com os códigos previstos naquela máscara, entretanto notamos que independentemente da situação de naturalidade com o qual o ator se vê na relação com a máscara, esse contato sempre gera um conflito do ponto de vista do corpo, por mais que exista uma diferenciação entre um corpo treinado na técnica e natural a certa cultura, que apreende e responde as sugestões codificadas e do corpo leigo em determinada forma de máscara, isso porque o objeto força o corpo a entrar em uma dinâmica de trabalho, que the exige empenhar-se na ação e com isso criar artifícios para responder a esse objeto outro colocado em sua face. Essa relação com a máscara, do ponto de vista do público, possibilita um distanciamento da figura do ator e um aceite dos códigos estabelecidos pela performance com o objeto na cena, gerando um efeito ficcional, que em detrimento da historiografia da audiência interfere diretamente na fluição e compartilhamento da ambiência relacional e portanto, também interferem na significância dos símbolos envolvidos na atuação do ator com a máscara. Entendemos que em qualquer teatro a interferência do público sobre o atuante realiza uma diferenciação fenomenológica sobre a materialidade do espetáculo, e também sobre o campo sensível em que atua o corpo do ator. Contudo, quando entendemos certas dimensões interpretativas do físico no contemporâneo, podemos observar que a máscara realiza uma mediação objetiva ao provocar um efeito de metamorfose na materialidade do que é visto em dinâmica corporal, independente do engajamento psicofísico de quem a manipula, além de receber as interferências sensíveis do seus 
observadores no ambiente relacional em que interagem, provocando uma relação mediada e potencialmente ficcional.

Dessa maneira, o corpo pensado em suas dimensões fenomenológicas, de interações com a máscara como um dispositivo transitivo que lhe cria rupturas, é a chave para entender esse mascaramento amalgamado do corpo-máscara. O corpo está entre os objetos do mundo, ele é um corpo sempre em relação e em constante atualização de subjetividades estabelecidas pela ideia da transcendência sensível, sendo ao mesmo tempo "coisa física ou matéria e o que experimento nele e sobre ele" (HUSSERL, 1976:36), e portanto vive-se a corporeidade na forma interna e externa. Sobre esse aspecto o mundo seria como a pele do corpo, ele o englobaria entre todas as coisas, e o corpo estaria constantemente se reconstituindo nesse campo relacional.

É a partir do corpo fenomenológico que podemos entender a atualização e ruptura que a máscara promove quando o atuante a veste, esse contato é um fenômeno dentro do mundo objetivo, mas também ocorre uma dupla experiência: por um lado, descubro a máscara através de seus aspectos formativos (desenhos, contornos, cores e etc.), logo, uso meu corpo para conhecer e reconhecer esses aspectos do objeto. Por outro lado, esta experiência tem um sentido sensível, pois através dela promovo uma vivência dinâmica ficcional, que se registra nos aspectos subjetivos atualizados em meu corpo pela experiência. Logo, há um eco da máscara no físico, pois a apreendo como um objeto do mundo, na exterioridade, mas, simultaneamente, recebo as impressões sensíveis internas. Essa dualidade permite que o corpo faça experiência de si mesmo como sensível e senciente, como aquele que toca na máscara e é tocado e atravessado pela experiência com ela. Essa análise nos possibilita entender como um atuante, no ato de mascarar-se, desnuda-se ao mesmo tempo em que reveste-se do outro, que vai sendo construído na dinâmica com a máscara. 
Metaforicamente, Stephan Brodt ${ }^{2}$, conta uma história criada por Helene Cixous, em sua estadia pelo Soleil, que nos ajuda a entender essa fenomenologia das máscaras:

\footnotetext{
"Uma pessoa bate na porta e outra pessoa muito velha vai atender. "Quem é?" Pergunta a velha senhora. "Sou eu", responde o visitante. E ela: -vá embora, não te reconheço. A pessoa então se vai, passase um ano e ela retorna, pois queria muito ver a velha senhora. Bate à porta, a velha pergunta:- "quem é?" E a pessoa, que havia refletido muito durante esse um ano, responde:- "sou você!" $E$ eis que a velha abre a porta, "pode entrar, já que te reconheço" (BRODT,2016)
}

Essa parábola de Cixous, contada por Brodt, nos remete a alteridade como um fenômeno de tocar-se e ser tocado por meio da máscara, ao desnudamento que a máscara propõem como potência gestual no físico. Acessando ao mesmo tempo o corpo objetivo e o corpo subjetivo, que se amalgamam, se atualizam e se experienciam conjuntamente nessa relação. Vivenciando um estado coletivo de ser o outro e ser a si, atributo da máscara que destaca os arquétipos humanos como representação cultural e social através da alteridade em jogo.

Distinguindo-se, assim, as qualidades materiais técnicas da qualidade sensível, porém sem que se separem tais qualitativos, pois ambas estão alinhadas na vivência do corpo com a máscara e no registro residual que a experiência cria no corpo, possibilitando uma potência em devir e atualização constante deste, que se relaciona com a experiência da máscara, observada, sobre essa perspectiva, como um objeto de ruptura do continuum desse corpo, que através de sua manipulação pelo atuante, torna possível indicar uma resposta que ligue o pensamento e a ação, e uma experiência mais intrincada do atuante com si e com o outro, que, dessa forma, atuaria conectando suas percepções e sensações internas a forma gestual criada em seu externo, portanto, diminuindo a distância dialógica do sujeito e objeto, e traços dicotômicos como natural/artificial, interno/externo. Ponty já nos indicava que "Não existe identidade nem não identidade, nem não coincidência, existe o fora e o dentro girando um em torno do outro" (MERLEAU-PONTY, 2004: 237) e portanto, sobre esse olhar, essas

\footnotetext{
${ }^{2}$ Em entrevista concedida para essa pesquisa.
} 
potências: sujeito/objeto, interno/externo, se relacionariam em conjunto, complementarmente, quase como uma dança, que poderia resultar na construção de linguagem atoral para a cena, em fusões e mesclas que coadunavam uma imbricação, e possível dissolvimento dessas potências, diminuindo as fronteiras entre elas até chegarmos ao trânsito de um corpo que já é sua interioridade e um interno que já é corpo.

Essas abordagens fenomenológicos acerca do corpo, nos fazem deduzir que a vivência da cena com a máscara atualiza a experiência do atuante na sua relação cognitiva e espacial, em contraste a ideia de um corpo receptáculo, que provinha da associação entre ações muito básicas de sua natureza física primária, que o vê na intersecção entre algo que entra e algo que sai, como inspirar e expirar, ingerir e excretar, e, portanto, submisso a uma ideia. Porém, ainda nos resta entender como é possível que nessa ação com a máscara o atuante possa acessar e transitar por seu imagético a fim de criar cognições durante a experiência com o objeto.

Recentemente o americano Mark Johnson, observou uma relação direta entre corpo, ambiente, movimento e cognição, não o separando do todo relacional, mas reinterpretando-o sobre a perspectiva da neurociência, que observa a criação de redes neurais inseridas na constância de atualização processual do corpo em movimento, destacando-se dos estudos fenomenológicos ao propor a formalização metafórica como procedimento adotado pelo cérebro para relacionar o movimento cinético espacial e a cognição. Johnson, em seu trabalho de 1987, afirma que a cognição tem origem na motricidade, e assim, o ambiente, pensado sobre as diversas potências desse conceito espacial, tais como o social, econômico, político e cultural, e não só a geografia relacional imediata (onde o corpo está) como topologia de entendimento, interfere diretamente na relação metafórica cognitiva que um certo indivíduo tem em relação às suas percepções, que seriam levadas para sua fisicalidade, quase como um processo de adaptação e ou resposta em ação a esse ambiente, percebendo, dessa maneira, o ambiente como em fluxo dinâmico de comunicação constante com esse corpo, mesmo quando o corpo não deseja ou não entende imediatamente esse diálogo. Assim sendo, ao corpo seria pedido uma resistência ao ambiente, e a forma encontrada para que isso fosse possível seria a sua 
ação nesse mundo, ligada diretamente à motricidade, e que resultaria em cognição, através de um processo de metaforização interpretativa dessa experiência com o mundo, realizada posteriormente aos atos com e no ambiente relacional.

Essa forma de pensar o corpo se opõe a um pensamento antropocêntrico, que entende o ser humano como destacado do seu ambiente e, por conseguinte, ajustando-o para que pudesse responder diretamente aos desejos e necessidades de sobrevivência, e afirma uma ideia de interação simbólica permanente com a ambiência em que se está inserido, na qual uma ação resultaria em reações virtuais e imagéticas de interpretação dessa vivência com o ambiente. Em vista disso, o corpo já seria como uma máquina cognitiva e auto-poiética cotidiana, visto que interpretaria o ambiente com subjetividades em relações simbólicas. Também por essa perspectiva, notamos a influência decisiva e inscrita das culturas diversas sobre o físico, pois se as culturas realizadas pelas sociedades fazem parte das interrelações, ou modos de estar no mundo desses seres, elas também influenciariam esses corpos e suas sensações ambientais, e assim poderiam ser observadas e contextualizadas por essas determinantes formas de pensar e agir no mundo, que estariam sobre essa perspectivas diretamente relacionadas na fisicalidade do ser. Portanto, um corpo e suas interações historiográficas, inseridos em determinada situação e seus atravessamentos (sócio-políticos e culturais) reagindo às provocações entendidas nessa situação, criaria uma simbolização e interpretação imagética, que lhe resultaria em cognição. Por essa via, a máscara se insere nos atravessamentos processuais da experiência de uma atuante com seu espaço, inferindo certas provocações através de seu universo simbólico. Buscando ganhar uma significância física o objeto pede ao ator que lhe dê um sentido em seu corpo, rompendo sua forma continua e entendida de estar no mundo, deslocando a percepção do atuante para essa experiência imediata de estar outro em sua fisicalidade, sendo então dessa interação, atravessamento e trânsito imagético provocados pelo objeto no ambiente em que o atuante está inserido, que se dá a cognição e as possíveis criações imagéticas que surgem da associação entre essas máximas, corpo e 
máscara, mas de que tipo de associações o corpo realiza perante o atravessamento do objeto?

Helena Katz, em seu estudo sobre o Corpo-Mídia, já observa na pesquisa de Johnson uma forma de entender como se dá a relação física de um corpo em arte com o ambiente, que possibilita que toda e qualquer experiência corporal seja, de alguma forma, uma resistência criada pela motricidade, que se afirma através de filtros cognitivos, associado por esse corpo, e, portanto, uma experiência capaz de acessar o imagético simbólico, que posteriormente seria traduzido em cognição, na percepção e afecção abertas daquele que pratica a vivência artística. Assim, por esse pensamento diminuem-se as fronteiras e toda ação física já seria conhecimento, e, por outro lado, todo conhecimento residiria também no corpo em uma relação de interdependência, porém, não de forma direta e cartesiana de causa e efeito, mas sim de forma residual e processual, na qual o corpo guardaria certa sensação de determinada experiência e poderia acessá-la por rastreamento cognitivo em outro momento experiencial, escolhendo intuitivamente o que acessar, através dos filtros ambientais, que determinariam certa diferenciação na vivência, e pelo acumulo de sensações que estariam determinando sua perspectiva. Dessa maneira, uma experiência resistiria no corpo como imagem, percepção e afeto, a serem relacionados na simbolização da vivência em dependendo da necessidade que o ser notar, consciente ou inconscientemente em suas experiências, em associações perceptivas pelos ambientes em que realiza suas ações motoras e artísticas, que também promoveriam, por esse olhar, novos afectos e perceptos, vivenciando então um limite entre consciência-inconsciência tanto gestual quanto cognitivo.

Essa relação, corpo e cognição, não se aproxima das teorias mecanicistas de causa e efeito, mas interagem com os conceitos de Espinosa sobre a relação isonômica entre corpo, mente e afetos, nessa perspectiva o corpo não é responsável pelas ideias, nem os pensamentos criam fisicalidades, mas ambos se afetam e exprimem o mesmo acontecimento de formas distintas. Espinosa afirma o corpo como uma individualidade, um corpo relacional, que se afeta e é afetado por outros corpos na natureza. Segundo Marilena Chauí ele é "constituído por relações internas e externas com outros corpos e por 
afecções, ou seja, pela capacidade de afetar outros corpos e de ser afetado por eles sem se destruir, o corpo se regenera com eles, assim como lhes dá uma maior capacidade vital (CHAUÍ, 1995, p. 50-51). Para Espinosa o corpo é uma individualidade dinâmica e intercorpórea, que não se define por seus encontros ou entrechoques, mas por relações de composições e decomposição em busca de uma existência no mundo das coisas, que the confere uma exterioridade. Essa aproximação do corpo com o ambiente e a sua inferência direta com a mente possibilita um pensamento sobre a materialidade das afç̧ões e a sua capacidade de criar ideias do corpo para a mente e da mente para o corpo, pois as afecções do corpo são, por esse pensamento, formas de afeto para a mente, ocorrendo em ambos ao concomitantemente.

A influência de Espinosa se verifica na pesquisa de neurolinguística de Mark Johnson, mas suas reflexões organizam o como se daria o trânsito entre mente e corpo, e sua conexão com o ambiente e cultura dos indivíduos, pois para Johnson, a cognição se dá muitas vezes em uma relação metafórica pré-associada com a cultura do indivíduo, em um condicionamento simbólico que entende e experimenta coisas em termos de outra, agindo na construção dessas metáforas que acionariam o sistema sensório-motor, e ao agir, se "abre a possibilidade de fazer ou desfazer o que foi conceituado antes, instaurando novas possibilidades de pensar e mover: corpo, ideias e mundo" (GREINER, 2010:129). É portanto, em uma relação metafórica que o homem infere, através da sua experiência subjetiva no mundo, uma possibilidade de comunicação e conceituação com seu ambiente e as instâncias internas de sua imagética, pois através desse sistema conceitual criado da experimentação do homem no mundo que ele se relaciona, pensa e age, segundo Johnson:

\footnotetext{
"Nossos conceitos estruturam o que percebemos, como nos movemos no mundo e como nos relacionamos com outras pessoas. Nossos sistemas conceituais desempenham assim um papel fundamental em definir nossa realidade cotidiana" (LAKOFF and JOHNSON, 2003 :04).
}

As relações metafóricas sugerem uma simbologia e significância cruzada nas quais, para cada atividade do corpo no mundo, é feita uma leitura cognitiva e 
encadeada de outros fluxos de leituras, assim, quando um sujeito observa e nomeia algo ele o interpreta metaforicamente, influenciado por sua cultura, ante aos outros objetos do mundo, e quando ele age com esse objeto, ele cria uma cognição metafórica da experiência, desenvolvendo por livre associação, por intencionalidade ou por consequência, com seus gestos físicos, uma síntese de sensações vinculadas nesse contato. É o que podemos entender no exemplo delineado por Johnson e Lakoff, em Metaphors We Live By, de 2003, no qual o estudioso entende a significância cruzada para os ocidentais, de ARGUMENTO e GUERRA, que apesar de conterem significações distintas, inferem-se linguisticamente e culturalmente, e por isso, interferem nos modus de ação do ser no ato de argumentar e pensar, como, por exemplo, quando se diz algo como: "ele atacou cada ponto do meu argumento, ele destruiu meus argumentos, se você usar essa estratégia eu vou demolir cada ponto de seu argumento e etc." Nessa exemplificação dos autores, notamos que argumentar e guerrear não se relacionam literalmente, mas sim metaforicamente, utilizando certa lacuna contida na comunicação e substituindo aspectos de um conceito por outro, distinguindo, por essa via, as relações estabelecidas por esse indivíduo com o mundo e suas formas cognitivas associativas, que possibilitam a esse sujeito uma ação de combate ligada ao diálogo. A mesma relação linguística é exemplificada pelos autores com: TEMPO e DINHEIRO, MENTE e MAQUINA etc.

Quando aferimos essa sistemática na cena com a máscara, entendemos mais facilmente como pode acontecer a criação dessa cognição metafórica para o ator em jogo com o objeto, pois ao responder a determinadas provocações na ação com a máscara o ator busca um reflexo em sua experiência sociocultural que possibilite que aquele ser outro simbolizado no objeto aja em correspondência na gestualidade de seu corpo, assim utilizando uma forma por outra, na lacuna interpretativa que a própria máscara lhe oferece, portanto, quando a máscara age é o ator metaforizando a si em um outro, refletindo sua cultura e formas de comunicação na metamorfose desse ser construído. Também na relação de leitura dessas ações físicas notamos a mesma associação metafórica, pois ao mediar a relação espaço-temporal do ator com o observador, a máscara cria uma 
correspondência do mundo que é respondida na ação pelo atuante, sendo assim um atrito na relação espacial desse corpo com o ambiente (inserido o espectador), e enquanto atrito, criaria outras possibilidades de motricidade e gestualidade enquanto viabilizaria uma experimentação cognitiva simbólica tanto no público quanto no corpo em ação, que busca representar algo, e portanto, cria uma ruptura no tecido cotidiano de entendimento e desenvolvimento dinâmico da experiência do atuante, o que capacitaria uma associação, em busca de significância, entre corpo e mente, uma associação que ocorre metaforicamente de uma significação para outra, e, em última instância, realiza o corpo em uma máquina auto-poiética estética, ou, como afirma Mnouschkine, sobre a função do ator: "uma pessoa que metaforiza uma sensação" (WILLIAMS, apud MILLER, 2007:44), em um fluxo em que cada sensação, ou paisagem interna, como a diretora afirma, seria seguida por outra em rupturas descontínuas. Destarte, poderíamos aferir essa significância de irradiação metafórica a qualquer objeto que criasse uma ruptura no tecido cotidiano do atuante, mas a máscara possui esse atributo na sua estrutura simbólica e lacunar, isso é, na sua qualidade de ser um outro tracejado na materialidade de sua arquitetura, indicando, assim, uma alteridade, um mundo a ser descoberto na atividade pelo ator e pelos observadores.

\subsection{Diminuindo as fronteiras entre o Corpo e o imaginário.}

Na vivência com a máscara o espaço entre o ser e o ser mascarado construído, afirma um limite da realização imagética do atuante, ou um impeditivo em que somente se visse um corpo distinto, porém sem trânsito entre um e outro. A pontuação desses fluxos simbólicos, nos parece uma forma de mapa que ajuda o ator a não se perder em sua dinâmica com o objeto, pois a pontuação das ações libera uma clareza sobre cada impulso criativo do ator, possibilitando que uma ação ou gesto vá até seu final e sejam decodificados pela audiência, essa interface das pontuações, são solicitadas aos atores do Soleil por Ariane Mnouschkine, e permitem que a música interna do atuante, desenvolvida na duração do jogo, invada a sua vivência e faça seu corpo dançar. A máscara, vista sob essa perspectiva não 
impulsiona o ator a executar certa tarefa com sua interferência (máscara colada ao rosto), mas sim empurraria o atuante para uma vivência intensiva fora do padrão cotidiano, que poderia fazê-lo encontrar novos territórios subjetivos e ser atravessado por essas experiências, que o induziriam a novas formas imagéticas e a outras cognições metafóricas, como uma música exalada por seu corpo em contato com essa música interna dos seus impulsos criativos, em uma resposta de sensações que poderiam tornar visível o invisível, do que lhe acontece, tornando a experiência com o corpo uma forma de força.

\footnotetext{
"Quando o corpo é levado a experiências de fronteira dele mesmo pode desmoronar padrões conhecidos, desterritorializar-se, e, a partir desse território outro, reterritorializar-se de forma potente, gerando, então, não formas físicas mecânicas, mas formas de forças" (FERRACINI, 2013:29)
}

O termo Formas de Força, foi pensado pelo pesquisador José Gil como formas geradoras de zonas de jogo, e no caso do teatro, em que as potências participantes afetam e são afetadas mutuamente pelo entorno cênico: palco, tempo, espaço, outro ator e também pelos objetos como a máscara. Nessa perspectiva, a máscara conectaria através da criação dessa forma de força, o interno cognitivo e imagético do atuante a sua realização objetiva de uma maneira amplificada em que o acontecimento seria já uma resposta espacial realizado pela gestualidade física e sensorial, um gestoemoção, que possibilitaria uma mudança atmosférica no ambiente vinculado a essa gestualidade, e por outro lado, o espaço se tornaria uma espécie de espaço sensorial afetivo, que promoveria um atravessamento constante das linhas de força criadas na gestualidade do atuante, gerando um corpo dínamo que infere um ritmo e dinâmica ao espaço alterando sua densidade e ao mesmo tempo é afetado por sua percepção dessa atmosfera, essa constante, no trabalho com as máscaras de Mnouschkine, seria realizada com pontuações, para que o corpo conduzisse essa forma de força até o limite, escutasse as alterações provocadas pela ação no espaço antes de adentrar a próxima camada sensível e imagética em um jogo de escuta e resposta aos estímulos criados.

Se pensada como uma facilitadora de formas de força no corpo do atuante, uma máscara não pode ser uma experimentação técnica fixa, mas sim uma 
recriação em atualização constante e pontuada a cada instante na duração desse jogo. Recriada para que não haja uma colagem de sua experiência de ruptura no próprio tecido cotidiano do atuante, o que faria com que as atualizações dessa relação do sensório-cognitivo do ator com a sua própria vivência física se tornassem uma interface já experienciada, participante do continuun do atuante, destarte, a escuta e percepção são pontos fundamentais para que haja certas lacunas por meio das quais se respire a ação e se promova vida no ser mascarado. Essa respiração, no caso do Soleil, é promovida através da pontuação das ações, isso é: haja, escute e reaja, como três pontos interligados e fluidos, mas destacados e pontuados um do outro, o que promove um corpo em uma potência constante de percepção e afecção, como uma forma de força pontuada, para que se possa conduzir o observador por cada paisagem sensível criada pelo ator, e sentida como a exalação de certa música através do corpo para o público.

Por outra via, entendemos que trabalhos técnicos puros podem não prever a reatualização da máscara, mas sim o estudo dos tipos definidos pela tradição clássica, o que é negado na reatualização arquetípica das máscaras proposto por Ariane, que se serve delas para a criação dessas paisagens criativas do ator, como veremos no próximo capítulo. Essa outra forma de mascaramento mais voltada aos tipos fixos, mesmo quando amparada pela pontuação constante no jogo da máscara, traria não mais o desafio constantemente sussurrado pelo objeto, como Mnouschkine pensa, mas sim o aprendizado técnico, que não subentende a perspectiva sobre a constituição corpórea do atuante em dinâmica com a linguagem da máscara, como aqui pesquisamos, mas sim uma abordagem que percebe outro tipo de jogo, mais amparado nos estudos e construções de personagens através dos estudos dos tipos puros, como os da comedia dell'arte. Por outro lado, a permanente reatualização do jogo com a máscara propõe que se observe a porosidade e escuta como primordiais no corpo do ator, entendendo-o, assim como um profissional do afeto, com a capacidade expandida de perceber e ser afetado pelo seu entorno, o que o torna um ser expandido, no sentido de mais conectado e observador desses jogos mínimos que ocorrem no limite estabelecido por essa ruptura desenvolvida na conexão do jogo. Assim, a máscara seria como uma ponte interligando o subjetivo do atuante com a disposição material de 
sua objetividade física. Sobre esse aspecto, a percepção e a afecção estariam interligadas na experimentação do corpo com a máscara e a seleção cognitiva e imagética se daria através dos filtros socioculturais do corpo, que realizariam as metaforizações de novas experiências no fluxo relacional desse corpo com o ambiente.

Essas afecções são possibilitadas quando o corpo percebe algo no seu campo relacional, para Henri Bergson: "perceber consiste em separar, do conjunto dos objetos, a ação possível do meu corpo sobre eles" (BERGSON, 1990:188). Desse ponto de vista, o corpo vivo e o meio circundante participam da mesma realidade e se afetam mutualmente, pois perceber já estaria vinculado a uma ação desse corpo no ambiente, mas aferimos que essa percepção passa pelo filtro sociocultural que o corpo já contém em sua historiografia, e, portanto, ele nomeia e age sobre as coisas materiais que consegue ver ou inventar sobre a perspectiva de sua cultura, pois se a matéria "é o conjunto das imagens, a percepção da matéria não será outra coisa senão a relação dessas imagens com a ação possível do meu corpo" (CARDIM, 2009:64). Podemos dessa maneira entender que perceber algo está relacionado ao conjunto sociocultural, que o indivíduo possui, em expansão constante na duração de sua vida, perceber se incute como a possibilidade de "ter olhos pra ver".

Contudo, são os afectos que conduzem o olhar para aquilo que percebemos. Os afectos estão relacionados com o passado e todas as suas implicações no indivíduo, aquilo que se infiltra enquanto memória no corpo, o que na perspectiva bergsoniana é o que não pode mais agir, mas que empresta a vitalidade do presente para inserir-se em uma sensação e produzir novas percepções. Sobre esse ponto de vista, o que nos afeta também está relacionado com os filtros historiográficos do ser, exercidos pela percepção do indivíduo no mundo, e com as rupturas exercidas pelas pulsões e desejos no campo sensível desse ser que age no mundo.

É do corpo vivo, que produz um pensamento/corpo, como uma presença pulsante do desejo. Do corpo que se vê alterado da sua interação cotidiana consigo e com o seu meio, que podemos entender a relação do que é percebido com o que é afetado. Sem que haja uma pulsão de vida, o corpo pode até ser visto como ferramenta de trabalho para o ator, mas com o 
entendimento que atribuí a ele uma qualidade de dínamo dos pensamentos e da memória, como vimos, o corpo passa a ser o próprio discurso, o próprio ator, a própria materialidade de pulsão do desejo de vida, do vir a ser, do devir, que irrompe em percepções e afecções no campo relacional do jogo cênico.

Observamos então, que, no caso do atuante, sua capacidade criativa estaria relacionada a sua percepção e afecção do ambiente relacional em que está inserido, quanto mais ele percebe e se deixa ser afetado mais ele mergulha em redes imagéticas e criativas que Ihe impulsionam a agir sobre esse mundo percebido, e quanto mais ele age sobre o mundo mais ele o modifica, abrindo novas camadas de percepção e afecção, que gerariam, dessa maneira um certo campo de força e de atratividade. Esses campos de força são então criados quando o corpo age sobre o mundo modificando-o, e assim tenta responder a esse colapso com o que já lhe é familiar, se adaptando a essa nova interface em ação e criando um metaforização cognitiva acerca dessa experiência.

No caso da experiência com máscaras, o objeto se coloca como o estranho, o outro que se interpõem entre a percepção do mundo material do corpo e sua afecção da experiência, essa interface distingue o corpo de seu cotidiano e irrompe outras formas de estar e ser no corpo do atuante. Quando, como no caso do Soleil, essa experiência é alimentada em um fluxo de provocações com outros dispositivos geradores de jogo, (tais como a música, texto etc.) se subverte a ideia de fixidez e permanência dos tipos, elevando a mediação da máscara a um estado de resposta continua e urgente, que gera uma prontidão do corpo em estado de força. Ao mesmo tempo é requisitado um relaxamento do atuante, para a condução específica dessas tensões criadas, dosando, dessa maneira, o campo de tensão do jogo, provocado pela ruptura promovida pela máscara, com o relaxamento do corpo, para responder em ações e gestos, já que sua face, ponto expressivo mais usado do humano, estaria coberta em uma expressão fixa da arquitetura do objeto, e somente seu corpo poderia comunicar as sensações envolvidas na experiência, fazendo com que a expressão no objeto se torne dinâmica e a máscara "ganhe vida". Essa dosagem de tensão e relaxamento possibilita que se crie uma certa musicalidade possível do corpo do atuante, o que é 
requerido por Mnouschkine, quando pede que os atores ouçam suas "músicas interiores".

Entendemos essa música interna como a pulsação entre sons e silêncios, sendo os sons a condução expressiva de determinada tensão através corpo para a realização de uma ação, e o silêncio, como uma pontuação afetiva nas quais o ator recebe e percebe as alterações provocadas por suas ações no mundo. Em fluidez entre tensões e respirações, essa pulsação nos parece capaz de produzir um ritmo conduzido do corpo para a cena, mesmo quando há uma imobilidade na atividade do ator. Quando questionada sobre a música interna, Aline Borsari, atriz do Soleil desde 2014, afirma:

\footnotetext{
"Eu acho que concretamente é rítmico mesmo e que pode estar na minha respiração, pode estar na batida do meu coração, mas é concreto, não é assim eu pensando numa melodia x, "alguma coisa que está lá e mesmo se eu estiver imóvel eu estou sentindo essa pulsação e é incrível como é visível" (BORSARI,2017)
}

Assim essa música interna é capaz de conduzir o corpo, através do jogo, a um atravessamento no qual o atuante nunca sinta-se integralmente relaxado, mas em uma prontidão "porosa", que o deixe incorporar-se física e sensorialmente ao jogo, e produza por essa prática, uma alteração tangível e dilatada do seu corpo, produzindo uma zona de intensidade entre sua percepção e a afecção, o que cria uma forma de força em camadas de interrelações, sobreposições imagéticas e fluxos contínuos de agenciamentos, que engendram uma dramaturgia própria da sua experiência, muito além da dramaturgia textual e mais focada no espanto criado por essa troca com a máscara no ato cênico. Essa troca constante entre corpo e ambiente quando mediada pela máscara produz uma teatralidade imediata, que possibilita uma desterritorialização o corpo levando-o a usar essa pulsão criativa para a perspectiva desse outro contido no objeto, diferenciando a vivência do ponto de vista psicologizante do ator, tornando a experiência uma atividade de si em outro, uma ação de alteridade em um agenciamento gerador de uma corporeidade distinta para o atuante, que já é por si uma alteração no ambiente relacional, em outras palavras, a máscara potencializa o fluxo de afecção do ator e lhe possibilita um desbravar a si no outro, quase como se produzisse no exercício um campo subjétil para o ator. 
O termo subjétil, apesar de dicionarizado na França, era muito pouco usual e apareceu em três momentos na obra de Artaud: 1939,1942 e 1943. Nas cartas em que cita a palavra, Artaud refere-se a ela como um desenho que o traiu e o revelou, talvez confirmando que a partir daquele momento a ordem da escrita e do desenho estavam entrelaçados por uma forma de força que o expulsava da lógica cartesiana e o levava a novos emaranhados de pensamento. Esse termo foi depois desenvolvido por Derrida na sua escrita sobre essa forma que não é um o quê, nem um quem, que está por cima e abaixo e não se deixa definir, mas que ao mesmo tempo cria uma força capaz de fazer sair de si não somente em direção ao outro, mas sim em direção a vários outros contidos no intermezzo do humano.

A afirmação dessa alteridade maior, que refaz o ser em múltiplos e o retira do eu (self), que o define, foi então entendida no corpo por Derrida como a força que o faz sair da lógica existencial, como um paradoxo sem paradoxo, no qual se pudesse quebrar as políticas impressas em uma regulamentação dos corpos através das historiografias e culturas massacrantes dos sistemas nos quais os seres estivessem vivendo. Encontrando, através desse despedaçamento do corpo, uma forma de força que pudesse o tornar uma potência em vida, desenvolvendo uma capacidade maior de afetar e ser afetado, um percepto e um afecto naquele que o busca. Essa "violência" contra o continuum da experiência viva do corpo, nos parece ser um princípio basal de utilização de máscaras no Solei, pois Ariane propõe que através da máscara, o ator se entregue ao subjetivo da sua vivência e revele suas metáforas por meio de seu corpo, sem que, necessariamente, entregue a ele uma forma pré-estabelecida, mas sim o deixando criar através das influências de suas próprias leituras realizadas na duração do jogo mediado pela linguagem da máscara, recriando orientes e arquétipos, e solicitando uma aderência de seu subjetivo ao corpo.

Derrida ainda afirma que o subjétil não pode ser alcançado, já que no momento em que se conseguisse criar essa forma de força, o subjétil já se refaria em novos complexos, e somente a busca eterna por encontrá-lo conseguiria criar uma constância de força, assim, no caso do corpo, seria quase como se ele se desterritorializasse ao mesmo tempo em que já estaria 
eterritoriarizando-se, numa sequenciação que o retira de seu contínuo, ao mesmo tempo em que criaria um novo para que ele pudesse habitar.

Essa busca infinita pelo subjétil no corpo, que criaria zonas de força, processariam nesse corpo midiado um risco que o colocaria em potência de criação e cognição constante, reafirmando um querer ser outrem, que pudesse criar novas formas de estar na percepção do atuante. Segundo Ferracini: "Poderíamos dizer, então, que o corpo-subjétil não age nas leis da física clássica, mas nas percepções e afetações sensoriais singulares tanto do atuador como do receptor" (FERRACINI, 2013:100). Dessa forma, seria possível recriar as sensações imagéticas em micro percepções, que interfeririam no estado de latência física, que se atualiza constantemente. Assim, a interferência do objeto máscara como algo que se coloca no meio dessa relação do corpo-mídia se apresenta como um disparador de novos perceptos e novos afectos que lança esse corpo em uma recriação do seu estar no mundo, uma quebra do continuum em busca desse constante recriar-se. Assim a máscara, criando um ruído para esse corpo em busca de desabitar-se, possibilitaria uma sintonia sensorial entre a cognição e a imagética do atuante, que pronto a responder às solicitações do objeto, criaria uma zona de força em busca de uma subjetilição (associada a busca do subjétil), que, ao contrário da subjetivação, solicitaria um esforço de conexão para que se chegasse a alcançar esse possível subjétil, que já no momento estaria fora do alcance da experiência e assim solicitaria uma atualização constante desse corpo na experiência.

Observamos, portanto, que a multiplicidade de ideias filosóficas acerca do corpo possibilitam entender que o liame possível entre a máscara e o corpo, se faz em detrimento do caminho que se adota para pensar epistemologicamente o suposto interno: não mostrado, subjetivo e imagético do ator, e o suporte físico, como ponto de inflexão desse interno ou como realizador dessas subjetividades requeridas em momento presente, e que, como o corpo percebe e se afeta com a presença da máscara, também é condicionado pelo tratamento técnico requisitado em cada processo artístico. Entretanto, entendemos que a ligação dessas potências (corpo e máscara), requerida por Ariane Mnouschkine no Théâtre du Soliel, se desenvolve pela pulsão do ator em conjunção com as percepções e afecções dele em seu 
processo criativo, e que através da realização do campo experiencial em jogo, a diretora requer que uma forma venha à tona no corpo do ator, uma forma de força, que faça ver uma verdade em sua realização, e entendemos que essa verdade somente é possível através do engajamento do ator na aventura, engajamento psicofísico que the proporciona uma emergência e ruptura dos padrões, e que, mesmo por um momento, pode fazer aparecer um corpo subjétil, um corpo potência , um corpo-máscara.

\subsection{A máscara como mídia}

Se reconhecermos que o corpo, em contato com a máscara, pode originar um corpo subjétil no campo de força da experiência disruptiva da cena, a perspectiva acerca da máscara também deve ser reinterpretada para que possamos entrever como ela se relaciona com esse corpo estudado.

Podemos aferir para a máscara uma certa qualidade de mídia transitiva, como observamos anteriormente, que liga um comunicante material do corpo do atuante a um comunicado subjetivo das sensações incutidas no jogo. Por esse pensamento, observamos que uma mídia seria um meio oco, mas não vago de significados, no qual determinada comunicação pode ser inserida, o mesmo meio que objetiva e define por si só o tipo de comunicação exercida. O meio é a própria mensagem, como diria Marshall Mcluhan ${ }^{3}$, assim, uma fala midiada por um vídeo é inteiramente diferente de uma fala transcrita para um livro, e o que influência frontalmente essa diferença não é puramente o conteúdo, mas sim o próprio meio utilizado para registrar essa fala, influindo inclusive sobre a maneira como a comunicação deve ser feita e a maneira como ela é entendida.

Incluído nos pensamentos do determinismo tecnológico fundado no início do século $X X$, no qual a ideia de que os meios tecnológicos estavam

\footnotetext{
3 Tambéms se atribui a MacLuhan a citação a respeito de uma "Aldeia Global", que relacionava já nos anos 60 a ideia de conexão entre várias mídias. Públicada originalmente em 1967, The Medium is the Massage, causou um grande furor nos meios academicos ao falar que os meios eletrônicos não fossem mais a extênsão de um sentido único, como o livro era do olho ou a linguagem da orelha, mas do sistema nervoso humano em seu conjunto.
} 
influenciando mudanças profundas dentro da sociedade, Mcluhan distinguiu a mídia como o ponto principal para a transmissão de determinada comunicação, muito mais do que um veículo de extensão ou propagação de ideias. Mcluhan ainda diferenciava a mídia entre meio quente e meio frio, qualificando o quente como a saturação de dados ofertada pela mídia para o sistema nervoso humano, o que produziria um menor engajamento do receptor, posto que a maioria dos dados já estariam produzidos a priori e não necessitaria, então, ser preenchida pela interpretação do receptor. Por outro lado, a menor incidência de dados faria com que o interlocutor tivesse que engajar mais sentidos para que produzisse uma significação, sendo que uma menor saturação de dados seria então requerida para que se possibilitasse esse maior engajamento do ser com a comunicação. Podemos exemplificar essa diferenciação com a leitura dos símbolos codificados em um livro, que requer um maior envolvimento do leitor para que se signifique e se interprete as imagens de sua leitura, incidindo nesse ato o olfato, tato e etc., diferentemente da transposição desse mesmo livro para um filme, no qual a imagem já é dada e portanto, o envolvimento do espectador estaria saturado de informações e não necessitaria de criar e interpretar essas imagens pelo seu sistema sensorial, por esse exemplo quando lemos "Iracema, a virgem dos lábios de mel", criamos uma imagem interpretativa dessa personagem de José de Alencar, diferentemente de vê-la projetada em fotogramas de um projetor de cinema, no qual a imagem já está dada e a participação do espectador é menor.

McLuhan considera como meio: "todo objeto, artefato ou dispositivo, que mantém uma relação com o sensório humano (...) todos os artefatos técnicos que prolongam as funções, faculdades ou órgãos humanos" (KAUNE, 2011). Assim, podemos entender como mídia o vestuário, as estradas, maquiagens e etc. E o corpo em sua abordagem material, sensorial e afetiva seria, por esse enfoque, o meio em que atuam essas mídias, provocando diferentes meios de comportamento e gestualidade para responder as provocações exercidas nessa interação, o corpo se conforma, no sentido de ganhar forma, com determinadas atividades comunicativas, estabelecendo posturas e gestualidades específicas para cada experiência. 
Por outro lado, a máscara, pensada sobre esse aspecto da mass media de Marshall Mcluhan, pode ser entendida como o que medeia também esse corpo cheio de símbolos do atuante com o observador, prolongando suas funções e atuando na produção simbólica e gestual de códigos teatralizados pelo público ${ }^{4}$, pois ao se utilizar do objeto como possibilidade de extensão e mediação do seu imaginário para seu corpo, o atuante produz através dela um "texto" a ser lido e interpretado pela plateia, seria ela então também entendida como "o que se superpõe ao actante e ao espaço, enfim todos os sistemas de signos preparados para mediar o ator e o público". (GUINSBURG, 2005: 161).

Porém, como afirma Mcluhan, essa mídia não é vazia de significados, um receptáculo pronto para que se coloque qualquer comunicação, mas sim a própria mensagem, a máscara oferta a linguagem cênica e direciona a leitura do observador, engajando mudanças comportamentais e gestuais em todos os participantes da experiência, que compromete de forma diferencial esses corpos na observação e realização da cena. Assim, quando vemos uma máscara dinamizada pelo corpo do ator, observamos seu corpo se conformar com os códigos (o tipo expresso pela máscara, formas sugeridas por sua arquitetura material e simbólica, dilatação física proposta, etc.) e jogos (as relações com os dispositivos cênicos, como veremos a seguir) próprios desse objeto, diferenciando-se do plano imagético de outras linguagens cênicas, a máscara por si reconduz o olhar do público, através do aceite da expressão estática da máscara como uma expressão fixa animada por essa prática, o que torna a atuação desse ator pautada na materialidade de seu corpo, ou seja, fazendo com que ele represente no físico a gama de emoções da atuação, inferindo sensação sobre a cena, possibilitando que essa face estática ganhe um aspecto de vida para o observador na duração da experiência do jogo.

Se partirmos da explicação de McLuhan sobre a mídia e a conectamos com esses princípio da máscara, concluímos então que ela deveria ser uma mídia

\footnotetext{
${ }^{4}$ Sobre esse aspecto do aceite social, Kaune ainda diz: “(...) toda transformação tecnológica das mídias, transforma o ambiente social e a percepção individual e coletiva." (KAUNE, 2011)
} 
fria para o atuante, pois ela sugere, suspira no ouvido de seu manipulador, o que deveria ser imaginado para dar conta de sua complexidade e completar essa sugestão com sua imagética e sensações através da produção de signos a serem partilhados em sua atuação, caso contrário ela não cumpre a mediação entre corpo e imaginário, mas sim torna-se apenas um objeto imóvel no rosto, pois é na lacuna interpretativa, na não saturação dos atributos sígnicos contidos nos códigos que o atuante pode completar com sua imaginação as sugestões do objeto. Da mesma forma, para o público a máscara também deve ter esse atributo de uma mídia fria, pois ao deslocar a atenção para o corpo do atuante ela sugere que a face estática esteja expressando o que o corpo indica, fazendo, como exemplo, com que um alguém que "chore com rosto de papel, chore por um amor impossível (e que) esse amor (seja)perceptivelmente mais pregnante para nós" (TRIGO, 2010:52), isso porque nosso cérebro completa a partir de uma realidade incompleta. Por outro lado, se houver uma saturação de signos, sem pausas e pontuações, para que se faça ler a imagem, através da máscara, o engajamento sensorial desse atuante e do público não estarão integralmente conectados para que se produza uma relativa interface de leitura desses fluxos simbólicos, impondo assim códigos e tornando a máscara uma mídia quente.

Por outro lado a pesquisa de Corpo-Mídia de Christine Greiner e Helena Katz, elucida a evidência epistemológica de mídia sobre o aspecto do corpo como mídia de si mesmo, em atualizações permanentes com as informações espaciais e contextuais realizadas em sua experiência, que processuando em sua unicidade algo dessas informações as tornaria parte integrante dos aspectos sensório-motores desse corpo, e em contraponto com a extensão dos pensamentos de McLuhan, aqui realizadas, observamos que tanto o corpo se reatualiza em contato com máscara, sendo meio e mídia da experiência, quanto a máscara reinterpreta esse corpo midiando-o. Essa articulação dos pensamentos de Greiner e Katz com os de MacLuhan, contrariaria integralmente a ideia de receptáculo midiático oco que poderia ser sugerida como aspecto de mediação da máscara, mas, ao contrário ao observar que o corpo é uma automídia, que fornece a comunicação em si, que em contato com outra mediação estabelecida pela máscara se reatualiza 
constantemente em fluxos de experiência, inferimos uma negociação constante dos fluxos simbólicos entre o corpo e a máscara, negociação, que tanto interfere na atualização de sensações do corpo em cena, quanto reatualiza a máscara, interferindo na ambiência em que ela está inserida e refletindo uma expressividade friccional entre ambos.

Greiner e Katz também entendem que, não necessariamente, essa comunicação criada no corpo-mídia esteja articulada com a cognição do atuante, ou mesmo com o desejo de comunicar algo, posto que a "cognição e a comunicação não são sinônimos, nem mantém uma relação de causa e efeito" (KATZ, 2010: 09). Assim, o ato de vestir uma máscara poderia sugerir para o corpo certos traços, que não necessariamente conduzam para um desejo de comunicar algo ou um personagem, o ato em si de mascarar-se já sugeriria certas sensações que ficariam virtualmente marcadas no corpo, mesmo quando não se tem o desejo de se chegar a determinado material a ser comunicado ou mesmo expresso através da máscara. A experiência com o objeto já traria para o corpo certo resíduo de informações que seriam processadas no continuun do corpo em cena, em um processo de contaminação que o próprio corpo trataria de assimilar, mesurar ou recusar. Seria assim como duas mídias se regulando, dialogando e se autoalimentando continuamente na duração da experiência com o objeto, e mesmo quando não mais em contato direto do objeto junto ao corpo, ainda trataria de resistir enquanto signos residuais nesse corpo. Logo, se a máscara e o corpo são mídias, entendemos que cada uma em separado já trata de conformar certa significância, mas quando atuam conjuntamente, elas se reinterpretam e se reatualizam em toda a duração da experiência mascarada, sendo assim uma potência corpo com máscara.

Em nossa sociedade em fluxo de comunicação e informação contínuas, o corpo, que opera trocas com esse ambiente está, então, bombardeado desses fluxos constantes, que podem fazê-lo se desabitar de si, perdendo-se nas multiplicidades realizadas em acordos sucessivos entre os mecanismos de produção, armazenamento, transformação e distribuição de informações, tornando-se um instrumento de reprodução ideológica, uma máquina de repetição, que não se atualiza em seu estar espaço-temporal, impossibilitando a transitoriedade emergente de vivências realizadas 
sensorialmente e fisicamente por esse corpo, tornando-o cada vez mais racional enquanto perde algumas de suas capacidades sensíveis.

A máscara, como atividade criativa em aproximação com o corpo, força a um processamento quase imediato dessas experiências anteriormente realizadas pelo indivíduo em resíduos que são redimensionados pela própria fisicalidade em imagens e possíveis respostas em forma de gestualidade para a cena teatral, impelindo o ator a materializar fisicamente uma ação frente a sua historiografia sociocultural, posicionando-se entre as multiplicidades informativas desse contemporâneo, o que a maioria das atividades artísticas realizam em seu ofício, mas com o acréscimo desse ser já sugerido na arquitetura material, que virtualiza a experimentação nesse outro ficcional, livre do ser psicológico do atuante, que lhe permite responder com maior ênfase as provocações do jogo. É claro que essa resposta pode não se dar no imediato da vivência, mas pode se realocar posteriormente no continuum do atuante, assim como afirma Greiner e Katz, que pode assim torná-la em uma virtualidade acessível para a materialidade de sua vivência cotidiana e também na criação e na própria dinâmica virtual de outras experiências criativas.

O corpo no contato com a máscara seria então presentificado na própria ação e não visto como material moldável pela razão apenas, unindo, dessa forma, imagem e corpo em uma experiência em que se colariam as bases subjetivas do atuante tais como: cultura, imaginário e emoções. Por outro lado, estaria o imaginário ganhando uma certa fisicalidade nessa forma de pensamento, pois o trânsito, mesmo que residual dessas imagens subjetivas, faria com que se pudesse diminuir o tempo de resposta da construção física dessas imagens motivando uma liberdade de criação para o atuante e possibilitando a ele que atingisse mais facilitadamente a relação entre o que se quer comunicar e o que se vivência.

Por outro lado, poderíamos entender que os movimentos sensoriais do ator podem ser dificultados pela mediação da máscara, pois ela entende esse outro latente a ser construído na dinâmica e um corpo não poroso em que as afecções e percepções do atuante não atuem no processamento da experiência poderiam levar a uma não transitoriedade nessa mediação, alguns atuantes inclusive preferem a formalização técnica da linguagem para 
suas criações , o que não subentende que não engajem a imaginação nessa criação, mas não possibilitam que haja essa dupla mediação entre o corpo e a linguagem. Essa negociação entre a mídia máscara e a mídia corpo poderia resultar em casos em que: A) o corpo resiste e rejeita a máscara, e entende o objeto como um invasor em seu processo de significação, porém ainda assim a experiência com o objeto deixaria certo resíduo significativo dessa vivência no corpo. B) O corpo entrega-se a máscara, e dessa forma acontece o estado de criação de uma mimese, uma metamorfose na qual os códigos impressos no objeto seguem para o corpo e criam esse outro significante. C) O corpo e a máscara coadunam em simbiose significativa, em que os traços significativos da máscara são ressignificados pelo corpo, que redimensiona sua significação original, criando um uno a partir de sua multiplicidade, que se manifesta como traço de significação expressiva, mesmo quando a máscara não está presentificada na ação.

Esses agenciamentos possibilitam que uma miríade de poéticas se desenvolvam através do corpo do atuante em contato com a máscara, e no caso $A$, observamos que a resistência pode gerar estados para a experiência da cena, e a máscara pode servir de treinamento para o desenvolvimento e criação do ator, porém não resultando em mimese de personagem. No exemplo $B$, a entrega de um corpo que aceite as sugestões da máscara resulta em uma diversidade poética observada nos tipos das linguagens tradicionais de máscara como a Commedia Dell Arte, que possibilita a vivência de certa metamorfose em que o personagem e o ator convivem e por fim, o exemplo C há essa mediação dupla, que determina uma hibridização entre máscara e corpo, que podem ou não resultar em mimese corpórea e podem determinar traços significativos tanto na linguagem da máscara, fomentando o que se chama hoje de mascaramentos contemporâneos, quanto no corpo de atuação, delimitando novos tratamentos como no chamado corpo-máscara.

$\mathrm{Na}$ interface do exemplo $A$, vemos os treinamentos de máscara utilizados desde Jacque Copeau e Jacques Lecoq, com as máscaras de treinamento, tanto a neutra quanto as larvárias, provocando estados que são processados em expressões que não requerem a linguagem da máscara, mas sim um corpo em estado teatral. No exemplo $B$, entendemos as práticas de máscara 
expressiva e meia máscara utilizadas nos teatros tradicionais orientais tais como Nô e Kabuki, as práticas da Commédia Dell Arte e os diversos artistas que realizam, através dessa entrega atoral, as regras e significações de tipificação potente das figuras da máscara, e no exemplo $C$, em que existe uma coadunação mediada entre o atuante e a máscara, a prática de mascaramento, que apesar de conter os elementos originais da máscara, entra em um agenciamento com as possibilidades expressivas do atuante e determinam outras formas de utilização da máscara, como nos trabalhos realizados desde Oscar Schlemmer com as arquiteturas de figurinosmáscara, em que o corpo torna-se em sua totalidade a própria máscara, até os trabalhos atuais de diversos artistas que se utilizam da hibridização da linguagem como advento para suas práticas. Nesse procedimento $C$ de agenciamento encontramos o chamado corpo-máscara, que entende o corpo como aquele que toma a máscara em seus traços significativos, integrandoos e ressignificando-os no agenciamento corporal da experiência da cena. Assim, não se trata de um corpo e uma máscara em separados, mas sim um diálogo pertinente em que resultaria em um amalgamento expressivo entre ambas as mídias.

Podemos inferir, logicamente, que esses casos em separado são apenas de nível analítico pois, em dependendo de cada processo e de cada pensamento acerca do corpo e da linguagem da máscara, muitos desses exemplos são reconduzidos, intercalados e reprocessados, mas a aferição desses agenciamentos nos permite ver o quanto o corpo cede à presença da mediação da máscara ou o quanto o objeto pode depositar camadas significativas sobre esse corpo. Dessa forma, não podemos afirmar que na Commedia Dell'Arte o corpo não se coadune com a máscara, mas podemos observar que nas tradições de criação de tipos dessa linguagem há a requisição de uma mimeses em presença do objeto e portanto, um condicionamento do corpo para que a máscara possa cumprir seu papel metamorfoseante.

A resistência física pode ser lida no bloqueio de certos aspectos simbólicos através de um tensionamento e ou não comunicação com a máscara, quanto mais o corpo cede à mediação do objeto e é afetado em sua manifestação material na cena, mais a linguagem expressiva do objeto ganha vida. Porém, 
podemos entender que esse agenciamento também cria camadas residuais no fluxo da vivência dos observadores, que podem processar essas camadas significativas de cada caso através de suas historicidades socioculturais e também interferir no fluxo de experiência desse contato corpo e máscara, pois o observador, como já estudamos, dimensiona também esse agenciamento mediado através da fluição da cena, atuando como um terceiro mediador.

Dessa forma, ao inferir uma leitura dos fluxos contínuos e transitivos existentes na atuação com a máscara, não podemos englobar todas as possibilidades, já que é da experiência que entendemos a análise, portanto, a máscara, entendida em sua qualidade midiática, ao intermediar o corpo, também pode ser apreendida como uma forma de força que cria rupturas nas percepções sensório-motoras do atuante, que pode gerar graus de tensão e aceitação dessa mediação em seu corpo, gerando, como no caso do mascaramento de Mnouschkinne, que veremos a seguir, essa memória corporal, que rascunha formas geometrizadas no corpo do atuante e registra sensações transitivas entre o interno e o externo, nesse contato/contagio do corpo com o objeto.

\subsection{A criança e o espelho}

Em busca de entender o mascaramento corpo-máscara, tendo em vista o trabalho do Théatre du Soleil, questionarmos inicialmente como o corpo pode reagir no contato com a máscara, contudo, também necessitamos entender quais qualidades e provocações são requeridas pela máscara para o ator, isto é, como ela se realiza como um disparador de sensações, emoções, ações e gestualidade no seu jogo com o corpo, dessa maneira, escolhermos não abordar a multiplicidade de linguagens da máscara e suas poética envolvidas no trabalho do grupo francês, posto que cada máscara confeccionada por Erhard Stiefel, para cada produção do Soleil, contém um universo de referências socioculturais, e portanto, requerem diferentes abordagens fenomenológicas para cada uma em sua especificidade, o que seria uma outra pesquisa. Assim, partimos dos pontos básicos, e portanto, amplamente requisitados por Ariane, independentemente da máscara 
utilizada por cada ator em suas diversas peça. Entretanto, decidimos articular metaforicamente esses traços significativos da relação máscara e corpo, no desafio espectral do espelho que Ihe reivindica que seja decifrada a imagem refletida, e no jogo da criança, que induz a uma outra realidade específica enquanto brinca. A decisão de realizar uma articulação metafórica se justifica na coadunação de uma sistematicidade que nos permita entender um aspecto do conceito em termos de outro, assim como proposto por Mark Johnson na formulação sobre a cognição e a ação do homem no mundo, que nos faz revelar e evidenciar certas particularidades em articulação com diferentes abordagens, o que nos permite mirar mais precisamente em quais das múltiplas perspectivas da máscara estamos ressaltando e problematizando, portanto, realizando um olhar no qual aspectos e conceitos diferentes se complementam e se justapõem para serem entendidos posteriormente na experiência laboratorial do terceiro capítulo A máscara, nessa abordagem, é examinada como um espelho refletindo as imagens internas do atuante, enquanto a atitude do ator perante esse objeto seria a de uma criança, brincando de se revelar e se esconder, para si e para o outro, pois entendemos o jogo com a máscara, e seus qualitativos requeridos ao corpo, numa imbricação significativa entre esses dois signos: espelho e criança, em um revelar/ desvelar em que o atuante em conexão com as regras e códigos propostos pelo objeto flui a experiência no ato de mascarar-se. A opção pelo símbolo da criança para observar a relação do indivíduo com seu próprio corpo, nos permite notar um ser que brinca enquanto aprende, e se distância da perspectiva do "eu sou", para se aproximar da do "eu estou" refletindo-se por conseguinte nessa máscara espelho, deixando que o ambiente e as relações lúdicas apareçam em sua experiência, e nessa prática se descobre como um ser em sua alteridade. Por essa via, a metáfora do espelho é conduzida por essa perspectiva da relação do atuante como criança observando ativamente e não de forma contemplativa sua imagem interna refletida em sua materialidade expressiva. Quando observamos uma imagem refletida em um espelho, estamos observando uma imagem invertida horizontalmente (invertendo esquerda e direita), dependente de certa propagação de energia através da incidência de luminosidade, e que consiste no retorno dessa energia incidente em direção 
à região de onde ela é oriunda, isto é, através de ondas eletromagnéticas uma imagem atinge um espelho que a reflete de volta para aquele corpo que a originou. Esse fenômeno físico de irradiação de energia, converge, então, um ponto de partida e retorno de imagem, ou melhor dizendo, um ponto de confluência no qual a imagem do sujeito refletido convirja de certa maneira com o seu reflexo. No entanto, essa imagem refletida, através desse fenômeno óptico, não coincide diretamente com o seu ponto de origem, tendo assim que ser reagrupada no cérebro do observador para que se possa traduzir o refletido, em um trânsito de signos e símbolos decodificados pelo observador; sendo então o que se vê diferente do que é realmente refletido, mas dependendo efetivamente da participação cognitiva do observador para que se complete como uma imagem aproximada da original.

No fenômeno do mascarar-se, podemos observar um processo análogo, no qual a imaginação do atuante afetada pelo jogo cria esse reflexo transitivo e invertido quando em contato com a máscara, isso porque o objeto serve como ponto de intersecção entre o imaginário do ator e a sua potencialidade física, desempenhando assim como uma função de espelho entre a imaginação e o corpo, que nessa operação atuaria como um reflexo dessa imagem interna, fizicalizando-a e tornando visível as sensações criadas nessa prática com a máscara. Sobre esse ponto de vista, a imagem original à ser irradiada é o criativo do ator que é refletido no seu corpo, entendendo, assim, que o que deve ser materializado é a sua afecção criativa com o ambiente circundante, o que não impede que em alguns processos, o inverso aconteça, isto é, tendo o corpo como disparador do imaginário, entretanto a integração de ambos (corpo e imaginário) forçada pela mediação da máscara parece gerar um moto-contínuo, no qual muitas vezes não conseguimos identificar o que seria reflexo ou imagem interna nesse jogo.

Esse fenômeno nos parece estar associado à incompletude que o objeto máscara, aquilo que encobre certa região do rosto em uma Gestalt fixa, possui na sua arquitetura material e simbólica mesmo, pois, ao sugerir para o atuante certas linhas e traços materiais, contidos objetivamente em seu desenho de uma expressão fixa da face, a máscara pede que ele gere um desenho físico para essa figuração, e assim dinamize-a com esse corpo criado, conferindo certo sentido de vida àquela face. Em sua incompletude 
simbólica, a máscara sugere que o atuante crie uma persona que habite sua arquitetura material, e consequentemente o desenho corporal já dinamizado, elaborado por sua sugestão material através de seu imaginário, para que assim possa habitar esse corpo ficcionalizado, dessa forma é como se a arquitetura material impulsionasse a arquitetura simbólica, em uma busca de completude no corpo do atuante, assim, a face fixa da máscara insinua um corpo e uma persona para o atuante, que ao aceitar essa sugestão produz com ela essa arquitetura dinâmica da máscara em seu físico. Porém, nos parece, que ao acolher as propostas materiais e simbólicas do objeto, 0 atuante leva a sua historiografia sociocultural e a sua capacidade de percepção e afecção também para a arquitetura simbólica da máscara, interpretando-a ao mesmo tempo em que se veste nela, incidindo, dessa forma, a si próprio na máscara enquanto a realiza fisicamente.

Portanto, o próprio processo desse mascaramento já é uma metaforização do ator na máscara, e assim exige que todo seu corpo esteja envolvido na realização desse fingir ser outro, contudo, realizando um reflexo que coincida com as suas imagens internas em seu corpo. Quando não há essa coincidência entre imaginário e o reflexo físico dessas imagens, a máscara torna-se apenas um objeto morto encobrindo parte do rosto do atuante, denunciando que as sensações do ator não foram presentificadas, ou por certa dificuldade imaginativa (do plano simbólico), ou por alguma questão física que dificultou a fluidez entre as partes, evidenciando, dessa forma, uma certa falha comunicativa, entre imaginário e corpo, envolvida nesse ato.

A máscara, entendida como espelho impele o ator à trazer para o campo do jogo as metaforizações possíveis dessa experiência de ser um outro em si próprio, ou ser a si em um outro, em um trânsito simbólico de seu corpo com o objeto. Assim, o espelho contém uma fenomenologia que nos ajuda a entender a imbricação envolvida no jogo com a máscara, pois, poderíamos atribuir certos aspectos dessa arquitetura material do objeto (os traços dos tipos: O velho, a bela, o Arlequim etc.) e de seu jogo de completar (dar corpo a esses traços) ao reflexo, que, como vimos, seria a fisicalização da imagem criada pelos aspectos da arquitetura simbólica e ou imagética (o que é refletido), observando assim uma confluência entre o imaginário e o corpo do atuante, para tanto cada uma dessas partes deve, então, conseguir dinamizar 
a relação espaço-temporal da experiência com a máscara através da gestualidade criada por essa coadunação do imaginário colado ao corpo ou produzido por ele.

Não se trata da divisão clássica de forma e conteúdo, posto que essas máximas são entendidas por nós como imbricadas, coladas uma a outra, não havendo uma dissociação, mas sim de entender que o imagético do atuante deve atuar conjuntamente ao seu físico, não devendo haver um delay entre ambos, fluindo a ação diretamente no presente do presente da atuação com esse objeto, prolongando no corpo a ilusão ou a coerência visual, deixando que os impulsos criativos já tomem forma e que o imagético corresponda ao expresso corporalmente.

A máscara teria, por conseguinte, essa qualidade de servir como um meio transitivo espectral para o imaginário gerado durante essa experiênciacontágio do intérprete, possibilitando que essa vivência possibilite a diminuição das interferências externas do jogo e dessa forma o propele a utilizar todo seu corpo, impulsos e energia em um pacto psicofísico que torna o corpo expressivo, e o engaja na dinamização dessa face estática, ou, por outro lado, torna orgânica sua relação física junto ao objeto que cobre seu rosto, utilizando todo o necessário para que essa ação se realize, sem contudo deixar de empregar-se internamente no ato e, com essa equação, extrair uma significância desse contato fluido entre o objeto e o atuante.

Essa organicidade compreende esse fluxo experiencial do contato com a máscara, que emana certa coerência das ações e gestos no ator, através da sistematização complexa dos elementos técnicos elaborados pelo intérprete. Sendo assim, o termo orgânico, nesse caso, compreende tanto a competência técnica do atuante, quanto a sensação de verdade provinda de seu engajamento psicomotor com as pulsões realizadas durante a experiência do jogo, empregando, portanto, essa impressão de verdade possibilitada na organização desses sistemas (corpo e imaginação).

Sem que haja uma pulsão, uma forma de potência de vida, a máscara não teria o que refletir para o corpo, e, portanto, ele se apresentaria esvaziado, Ariane nos fala: "A lei mais misteriosa talvez seja a que rege o mistério que há entre o interno e o externo, entre o estado, ou o sentimento, como diz Jouvet, e a forma. Como dar forma a uma paixão? Como exteriorizar sem cair 
na exterioridade" (FERAL, 2010:70). São os estados comprometidos na duração da experiência, que impulsionam um corpo poroso a responder e exteriorizar essas imagens internas, o comprometimento com a atividade lúdica extrai pulsões criativas no ator, que o realizam como essa criança curiosa em busca de apreender-se, como estudamos.

Assim, é da emoção provinda da ação em cena e não do sentimento, subjetivo e entranhado no atuante, que deve emergir o teatral desenvolvido na sua relação com a máscara, fazendo emergir um extraordinário (fora do comum), no mergulho em suas sensações, na sua capacidade de se emocionar com elas, e na sua incorporação emocional na constituição material do jogo, sendo assim uma transposição metafórica de si na empregada na persona da máscara, contrapondo-se a uma atuação realista psicologizada, pois quanto mais o atuante se prestar ao jogo e as infinitas possibilidades envolvidas criativamente nessa relação com o objeto máscara, mais ele estará próximo da brincadeira da criança, deixando que seu imaginário domine cada vez mais essa relação espectral do espelho, que brinca com o que se vê e o que não conseguimos observar nesse trânsito simbólico com seu corpo. Quanto mais o atuante permite que a máscara brinque em seu corpo, mais ela possibilita que ele esteja outrem, teça novos mundos imaginados e o leva a embarcar através dessa brincadeira em seu afetivo, se realizando dessa maneira como uma força potencial de criação atoral na cena. Se desvinculando das amarras psicológicas que podem the retirar certa força criativa, e se associando as suas "aparições" ou transposições desse imaginário, criadas no contato com a máscara, pois “(...) por definição, o teatro, a arte, é transposição ou transfiguração! Um pintor faz uma pintura de uma maçã, e não é uma maçã. (...) A cena é um espaço de aparições" (MNOUSCHKINE, 2011, p.60).

Essa tênue relação entre o objeto e aquele que se contamina com ele desenvolve-se pelo acolhimento das regras e codificações pré-estabelecidas na vivência do jogo como "uma imensa pulsão de vida, um impulso vertiginoso" (GAULIER, 2016, p 65), assim como uma criança, que brinca de ser um fantasma e se comporta como imagina ser um fantasma embaixo de um lençol, inventando um corpo dinamizado para esse ser e acreditando, acima de tudo, que é esse fantasma, enquanto um observador aceita esses 
códigos e joga conjuntamente com a criança, através da qualidade própria do humano de ficcionalizar ou de teatralizar, esse olhar de fora do jogo é de máxima importância para que haja esse mergulho do atuante na máscara, como veremos mais adiante.

O poeta Douglas Diegues, em artigo publicado sobre a poesia de Manoel de Barros, afirmou: "Escrever com o corpo é como escrever com a infância do corpo, as sensações primeiras: os primeiros cheiros, as primeiras cores, os primeiros sabores, as primeiras texturas os primeiros ruídos, as primeiras alegrias" (DIEGUES, 2016: 219). Não deixa de ser similar o que acontece com o jogo de máscaras: uma escritura realizada com o corpo todo em pulsão de vida do atuante. Dessa forma, essa vivência contida nesse mascaramento proporciona que $o$ jogo crie para esse atuante essas outras realidades de seu imaginário, podendo contribuir para que ele possa criar uma organicidade no fluxo de experiência com a máscara, materializando em seu corpo sua subjetividade criativa.

A competência de imbrincar-se inteiramente no jogo, seria como uma ação não discursiva, naturalmente emanada na fina ligação entre os movimentos, ações e reações, em uma atuação na qual o ator procurasse estabelecer o presente como o tempo único dessa sua experiência em cena, e não o pensar racional sobre ele, que implicaria em um comprometimento de sua imaginação no ato de mascarar-se, pois o levaria a tentar entender o acontecimento, deixando muitas vezes de agir e reagir através de seu corpo aos impulsos realizados na vivência da cena. Essa ação física, em resposta ao ambiente da cena, deve ser assim a mais direta e colada a sua imaginação possível, necessitando, dessa atitude criança, que o permita brincar com suas imagens, e as reflita na máscara espelho na potência do instante da vivência em jogo e em resposta a ele.

Segundo Gadamer, a vivência é algo que "é trazida para fora da continuidade da vida, permanecendo ao mesmo tempo referida ao todo da própria vida (...) $\mathrm{Na}$ medida em que a vivência fica integrada ao todo da vida, esse todo se transforma também presente nela" (GADAMER, 2005: 116) Assim observada, a vivência atualiza a própria experiência do momento, posto que recria o instante em novos fluxos potenciais que engaja seu participante numa presentificação e o coloca em um "risco" contínuo de jogo que se reconfigura 
a cada instante, possibilitando ainda recriar o continuum daqueles que o experienciam, através da potência do momento da vivência. Por outro lado, Larossa Bondia define a experiência por sua passividade, por sua recepção, por sua disponibilidade e por sua abertura no fluxo cotidiano do atuante, definindo-a como uma passividade feita de paixão, paciência, atenção, uma abertura essencial. Contrapondo-se ao conceito de Gadamer pelo recebimento apaixonado da experiência, o conceito de Bondia, nos remete a um aceite e entrega aos fluxos experienciais da vivência que são desenvolvidos no contato com o jogo. Porém, se observarmos esses estudos acerca da vivência do ponto de vista da prática com a máscara, entendemos que a proposta de Gadamer de uma ruptura com o cotinuum nos aproxima da intenção criança, estudada anteriormente, na qual o ator se investe das pulsões criativas para adentrar o universo espectral da máscara, essa intenção mais apaixonada da experiência torna a própria metáfora do espelho contundente, pois seria preciso adentrar esse espaço escuro e lacunar da máscara para que se pudesse descobrir esse outro a ser construído no corpo em uma atitude vertiginosa de entrega à vivência. Se observamos a conceituação de Bondia, entendemos a prática com a máscara vinculada a um aprendizado mais generoso, mas não por isso menos apaixonado, no qual a vivência é, independente da entrega do participante, e a ele compete receber e se deixar levar no fluxo de sua permanência com o objeto para que ela possa inferir esse outro em seu corpo, esse pensamento de Bondia eleva a vivência com a máscara a um status potencial, que arrasta o atuante para adentrar esse outro construído. Dessa forma, no caso de Gadamer a potência se realiza pelo desejo criativo do ator frente ao objeto, enquanto que no caso de Bondia é a própria experimentação do jogo, que possui essa força impulsionadora.

Talvez seja nesses fluxos potenciais entre uma passividade apaixonada (das regras do jogo) e de uma ruptura quase violenta do cotidiano do atuante, frente à solicitação do objeto, que o sujeito da ação possa se agarrar em busca de responder às solicitações requeridas durante o jogo em uma prontidão e escuta que o desnuda, o revela para o outro. 
Com a fama de esconder, proteger ("uma pessoa sente-se como no interior de um observatório" donde se pode ver sem ser visto) a máscara desmascara, revela. Faz mergulhar aquele que a usa no seu eu verdadeiro, obriga-o a abandonar a sua fachada habitual. Desconstrói os seus condicionamentos factícios, põe-no a nu. Trabalhar sob máscara ou analisar este trabalho, leva a explorar cada vez mais profundamente o ser humano, nas suas pulsões mais secretas. Tudo o que a sociedade inibe, a máscara fá-lo ressurgir. (ASLAN, 1999:283)

Portanto, por essas observações da experiência, o atuante se coloca entre uma potência de escuta passiva e uma ação ativa frente às problematizações que o próprio objeto oferta na vivência, e assim possibilita essa dinâmica da brincadeira da criança na qual se mostra enquanto se esconde.

Contudo, sem que aconteça esse outro olhar que aceita os códigos criados, não nos parece que a máscara possa alcançar toda sua plenitude do jogo da criança que faz com que ela dance, flua e se presentifique no corpo do seu manipulador, pois a criança em seu jogo brinca para um alguém, mesmo que imaginário, que the confere uma validação de suas histórias.

A "tomada de papel", estudada também pela Sociologia, na teoria da Interação Social de Goffman, observa que: "Tomar a atitude de um outro é um mecanismo que se baseia primeiramente na resposta do outro a nosso gesto." (HORTA-NUNES, 2005:59), esse ponto de vista entendido nas relações já ficcionalizadas dos entes sociais, empreende a importância do outro para que se cumpra certa mudança comportamental e gestual pelo atuante desempenhado certo papel dentro das sociedades e quando aplicada na relação teatral, revela a capacidade de aceite desses signos pelo observador e também a possibilidade de ficcionalização desse que observa e entende a sua capacidade de ler o mundo em cruzamento com essas suas vivências, bagagem cultural, capacidade de abstração e entendimento do jogo proposto entre outras. É como um qualitativo entendido no humano como teatralidade, termo que designa uma "qualidade quase universal e presente no homem antes de todo ato propriamente estético. É o gosto pelo travestimento, o prazer de criar a ilusão, projetar simulacros de si e do real em direção ao outro" (FÉRAL, 2015, p.88). Essa teatralidade entende então que a máscara cumpriu seu ciclo começando como objeto, sugerindo um outrem para o atuante que ressignifica seu corpo deixando que a máscara dance e flua livremente em si e possibilitando criar, através de seu 
imaginário, esses outros seres e realidades que, finalmente, são aceitos pela audiência como um outro ser, mascarado, mas também como uma verdade emanada das pulsões imagéticas do ator mediadas pela máscara e irradiadas para o seu corpo, formando assim um jogo triangular entre o atuante e o objeto. Esse aceite parece se dar, como afirma Isa Trigo, através do cérebro que tende a englobar e aceitar como verdadeiro tudo o que tiver coerência visual, isso porque nosso cérebro completa, criando esse novo mundo para nós a partir de uma realidade incompleta, pois "nossa visão é criadora", aceitando assim que uma face estática pareça ganhar outras expressões através da dinamização física do ator e possa parecer essa outra persona vivendo em nossa frente.

Essa triangulação entende os símbolos metaforizados na gestualidade desse ator como possibilidades de revelação: do atuante com a máscara para si próprio, e do observador para com esses códigos criados no corpo desse ator pela máscara. Assim, podemos observar que esses qualitativos de espelho e de criança, que a própria máscara oferece para o interprete em seu jogo, realiza-se quando o objeto cria uma ponte entre o imaginário do ator e seu corpo, no caso do espelho, tornando-se um meio pelo qual ele consiga dar forma, para que seu imagético criativo alcance seu corpo, e ao mesmo tempo, possibilite uma potência relacional para com um observador na fluidez com a qual ele cria teatralidades, deixando que as metáforas criadas na vivência dancem em seu corpo. Dessa forma, a máscara torna-se uma mídia relacional entre o corpo do atuante e sua potência criativa, que inclui sua capacidade de percepção e afecção, direcionada a ele próprio e ao observador, ligada a sua historiografia sociocultural e a entrega curiosa e apaixonada ao jogo, o que qualifica essa atitude desse ator frente a máscara com um impulso da criança observando-se nesse espelho e se reconhecendo nele. 


\section{Capitulo 2. O dentro e o fora: O corpo-máscara no Théâtre du Soleil e sua relação com os mascaramentos contemporâneos.}

Se o rosto está escondido, o corpo do ator torna-se um rosto inteiro, expressando a distância o que o rosto verdadeiro expressa em close up" Jean Cocteau

Podemos afirmar que no teatro existem muitas formas, muitas maneiras de criar e ressignificar o sujeito na cena, mas toda vez que um corpo atuante está posto na fenomenologia do ato da cena, independente de com a perspectiva de criação de seres ficcionais ou de uma ação performativa, o que vemos é um signo, representante ou atuante, no presente do presente do ator, e assim, um signo que ao relacionar um significante e um significado, algo preparado para o ato, assume uma coloração distinta, como um involucro do qual emerge um corpo em arte, e esse corpo em arte pode ser visto como uma máscara. Segundo Stephen Brodt, para Ariane Mnouschkine, "No teatro todo o corpo é máscara" 5

O objeto e o corpo guardam certa intimidade e particularidades que convergem para uma criação gestual única para o ator, pois quando a máscara e corpo conseguem entrar em uma relação dialógica e potencial, o que vemos é a auto-revelação do ator, através de seu corpo, em forma de ação dinâmica, em um jogo entre ele e aquilo que ele quer significar, um jogo não de formas, mas de agenciamentos e impermanências em que uma mediação dupla acontece no ato de se mascarar, como vimos no capítulo anterior.

O incerto, o não fixo, são princípios muito caros ao jogo de atores, tanto com a máscara quanto nas técnicas em que o objeto não é requerido, e que na prática do Théâtre du Soleil é uma das únicas certezas, tanto de procedimentos que visem uma metodologia, já que a multiplicidade de técnicas é importante a Ariane, quanto na linguagem poética de seus espetáculos. Para o ator do Soleil é importante que ele "Imagine-se (...)

\footnotetext{
${ }^{5}$ Entrevista concedida por Stephen Brodt, no dia 10 de Dezembro de 2016, da Amok Teatro, que participou do circulo Les Atrides. Brodt fala sobre a máscara do ponto de vista pedagógico em que atua para desenvolver a relação do material psico-físico do ator com seu gestual, segundo Brodt, a diretora entendia a máscara como uma ferramenta de pedagogia, uma ferramenta de atores.
} 
prestes a embarcar em uma aventura teatral que irá lhe levar para territórios teatrais desconhecidos, onde o princípio de criação teatral não está sempre claro" (MILLER, 2007:123). No entanto, para Ariane o princípio mínimo para o teatro é o ator, e a didática entendida pela diretora para esse ator é a máscara, talvez até como uma costura possível da multiplicidade intercultural $^{6}$, pois os atores do Soleil são oriundos de diversos países e culturas e, assim, oferecem uma enorme diversidade de pensamentos e também de imaginários fundados em suas culturas maternas. Para a diretora, essa diversidade aponta para uma riqueza de possibilidades estéticas, além de uma potente abordagem política representada pelos arquétipos humanos contidos nas máscaras e na alteridade do "ser outro" que orienta aquele que a utiliza e torna, no caso do Soleil, um teatro político na medida de um teatro coral, representante de uma comunidade especifica e seus arquétipos, sendo o ator e a historiografia inscrita em seu corpo a própria materialidade de sua cultura que, posta em jogos com a máscara, realizam e fazem ver suas subjetividades, dificilmente representáveis isoladamente.

Porém, apesar de utilizar a máscara como catalizador das interioridades dos atores e como ferramenta de jogos, Mnouschkine não afirma um teatro de máscaras, no sentido tradicional da Commedia Dell'Arte, das peças de Goldoni ou mesmo das tradições balinesas. Ariane entende que a influência da máscara sobre o corpo cria formas, figuras e signos que possibilita a inscrição desse corpo no espaço através de gestos, mas conduzindo o ator sempre para a linguagem teatral, pois "com a máscara, todas as leis do teatro andam juntas. Você não pode escapar delas" (Miller, 2007:38); todavia, muitas vezes ela se serve da máscara durante os treinamentos e procedimentos de criação de cenas, mas a retira da face dos atuantes na nos espetáculos, para que seus rastros fiquem inscritos no corpo expressivo, possibilitando que o ator "desenhe" com seu imaginário e sensibilidade

\footnotetext{
${ }^{6} \mathrm{O}$ termo interculturalismo foi utilizado por Patrice Pavis em suas pesquisas acerca das abordagens cênicas do mundo globalizado, em que as culturas poderiam se conectar e se mixar em encenações em que :"tanto na sua temática quanto na forma de interpretação e encenação, apela para elementos que pertencem, pelo menos em sua origem, à culturas diferentes" (PAVIS, 2010:418).

O conceito foi analisado por Pavis frente a diferentes espetáculos, em especial em A Indiada, espetáculo do Théatre du Soleil de 1987.
} 
abertos ao acontecimento do jogo, e assim crie novas máscaras na vivência, conferindo outros sentidos a Pantalones, Arlequins, Dotores e Barongs Landung, fazendo com que esses tipos sejam então refeitos para o público contemporâneo, reatualizados, em comunhão com a plateia de seu tempo, e assim ressignificando a máscara, em seus arquétipos originais em recriações contemporâneas, que através desse procedimento de atualização dos tipos e ausência do objeto na cena, produz um teatro de "máscara sem máscara", em uma forma de mascaramento contemporâneo.

Os tipos ressignificados nos processos de Ariane emergem em formas físicas nos jogos de cena conduzidos em camadas de provocações feitas pela diretora e respondidas em um rejogo pelos atuantes. Foi a partir de Les Clowns que os dispositivos de jogo e improvisação foram protagonistas no trabalho de criação do Soleil, e também o primeiro em que a máscara tomou a frente da cena usadas como recurso de criação poética em oposição ao naturalismo da atuação. Segundo a diretora:

\footnotetext{
Nosso trabalho sobre Les Clowns, foi, primeiramente, um esforço para melhorar o trabalho de atuação, nos libertar do psicologismo, do naturalismo e de tudo que existia em nós de muito cotidiano(...) Nosso trabalho sobre Les Clowns, é uma vontade clara de dar a cada ator sua plena capacidade criadora, de deixa-lo inventar livremente seu "personagem" e de permitir que ele se descobrisse pela improvisação" (MNOUSCHKINE apud BABLET, 1979: 197)
}

Em L'Âge D’Or, de 1975, as máscaras da Commedia Dellarte e as maquiagens-máscaras do teatro Chinês foram utilizados como linguagem na cena do espetáculo, e a improvisação e jogo foram os dispositivos relacionais nos quais Ariane continuou se apoiando para que o ator pudesse fugir do psicologismo, ao mesmo tempo em que coletivamente criava a dramaturgia do espetáculo, possibilitando que o ator pudesse responder com seu imaginário a busca da interconexão cultural que reinventava os arquétipos da Commedia dell'arte com a influência do kyogen (peças cômicas realizadas nos intervalos dos espetáculos Nô) trazendo para o público da época o diálogo com a clássica comédia francesa, agora atualizada pelo imaginário 
dos atuantes e da diretora, que tentava redescobri-la ${ }^{7}$, trazendo para o grupo a linguagem da máscara como princípio norteador e didático do trabalho do ator. Articulando um Oriente-referenciado ${ }^{8}$ ao ocidente, com uma dramaturgia pautada pela construção coletiva e conectada aos teatros populares, L'Âge Dôr pode ser vista como uma ponte intercultural, que conectou procedimentos clássicos a temas contemporâneos, ao mesmo tempo em que ligava esses procedimentos à historiografia física dos atores de sua época e como consequência, produzia camadas significativas que indicavam, nas palavras da diretora, uma poética de reinvenção de regras de atuação:

Nós não ressuscitamos formas teatrais passadas, Commedia dell'arte ou teatro chinês. Nós queremos reinventar regras de atuação que revelem a realidade cotidiana mostrando-a não de maneira familiar e imutável, mas encantadora e transformável (Programa do espetáculo L’âge $D^{`}$ ’or apud DUSIGNE,2013:21)

A renovação de formas clássicas para os temas e tipos de um teatro mais contemporâneo emergia da necessidade de Mnousckine de realizar um teatro absoluto, que representasse a história, a sociedade e a política, atravessando a vida dos homens ${ }^{9}$, e assim a necessidade de um ator que pudesse responder potencialmente a esse teatro através de seu corpo e de sua imaginação interconectados no ato do jogo. Essa busca de reinvenção de formas de atuação por meio dos clássicos, ao mesmo tempo em que indica uma pesquisa contemporânea da diretora, também a interliga com as pesquisas teatrais do início do século $X X$, época em que a retomada dos estudos do corpo influenciou o fazer teatral e o surgimento de novas pedagogias cênicas.

\footnotetext{
${ }^{7}$ Sobre a abordagem da Commedia dell arte, Ariane afirma "Nós não conhecíamos muito sobre a Commedia Dell'arte. Nós não quisemos nem copiar, nem reconstruir essa forma antiga, nós tentamos redescobri-la, reinventá-la. Nós sabíamos somente que Arlequim representava alguma coisa de essencial que na sua época era compreendido e que nós não deveríamos tentar nos inspirar hoje naquela escola, sem saber nada da atuação que era praticada (ASLAN,1985)

${ }^{8}$ O termo Oriente-referenciado foi dado pela pesquisadora Françoi Quillet para descrever a "inspiração e recriação oriental" nos procedimentos e cenas do Soleil, a própria Ariane afirma que reinventou as tradições orientais em seu teatro, apesar de seus atores serem instrumentalizados por procedimentos como Kabuki, Buranku e etc.

${ }^{9}$ Sobre esse desejo, Mnouschkine fala: "Queria-se chegar aonde não se podia, ao teatro absoluto, à epopeia do presente, à revolução do momento presente. Entrar, ao mesmo tempo, na sociedade, na história, na politica e na vida humana. Representar tudo isso, tocar na própria vida, acordar, despertar, revelar, transformar. Era demais" (PASCAUD,2011:140)
} 
Na verdade, segundo Agambem, as sociedades ocidentais no final do século XIX haviam perdido em definitivo seus gestos, pois a burguesia que estava poucos decênios antes ainda solidamente em posse dos seus símbolos, naquele momento, era vitimada pela interioridade e se consignava a psicologia, e no início do século $X X$, havia uma tentativa dos artistas e filósofos de recuperar os "gestos perdidos", isso é, de trazer para fora a materialidade daquilo que Ihes estava escapando em detrimento dessa psicologização extremada e das forças imperativas do poder sobre os corpos. A máscara, como disparadora de gestualidade que é, foi então recuperada por artistas que se comprometiam com essa busca de retomada do gesto e se afastavam da linguagem teatral romântica, das divas e da psicologia do realismo. É importante entender, sobre esse contexto, que o gesto caracterizasse, segundo Agambem, por pertencer a esfera da ação, se distinguindo do agir (agere) e do fazer (facere), por nele não se produzir, nem se agir enquanto indivíduo, mas sim suportar a ação, o que estaria na esfera do ethos. O gesto é um meio sem fim, que não o busca nem o deseja, é a exibição de uma medialidade, o tornar visível um meio como tal, uma comunicação de uma comunicabilidade, um "mostrar aquilo que não pode ser dito" (AGAMBEM, 2008: 09) e portanto é o ser em si, sem psicologia, sem explicações. Essa reflexão do filósofo italiano sobre o gesto nos ajuda a entender como o teatro reagiu a essa busca por meio da máscara, que é em si o território do gesto, e como as buscas, aproximações e deslocamentos de uma materialidade física na cena, em comunhão com as descobertas distópicas de dispositivos geradores de novos procedimentos, como os dispositivos tecnológicos, que foram engendrando o que chamamos de mascaramento contemporâneo, ao mesmo tempo em que, por resposta a esse deslocamento material, aproximava ou afastava o corpo do ator como centro gerador da cena, originando outras espacialidades e consequentemente novas dramaturgias.

Essas novas interfaces de utilização da máscara começa no início do século $\mathrm{XX}$, quando o objeto foi redescoberto como ferramenta pedagógica para a retomada de um ator popular, capaz de através de seu corpo trazer o seu imaginário e cognição para a cena, negando o teatro romântico e psicológico e afirmando uma cena que fizesse retornar para as grandes massas os 
clássicos teatrais, como as tragédias gregas e Shakespeare. A máscara foi utilizada como instrumental pedagógico que levava à negação da consciência psicológica de si mesmo no momento da atuação, para que se pudesse viver na identidade de um estranho, mantendo-se constantemente vinculado a uma zona de reconhecimento no presente da vivência do jogo, o que lança certo campo de tensão sobre a dramaturgia ao colocar o corpo do atuante como centro gerador do acontecimento, criando intensidades entre diferentes elementos, tais como: corpo e texto, corpo e música, gesto e visualidades e etc. ; gerando nesse entrechoque uma dramaturgia atoral, bem como uma dramaturgia musical, visual e etc.

Artistas como: Edward Gordon Craig, Jacques Copeau, Ethiene Decroux e Jacques Lecoq, foram influentes nesse processo, e suas escolas responsáveis pela formação e influência de diversos artistas que buscavam a essa poética ${ }^{10}$.

Ariane, que frequentou a Ecole Internationel de Lecoq, atribui o seu olhar para o corpo do ator como referência dos seus aprendizados com o mestre:

"Lecoq entendia perfeitamente para que serve um corpo. Antes de Lecoq começar a dar aulas na França, ainda achávamos que os únicos instrumentos para o ator eram a memória, a voz e as palavras. Graças a ele, percebemos que o corpo era a ferramenta primordial." (PASCAUD, 2005: 29),

Lecoq foi o responsável por muito da ampliação didática da utilização das máscaras na formação do atuante contemporâneo através da sua escola internacional. Para Lecoq, o ser é formado por três máscaras: aquela que pensamos ser, aquela que realmente somos e aquela que nos é comum, o que relaciona a materialidade física a certa dinâmica transcendental dos estudos de Jung e seus arquétipos, mas para que se pudesse achar esse

\footnotetext{
${ }^{10}$ A influência do Simbolismo defendido por Gordon Craig no conceito da Ubermarionete e em sua pedagogia aplicada na sua escola, a Arena Goldoni, em Florença, que buscava a formação de um ator "total", foi recebida por Jacques Copeau, que a utilizou no Vleux Colombier, em Paris, em busca da formação de um novo ator que pudesse atender a seu tempo, privilegiando o trabalho físico e os jogos lúdicos da infância do atuante, em detrimento de uma psicologia, "sua meta consistia em preparar o instrumento do ator, refinar sua expressão, tornando-o apto a servir tanto a moderna tragédia quanto a nova comédia de seu tempo" (DANI, 1990: 85), essa mesma busca foi posteriormente transmitida por Decroux, Lecoq e desse último através da sua Ecole International, para Ariane Mnsouchkine, passando por uma diversidade de pensamentos acerca da máscara e de sua fricção com o corpo.
} 
ponto de convergência entre o eu e o outro, espaço da alteridade da própria linguagem com máscara, deveria experienciar o estado neutro, que faz com que o atuante mergulhe no universo da criança e sua pulsão criativa, que enquanto descobre o mundo também descobre a si mesmo.

A máscara em Lecoq tem suas influências no Nô e na sua consequente referência do mimismo, ou seja, das forças atuantes da natureza sobre o homem. É dessa influência que se destacam os ensinamentos até hoje praticados na escola de Lecoq: "Tudo se move", essa relação do homem com as energias pulsantes e transcendentais que 0 atravessam e afirmam o ser no meio da ação universal, querendo ele ou não participar de tal ato, e que a ele (anthropos) confere um ritmo-mimismo na tentativa de responder a essas ações exercidas sobre ele, o faz responder rejogando com ações e gestos na constante de provocações ambientais e em fluxos que recebe. Dessa forma, um dos principais elementos de entendimento da pedagogia de Lecoq está nesse rejogar: Algo afeta o ser e uma vez que tenha consciência dessa afetação, ele rejoga no fluxo experiencial da cena com máscara. Esse rejeu é um desaprender constante, uma prontidão da criança, um constante refazer. Nesse entendimento, Lecoq ensina que tudo flui em você e apesar de você, todas as coisas fluem e fluímos com elas, e é com essa influência, e apesar dela, que o homem passa então a ser observado como aquele que cria cognições com todo o seu corpo.

As pesquisas a respeito do corpo como suporte e síntese de um mundo, resultaram, em um entendimento de uma inteligência gestual, como algo em processo e residual, que busca o equilíbrio na fisicalidade do humano e se manifesta em sua gestualidade, o rejogar do corpo junto ao mundo permitiria certa concretude física e espiritual nas reações do humano ante as ações ambientais em que ele está submetido (enviromment), assim a realidade é que Joga (In-Prime) algo ao ser, e ele Ex-Prime (joga de volta), e essa dinâmica se observa através da relação do mimismo-cinético, que busca o equilíbrio (direita-esquerda, frente-trás, alto-baixo), e o não equilíbrio dessas forças resultaria em corpo algebrose (morto), por essa investigação o atuante ao colocar a máscara equilibraria essa relação e em contato com as energias circundantes voltaria ao estado potente e curioso da criança. 
Dessa maneira, a perspectiva da transcendência holística de influência oriental, fora aplicada nessa abordagem do corpo na Europa no início do século $X X$, e produziu uma busca pela reapropriação desse gestual humano perdido pelo efeito dos estudos e aplicações exacerbados da psicologia sobre aquelas sociedades e reaproximou, no teatro, o físico do atuante da objetividade da forma expressiva, como material presencial que emerge do contato do ator com o ambiente da cena. Nas pesquisas teatrais o objeto é o responsável por mediar esse contato criando outras zonas de turbulências que obrigam o atuante a reagir imediatamente com sua gestualidade no fluxo de cena. O princípio do corpo em rejeu nos ajuda a entender como as máscaras podem alcançar uma transcendência em contato com as ambiências (dispositivos de cena, tais como cenografia, música, figurinos e etc.) criadas no Soleil para gerar um estado imagético ativo no ator, que são potencializados pela condução da diretora.

Essa visão holística foi de grande influência na didática de Lecoq, e consequentemente ganhou uma preponderância na condução dos jogo e dos pensamentos de Ariane, pois foi através da pedagogia de Lecoq que a diretora aprendeu, durante seu estágio em sua escola, o papel do corpo como articulador da presença do ator e a função da máscara como mediadora dessa potência criativa. Esses ensinamentos ajudaram Mnouschkine a se afastar de uma metodologia psicológica de atuação ${ }^{11}$, estabelecendo uma busca pela forma na materialidade física do corpo do atuante, alicerçada nessa transcendência preconizada por Lecoq no rejeu, como ponto de inflexão para que as máscaras trabalhadas pelos atores expressem uma verdade que emane do ator e corroborem, juntamente a um retorno ao estilo dramatúrgico clássico e a influência estética do orientereferencial, nos instrumentais poéticos organizados em muitas das encenações do Soleil.

Podemos perceber essas ferramentas no ciclo de três peças intitulado Les Shakespeare: Richard II (1981), La nuit des roi (1982) e Henry IV (1984), nas quais Mnouschkine retoma a dramaturgia shakespeariana com influências

${ }^{11}$ Consta que o primeiro trabalho do grupo "Gengis Khan", tenha sido dirigido com o livro de Stanislavski como princípio norteador para Ariane. 
físicas colhidas do Kabuki, do Nô e do Buranku, atreladas ao teatro ritual, que essas linguagens escolhidas para a representação requerem. ${ }^{12}$ Essas montagens convidavam os atores a trabalharem "como se fossem" orientais, recobrindo a cena com uma camada imaginativa correspondente a esses teatros orientais, tais como uma máscara, que recobrisse finamente os textos de Shakespeare e os transportasse para um distanciamento das referências da época elisabetana, ao mesmo tempo em que obrigava os atores a criarem, por meio de seus corpos, os signos físicos que remetiam a uma trupe japonesa colocados no jogo da cena, recriando o oriente requisitado através da imaginação e da ludicidade, mais do que através de uma intensa pesquisa acerca da linguagem dos teatros orientais. Essa camada de significação alicerçada no jogo já demonstra um entendimento de mascaramento da cena organizado pela estética adotada no interculturalismo do grupo, e conectada com as improvisações físicas dos atores, para conferir uma forma, que corresponda a visão poética da diretora sobre determinada peça. São essas camadas sobrepostas que configuram uma referencialidade significativa, que faz emergir certos símbolos em detrimento de signos na cena, no caso de Les Shakespeare, a criação imaginária dessa trupe de teatro oriental, exigiu que se pudesse referenciar fisicamente símbolos orientais de movimentação, gestos e atitudes para que a significância estética da montagem pensada por Mnouschkine se tornasse presente, mas ao contrário de uma criação pautada em uma pesquisa histórica nos moldes de Stanislavski ou mesmo em um intenso treinamento da linguagem do teatro oriental, como seria provável nos estudos de teatro antropológicos que emergiam na época, o que vemos é a mixagem de uma multiplicidade de referências na presentificação do corpo em jogo (o que poderia, em muitos trabalhos, criar um impedimento criativo para o ator), que é possibilitado com a medialidade da máscara em rejeu, logo, o ator vai respondendo em separado a cada provocação solicitada em cada camada de significação,

\footnotetext{
${ }^{12}$ Sobre essa influência ritual e sobre a sua recriação do Oriente Ariane afirma "Nada é japonês em Ricardo II: as referências ao Kabuki, ao Nô, ao Buranku se mantêm ao lado do rito, como vestígio e não como molde" (HELIOT,1982 apud QUILLET,1999:83)
} 
respondendo com sua imaginação e inspiração, até criar uma visão da cena, deixando que as mixagens apareçam como uma preocupação da encenação, e não exatamente de sua atividade atoral.

Se durante todo o processo de treinamento e preparação de cenas os atores do Soleil são conduzidos pela didática da máscara, no momento em que se dedicam à criação de um espetáculo a improvisação é o disparador que conduz à rede interconectada de outros dispositivos, que formam as camadas de significação, que alimentam continuamente o jogo no grupo. Esse disparador tem como objetivo a criação de formas legíveis, conferidas pelos atuantes em consonância com o entendimento da proposta teatral sugerida pela diretora e de outros dispositivos cênicos criados pelos diversos artistas colaboradores do Soleil: texto, música, figurinos, maquiagem etc. Isso é: cada aparato cênico é materializado por esses colaboradores para que se articularem em subjetividades dificilmente representáveis isoladamente, cuja função é dar materialidade a imaginação, fazendo ver e falar pelo corpo as visões criadas durante os jogos, essas corporeidades emergem nas improvisações, chamadas de conctage pelo grupo.

O conctage consiste na divisão em pequenos grupos de atores que combinam alguns elementos da história que irão representar, sem que haja um trabalho de mesa, em que estudem e decupem determinado texto, mas sim imbuídos dessas visões acerca das ações cênicas do texto. Nesse momento de conversa os atores se dão imagens, palavras-chaves, espaço da ação e o estado dos personagens para que possam improvisar como em um canovaccio, no qual o que menos importa são as falas dos personagens dramatúrgicos a serem representados, mas sim as ações relacionais, desenvolvidas pelos tipos criados em associação aos diversos dispositivos ofertados no jogo. Notamos por exemplo, a música criada por Jean Jacques Lemêtre $^{13}$, que participa dos conctage, criando uma partitura musical ligada a concretude física e imagética do atuante no momento das improvisações, que possibilita que a música jogue com a respiração, com o caminhar, com os estados emocionais e com a voz do ator, desenvolvendo, portanto, outras camadas de provocação para os jogos, que são sobrepostas ao figurino, às

13 musicista do Soleil desde Les Shakespeare (1981) 
maquiagens e para todos os outros dispositivos relacionais, que originam por consequência uma dramaturgia vinculada ao jogo da cena e paralela à dramaturgia textual, que é vista como um outro dispositivo de jogo, essas duas dramaturgias se conectam e destacam o corpo do ator, como o espaço onde acontece o liame de todos os dispositivos, respondendo e agindo a eles e com eles, fluindo em gestos e ações na duração da cena.

$\mathrm{Na}$ peça L'Historie terrible et inachevée de Norodom Sihanoukk roi $d u$ Cambodge (1986), o Soleil introduziu outra camada de jogo por meio da construção textual em dinâmica com os conctage dos atores feitos por Helene Cixous, que passou a contribuir com o grupo, criando conjuntamente às improvisações dos atores, um texto que provocava e alimentava o trabalho coletivo, o dispositivo do texto feito ao longo da montagem denota, nessa montagem, uma preocupação de Ariane de desenvolver uma dramaturgia ainda mais pautada no trabalho do ator, e por mais que tenha voltado repetidas vezes para os textos clássicos, a colaboração de Cixous perdurou durante muitas encenações do grupo. A autora afirmou sobre o processo de criação de Norodom:

\footnotetext{
"Entram os atores. Passando pela imensa peneira viva da atuação e da direção, a peça se aperfeiçoa e se apura. Cenas evaporam. Outras ficam. Uma cena que a autora gostava muito entra de manhã e sai na mesma noite, ela havia se enganado de peça, de estilo. Desculpe. Uma cena tímida se apresenta. É justamente ela que nós esperávamos! Por um olhar lançado bem longe um ator engrandece de repente a peça: a autora vê as cores, um rio ali onde se eleva uma parede! Imediatamente o rio passa a fazer parte do texto (...) três atores se posicionam e a autora vê todo um povo. Seriam as massas de Khmers Vermelhos? Algo para se guardar! Resta o indivíduo, cada um imenso como dez mil. Eu descubro que é pelo singular que se manifesta o universal" (CIXOUS,1985, in http://www.theatre-dusoleil.fr/thsol/nos-spectacles-et-nos-films/nos-spectacles/lhistoire-terriblemais-inachevee/une-etincelle-inextinguible?lang=fr)
}

Nessa peça, as máscaras do teatro Topeng, as marionetes e máscaras do Camboja e a dramaturgia de um oriente contemporâneo criaram associações entre um presente e um passado, alargando a tensão referencial entre o corpo e os dispositivos através da corporeidade em jogo com a criação textual da dramaturga.

Vemos assim que quanto mais dispositivos foram sendo alocados na aventura de cena pensada pela diretora, mais o corpo do atuante, com seu 
lúdico e cognição, é requisitado em resposta as camadas significativas mixadas na cena, essas respostas físicas não devem, no caso, serem apenas elementos físicos e gestuais, mas sim "recobertos por uma visão". O termo para o grupo reúne não só a imaginação, já contida nos aspectos semânticos da palavra, mas também a produção de uma forma material, que recubra a cena em cada detalhe de relação, fazendo ver rios, onde só há parede e exércitos onde só três atores marchando. Segundo Jean-François Dusigne ${ }^{14}$ : “(...) diferentemente da ilusão uma visão engaja o corpo inteiramente, o "possui", induz a sensações e estados desconhecidos e a sentimentos novos"(DUSIGNE,2013:31) associando, portanto, o corpo recoberto por essa visão, no rejogo de cena; poderíamos já supor, por essa observação da visão na fenomenologia da cena, uma espécie de mascaramento, entendido por essa ficcionalização do corpo através dessa visão, descrita quase como um arrebatamento, que recobrisse inteiramente 0 atuante, não só como invólucro, mas também em suas atitudes e imagens internas. Entretanto, o corpo mascarado no Soleil não envolve apenas o atuante e sua visão, sendo antes uma atuação quase coral, de escuta constante, contida no corpo desse individuo, uma atuação épica em domínio do sujeito. Uma entrega física e sensorial aos impulsos produzidos dentro do próprio jogo com todos os elementos contidos no espaço Da atuação, incluindo-se as visões que vêm dos outros participantes.

A mediação da máscara nesses processos, além de possibilitar as respostas de cada camada propiciada pelos dispositivos por meio do rejeu, também faz emergir uma ponte relacional entre o presente e o passado arquetípico, com os mitos e tradições clássicas do teatro e dos povos. No processo de Norodom, por exemplo, vemos que ao mesmo tempo em que a dramaturgia apontava uma contemporaneidade discutindo questões sociais e políticas do Camboja através do texto de Cixous, a construção da dramaturgia atoral indicava uma ancestralidade dos povos.

Essa ponte demonstra uma preocupação latente da diretora com a questão histórica, pois:

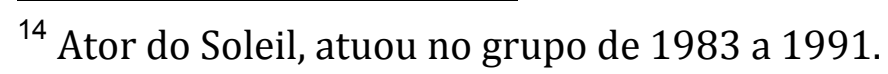


"Para Mnouschkine, história significa mais que eventos passados. Ele conota, ratifica, uma narrativa de eventos que fizeram alterar a direção das sociedades e nações contemporâneas. História, sobre essa luz, nunca está distante do presente. Passado e presente refletem dialeticamente um sobre o outro. Assim no trabalho de Mnouschkine, ela sempre conecta o que aconteceu com o que está acontecendo". (MILLER, 2007:29)

Esse atravessamento dos indivíduos pela história objetiva uma perspectiva artística que entende uma materialidade social, política e cultural inscrita nos corpos dos atuantes e que converge para uma poética de ressignificação histórica, comumente observada nas dramaturgias épicas do Soleil, desde L'Age D'Or até o atual Une Chambre en Inde(2016), pois o desejo de reatualizar os mitos e histórias dos povos e observá-los como constituinte de um presente comum, que nos abarca, independente de nós mesmo, está contido na proposta estética do grupo, e se revelam na abordagem de personagens por meio das máscaras, que é possibilitada através da emergência de certos arquétipos no rejou lecoquiano, o que traz à tona a historiografia sociocultural dos atuantes e, de certa maneira, o próprio mito contido em sua pessoa em oposição ao ser psicológico analítico da cena ${ }^{15}$. É como se a máscara dissesse: "Eu sou todos nós", e na ludicidade do jogar como criança o ator fosse dando corpo a esses arquétipos e mitos por meio de sua maneira própria de estar no mundo, de sua cultura e comunidade, questionando os mecanismos normativos responsáveis por noções estanques da história e da identidade, que estariam inscritas na corporeidade do ator, e assim torna-se possível falar do universal através do particular, o que adjetiva a questão da visão para o grupo, pois ao ser mediado pela máscara e seus arquétipos e se afastar de sua psicologia individual, o ator produziria uma imagética dos povos e de suas culturas, conduzido pelo alastramento das figuras mascaradas por seu corpo em relação a sua própria historiografia física e cultural.

\footnotetext{
${ }^{15}$ Sobre a afirmação da máscara ante ao psicologismo da cena, Ariane afirma: "Pouco a pouco, dei-me conta de que havia, apesar de todo o meu desejo, uma contradição entre a máscara e o contemporâneo. Como se o teatro verdadeiramente contemporâneo precisasse de uma interiorização mais soterrada, de uma forma mais diáfana. Por outro lado, se voltarmos a tempos muito antigos , aos mitos por exemplo, vemos que as máscaras trágicas, assim como as máscaras japonesas, mantêm toda a sua potência. (PASCAUD,2011:141)
} 
Esse atravessamento que revela os arquétipos e mitologias da cultura dos atuantes por meio do corpo mascarado, continuaram em L'Indiade (1988), que narrava o processo de independência da Índia, os confrontos entre hindus, sikhs e muçulmanos e apontava para uma "metáfora de todas as divisões e separações que nos esperam a cada dia" (PASCAUD, 2011:155). A forma dos coros gregos foi utilizada como conceito de cena, tendo Gandhi como corifeu, e a representação das tradições indianas como suporte poético e histórico, essa nova mixagem de tradições denota também a enorme possibilidade criativa que o imagético dos atuantes deveria responder nos conctages de cena, apropriando-se de uma criação de uma Índia trágica, no sentido grego, tendo a discussão sobre a polis e as relações humanas como verticalizações políticas e poéticas da experiência do ator em cena.

A tragédia grega marcou o retorno do Soleil aos textos clássicos no ciclo Les Atrides (1990-1993), porém nesse caso a mixagem se deu com as tradições indianas como Kathakali, Kutiyattan e Bharata Natyam, além de danças balinesas e danças folclóricas do Cáucaso, todas servindo de base para as criações dos coros presentes nas peças. ${ }^{16}$ Notamos que nessa peça as maquiagens-máscaras mais uma vez foram utilizadas, agora com a referência ao Khathakali, que não se utilizando de máscaras, mas sim de maquiagens-máscaras, e mantendo um corpo extremamente codificado, já apresentava a ideia de corpo-máscara há mais de quatrocentos anos, a sua complexa maquiagem ritual codificada para simbolizar a natureza dos personagens possibilita, assim como nas tradicionais máscaras de madeira ou couro, a metamorfose do ator e a aproximação imaginativa dele com o universo ficcional que irá representar. Porém, mais uma vez Ariane não faz uma peça de Khathakali, apesar de seus atores terem tido aulas dessa

\footnotetext{
${ }^{16}$ Sobre a construção desses coros, Mnouschkine afirmou : "Para encenar o coro, fazê-lo mexer, eu sabia somente o que não queria. Achava que os deuses do teatro nos mostrariam o coro um dia ou outro. Mas eles demoraram! Jean Jaques Lemêtre, nosso músico, aquele que faz tanta coisa acontecer, tantas aparições, encarnações, achava, como eu, que o coro deveria ser muito musical. Nós sabíamos que ele cantava. Mas não tínhamos uma quantidade suficiente de bons cantores. "pois eles vão dançar". Mas como(...) Foi então que Catherine Schaub e Simon Abkarian, que com Nirupama Nityanandan, eram os grandes iluminadores do espetáculo, se encarregaram da coreografia"(PASCAUD,2011:168)
} 
tradicional dança-teatro ritual (já que não há distinção para essas artes na Índia), Mnouschkine recria a forma e a ressignifica no coro grego mantendo a sacralidade do ritual, se apropriando das formas, cores, figurinos e códigos da dança, mas elaborando-os na cena como se fossem uma máscara. A codificação do corpo-máscara pode ser ainda observada na peça Le Tartuffe (1995), no qual a Commedia dell'arte e o Topeng constituíram a base de treinamento e a sugestão de codificação das cenas, mas sem adentrarem a encenação, porém os rastros deixados nas atuações nos liga diretamente a fonte matriz das tradicionais máscaras. Entendemos que as escolhas de camadas de referências e de mixagens do grupo foi se dando dependendo do processo em si, da aventura da montagem, mas que essa interconexão de camadas gerava como que novas máscaras para os atuantes, isso no sentido da resposta física às provocações ambientais da cena, e o multiculturalismo, que se remetia ao oriente-referencial, e foi pedindo novos instrumentais para que os corpos dos atuantes pudessem relacionar os dispositivos de cena. No caso de Les Atrides: as danças clássicas indianas, aprendidas durante 0 processo de ensaio da peça. Entretanto "sempre que o ator entrava em algum momento difícil de sair durante a cena, Ariane falava: "vamos parar, voltemos às máscaras" (BRODT, 2016). Essa retomada constante ao objeto denota no grupo esse fio condutor da máscara, no qual o ator pode se apoiar para retomar um princípio gerador da cena ou fazer emergir algo escondido em seu corpo. Além de ferramenta, a máscara, para a diretora, possibilita criar imagens e formas, mas pede um ator que é "(...) um mergulhador que desce ao fundo da alma, colhe as paixões, sobe com elas, arranha, escova, talha, para fazer delas sintomas físicos e metaforizar um sentimento. Só então as imagens provocam emoções" (PASCAUD, 2011:167).

Essas camadas de jogo e mixagens referenciais observadas buscam criar formas teatrais em conformidade com uma dramaturgia épica que entrecruze a história individual com os arquétipos ressignificados no presente da cena, que nos remete ao mais humano do humano, e nos conecte a todos, remetendo à alteridade em uma constância político-cultural de atuação, e nos coloca refletidos como em um espelho no teatro, em uma afirmação do homem frente ao mundo, respondendo constantemente com seu corpo ao ambiente criado pelas sociedades em expressões gestuais carregadas de 
imagens e cognições. É esse corpo recoberto dessas camadas de significação, que anima campos de forças na cena e as dinamiza em estados emocionais e relacionais, um corpo em arte, é com ele que se dá o mergulho do atuante no jogo, que o faz carregar os signos e símbolos desse outro: a máscara, em uma conjunção e diálogo constante e conjunções estéticas, em que uma potência alimenta a outra, e assim nele se coadunam em um corpomáscara, um resultante poético desse diálogo.

\subsection{O corpo-máscara no Soleil.}

Para Agambem ${ }^{17}$, ser contemporâneo é manter o olhar no seu tempo e perceber no escuro do presente essa luz dos séculos que procura nos alcançar, dessa leitura observa-se que a contemporaneidade se escreve no presente assinalando-o, antes de tudo, ao passado, e somente aquele que percebe no moderno e recente os índices e assinaturas do arcaico pode ser contemporâneo.

Essa leitura realizada por Agamben acerca das necessidades inscritas em um presente, projetada pelo passado, corresponde a observar que a inscrição de procedimentos e estéticas, e mesmo ideias do passado sobre um presente e seus geradores potenciais de comunicação, são uma maneira de relacionar e projetar, dilatar e mixar correspondências e traduções para um presente ativo, nos observando como parte de uma mesma história, que se relaciona diretamente em nossas culturas e formas de estar no mundo. É sobre essa observação de Agamben, que entendemos nos procedimentos de mascaramentos de Ariane Mnouschkine uma correspondência ao passado, mas projetada para um futuro, isso porque a diretora, afirmada sobre as influências de Copeau e Lecoq em sua observância do papel do corpo do ator na cena e influenciada pelas formas de teatro oriental e seus procedimentos, recria e mixa esses processos em dispositivos

17 O filósofo Italiano em seu livro: " O que é o Contemporâneo e outros ensaios", percebe a linha tênue que existe entre um passado arcaico e um presente. Agamben entende que somente aquele que se liga a essa linha pode ser considerado contemporâneo de seu tempo. 
aparentemente clássicos, mas que em suas reformulações ganham novos contornos e texturas que os projetam para esse presente.

Como vimos, a observação da fisicalidade vista em sua passagem por Lecoq Ihe proporcionou um entendimento sobre a materialidade gestual do ator como instrumento maior da expressão individual e não psicologizada, mas sim afirmada pelo rejogar com certas forças transcendentais que geram uma dinâmica própria no corpo em correspondência com o ambiente do jogo. (Mesmo que artificialmente criado pelas ambiências criadas para cada cena de seus espetáculos). Essa influência do mestre francês e as máscaras orientais confeccionadas por Erhard Stiefel, mestre mascareiro do Soleil, fez Ariane afirmar a máscara como disciplina de base do Soleil, o que entendemos como os procedimentos básicos pelos quais todos os atores do Soleil devem passar, quase como uma gramática estrutural, que lhes fornecessem meios de criação. Segundo a diretora:

O ator produz no ar um texto, ele escreve com seu corpo é um escritor no espaço. Nenhum conteúdo pode se exprimir sem forma. Existem muitas formas, mas para conseguir algumas delas talvez exista uma só disciplina. Eu creio que o teatro é um vai e vem entre aquilo que existe no mais profundo em nós, no mais escondido, e sua projeção, sua exteriorização máxima na direção do público. $A$ máscara requer precisamente esta interiorização e está exteriorização máxima. (MNOUSCHKINE apud ASLAN, 1989:05,06)

Ariane, por diversas vezes, fala da máscara como disparadora de formas e gestualidades que devem estar coladas a certa "verdade" que emane do corpo do atuante, por mais que entendamos que a forma objetivável contida no corpo do atuante já é em si um espaço de inscrição estética, ponto que será ampliado no segundo capítulo, observamos que a diretora se refere à concretização objetiva de uma imagética que tome e remodele o corpo do atuante, uma visão, e portanto, do entrelaçamento dessas duas máximas originariam um corpo poetizado, pulsante, em ligação profunda de afectos e perceptos, tanto em quem executa a cena quanto em quem a assiste.

Podemos entender por forma todo o modo com o qual uma coisa existe ou se manifesta, sua imagem para o mundo, imagem que pode inclusive simbolizar uma ausência, como no caso de um túmulo. A palavra forma, de origem latina, designa um pressuposto de molde, e nos faz entender uma função 
relacional, que depende de um olhar externo que a nomeie, interprete ou a qualifique entre as coisas do mundo, pois somente a partir da significação dada a uma forma é possível observá-la. Portanto, a ideia de forma está intimamente ligada à codificação que se faz a partir da leitura atribuída a ela, o que torna o agente que vê responsável diretamente pela leitura possível desses códigos. Essa leitura poderia pressupor a infinidade de materiais recolhidos durante a existência desse agente ativo, mas também poderia estar relacionada à pré-codificações de ordem sociocultural atribuídas tanto a esse agente quanto à coisa em si, dessa maneira, a leitura de determinados códigos acontece em um diálogo constante entre interpretações e questões dadas a priori pelo ambiente no qual essa forma se apresenta.

Nos seres, é através do corpo que o formato ganha expressão no mundo das coisas, ele modela e atua como um duplo no comparativo com o espaço do qual se destaca para ganhar relevo, profundidade e volume, pois indica relações espaciais ao mesmo tempo em que cria desenhos sobressaídos dessa espacialidade criando, assim, uma dimensão do físico, que é ao mesmo tempo um desenho de amplitude espacial e uma paisagem recortada de direções. Assim, corporificar ou dar forma a algo, também indica um olhar externo, que possa observar essa estrutura; para o ser, aquele que cria essas dimensões, ganhar uma forma indica uma "maneira de exprimir que meu corpo está no mundo" (MERLEAU-PONTY, 2011:147) e ao mesmo tempo, dinamizar esse mundo externo através dessas formas desenhadas no tempo-espaço. O corpo em si, segundo Merleau-Ponty, já tem essa dupla dimensão perceptiva, entre o estar no mundo e o habitar-se, entre a singularidade de espaço corporal e o espaço universal. Sempre carregado de múltiplas interpretações simbólicas, o corpo carrega essa potência dialógica de ser e estar, o primeiro enquanto significância espaço-temporal na dupla função de ser para si e para o outro, e o estar na significância temporalespacial associada à transitoriedade para ambos os agentes: eu e o outro. Esse entendimento transitório entre os agentes, também é um espaço de escritura simbólica e relacional, pois o corpo já carrega, através de sua sociedade e cultura, determinados signos e símbolos que são expressos por sua gestualidade e modo de estar e ocupar o mundo. Portanto, existe um atravessamento do corpo pelo ambiente relacional em que está inserido e, 
levando em conta que esse ambiente é permeado por uma cultura fundada por uma ancestralidade, esse corpo guarda a história de seu povo desde o jeito como vê e interpreta até a maneira como se relaciona com outros corpos, subentendo, assim, um mecanismo de legitimação política do individual na esfera pública e também dos aspectos público na corporeidade singular, compreendidos através desses acordos dialógicos.

No caso do teatro, o atuante tem como pressuposto dar corpo a uma ideia, pulsão ou desejo, esse "dar corpo" acompanha o dialogismo entre o eu e o outro, espaço de transitoriedade de signos e significantes, o corpo cria na geometrização espacial uma possível leitura de signos e significantes no próprio observador, e a máscara teatral, pode servir de ponte entre essas duas potências do espaço corporal e o espaço universal, isso porque impulsiona o atuante a desenvolver uma codificação simbólica através de seu corpo, que possivelmente confere essa qualidade de forma/imagem, isso quando o ator, responsável por animar o objeto máscara, engaja seu corpo e mente para responder adequadamente a esse trabalho, e por isso também possibilita formatos espaciais dinâmicos através de seus desenhos físicos, que simbolizam outros seres, interpretados em acordo dialógico com a plateia, que compartilha de certas significâncias criadas no fenómeno teatral. Para o ator, mascarar-se é trocar uma forma cotidiana por outra poetizada, porém levando em conta que o corpo já possui uma ancestralidade imanente em sua constituição; a máscara também pode lhe ofertar um espelhamento de sua cultura ou mesmo a possibilidade de recriar outras culturas, como no caso do Soleil, isso porque as máscaras ao mesmo tempo em que obrigam o ator a dar uma forma simbólica e codificada ao seu corpo na transitoriedade entre o ser eu e o ser outro, também o expõem, deixando aparente, durante a ação de mascarar-se, os próprios gestos e modos desse atuante, tanto em suas atitudes físicas como de cognições enraizados através de sua cultura em seu próprio corpo.

Mas, se o corpo é o suporte da forma dialógica entre o internalizado e não aparente (cultura, modos de agir e pensar e etc.) e o materializado na ação cênica do ator, então, para além dos elementos concretos (músculo, ossos, nervos e etc.) ele também é "uma espécie de âncora de experiências e composição de vivências práticas." (FERRACINI, 2013:29). Uma espécie de 
dínamo de potências e forças que, mesmo quando não ganham uma objetivação aparentemente visível, são sentidas através das formas que geram virtualidades e intensidades no atuante e no observador.

Por conseguinte, não interessa somente a própria imagem possível e geometrizada ofertada pela construção física do ator em contato com a máscara, mas sim a forma dialógica da imagem que retribui o olhar para o atuante, ao mesmo tempo em que ele executa e gera nesse jogo forças perceptíveis no observador e no observado. "O objetivo é que uma forma não seja um estilo, mas que ela seja uma força motriz" (NEUSCHAFER, 2002:143)

São essas potências e virtualidades que nos parecem o caminho possível de entendimento da "verdade" que Ariane Mnouchikine deseja que emane da forma obtida pelo ator através do contato e contágio de seu corpo, imagética e cognição com o objeto máscara, pois na ramificação das corporeidades criadas pelo ator com os códigos da máscara em afecção com os outros dispositivos cênicos criam-se espaços de potência e virtualidades próprios do jogo, que realizam essa visão empreendida na atuação, como descrito por Dusigner. Assim, nos parece interessante entender que a máscara nesse trabalho não está a priori como elemento técnico puro, mas sim está enquanto gerador de capacidades, ou ponte entre aquilo que o afeta e suas formalizações externas, trazendo assim, para o corpo (material) aquilo que não é visível, mas sim perceptível, aquilo que chamamos força, que torna o ator em um possível "atleta afetivo", como Antonin Artaud denominava.

Na verdade, a influência de Artaud sobre os pensamentos de Mnouschkine é observável desde a paixão incansável com que cria suas escrituras cênicas, como na condução dos atores em uma busca estética de formas que lhes libertem uma verdade pra além da psicologia individual. Segundo Miller, para Ariane, assim como para Artaud o "Teatro é mais vital, mais urgente que a vida cotidiana. (...) É o espaço de perigo físico e liberação" (MILLER, 2007:36). Essa libertação de potências, através do corpo, subentende uma porosidade, que regule as forças vitais contidas no corpo em contato com os afectos, que são liberadas em estados de dinâmica anímicas por meio da máscara. Segundo Mnouschkine: 
As máscaras estão aqui como uma exigência terrível e irrefutável. (...) A máscara não é uma maquiagem. Não é um objeto entre outros. Tudo está a serviço dela. Ela imediatamente os denuncia, caso a utilizem mal. São vocês que devem ceder à máscara, ela jamais cederá. Então é preciso estimá-la, amá-la(...)O ator é um receptáculo ativo, e isso não é contraditório, mas eis a dificuldade. Ele deve ser côncavo e convexo. Côncavo para receber e convexo para projetar" (FÉRAL, 2010: 61, 62)

A máscara, como libertadora do psicologismo e facilitadora do acesso aos arquétipos contidos no corpo humano, pode criar essa porosidade na escuta continua das virtualidades entre as sensações do atuante e do seu entorno (ambiência), potencializando nesse ator uma capacidade de ser afetado por qualquer dimensão, tanto interna quanto externa, o que possibilita uma dinâmica relacional circunscrita no jogo com os dispositivos acionados em uma determinada cena. Para que o diálogo se torne possível é necessário a dosagem certa de relaxamentos e tensões. A primeira, para gerar o equilíbrio psicofísico necessário para a escuta das proposições dos dispositivos na cena e a segunda para responder adequadamente a esses impulsos na estrutura poética proposta. Esse equilíbrio possibilita, para aquele que veste a máscara, a produção possível de uma imagem legível e sensível.

O filósofo Georges Didi-Huberman, em seu livro a respeito do visível nas artes plásticas, nos afirma que toda imagem manifesta uma ausência que nos olha, e nos ajuda a nos interpretar para nós mesmos, em uma dialética da presença visível e também da não manifestada nas formas, muito além da dicotomia entre o visível e o legível, que transforma o observador somente em um intérprete da forma, e não coloca em certo risco esse observador que a olha, e é por isso também olhado por ela, oferecendo-lhe uma experiência no mundo pra além das codificações tautológicas de interpretação, que dizem que "eu vejo o que vejo" e portanto apenas observo a coisa, e não o fenômeno, o acontecimento do olhar.

Huberman, refletindo sobre a dialética do visual, afirma:

"Por minimal que seja, é uma imagem dialética: portadora de uma latência e de uma energética. Sob esse aspecto, ela exige de nós que dialetizemos nossa própria postura diante dela, que dialetizemos o que vemos nela com o que pode, de repente- de um pano-, nos olhar nela. Ou seja, exige que pensemos o que agarramos dela face ao que nela nos "agarra" - face ao que nela nos deixa, em realidade, despojados." (DIDI-HUBERMAN, 2010: 95) 
Assim, atribuindo uma ação ao ato de olhar uma forma, o filósofo nos proporciona um entendimento de uma condição ativa no fenômeno de observação, possibilitando uma troca "energética" entre a coisa e o observador, um vai e vem de afectos em que ambos os participantes estão na condição de protagonistas do olhar e geradores de significâncias sensíveis, que estão mais no âmbito do fenômeno do que no do racional, e por isso extrapola os limites somente do inteligível e dimensionável na experiência pregressa do observador.

Essa proposição sobre o olhar relaciona a experiência do próprio momento presente do ser que observa como algo a ser considerado nas ponderações sobre uma forma, atribuindo uma significância ao flagrante dessa observação como gerador de presenças, e por conseguinte de ausências. Essas presenças, do ponto de vista do observador, poderiam então ser percebidas como os códigos legíveis da própria forma e da nossa capacidade de leituras acumuladas durante nossas experiências em vida, denunciando uma imersão no tempo presente e um distanciamento que torna o ver em um ato político e relacional. Contudo, a proposta de ler a ausência refletida no observável refere-se ao próprio fenômeno do olhar em arte, a aquilo que não nominamos, mas nos rapta em sensações e nos proporciona novos fluxos simbólicos, que causa um estranhamento ao mesmo tempo em que instiga uma interpretação, gerando através do reconhecido um distanciamento que quer participar ativamente do processo de construção simbólico da cena, o olhar do espectador interpreta ao mesmo tempo em que participa através da vivência na elaboração ativa da imagem feita, no caso do teatro, pelo ator. As influências desse olhar interferem nas dinâmicas das formas e geram estados de latência de escuta no atuante e no jogo relacional da cena.

Podemos atribuir o mesmo valor à máscara em seu caráter de formatador (aquele que molda) e gerador desse trânsito de fluxos de vivências, pois ao dar uma certa conformação à determinadas provocações dos dispositivos de cena (texto, direção e etc.) o atuante vê-se também tendo que zerar determinados padrões que não dialogizem a forma ao mesmo tempo em que atende aos impulsos internos, mantendo-se em um estado de atenção dilatado através do estranhamento causado na atribuição de busca desse outro ser sugestionado pela máscara. O ator, quando se utiliza da máscara, 
se desterritorializa para navegar pela aventura de achar novas personas através de seu corpo e estados emocionais, mas, para que esse reterritorializar-se em outras personas possa acontecer não basta mimetizar estados emocionais, mas sim originar através do contato com o objeto o livre trânsito dos fluxos imaginativos até uma forma precisa, que dialeticamente afeta os observadores ao mesmo tempo em que o afeta durante a prática do jogo. Não se trata, portanto, de apenas copiar determinada cultura e seus códigos (mímesis), nem de transferir determinados arquétipos para 0 ambiente simbólico do palco, mas sim de encontrar um ponto de contato entre a imagem reproduzida e a imagem produzida internamente no atuante e no observador, ligando como uma ponte esses dois núcleos ativos e geradores da tal "verdade" contida na forma fisicalizada.

Assim sendo, quando Ariane Mnsouchkine deseja que os atores apresentem uma forma física e manifesta por meio da máscara, ela também deseja uma participação ativa destes na fluição ativa do momento presente na cena, pois se pensarmos a forma criada no corpo do atuante como algo que também nos observa, seríamos então questionados por ela em uma retroalimentação, que possibilitaria um certo arrebatamento, um despojamento dos padrões aceitos naturalmente nesse jogo, uma transgressão da própria imagem. Em outras palavras, o novo. É esse não conhecimento que leva a um estranhamento, que abre lacunas interpretativas, não permitindo assim que os padrões reproduzidos por uma interpretação pautada na psicologia se apropriem do jogo dos atores, mas sim que as paixões humanas sejam recriadas por meio dos arquétipos contidos na historiografia cultural dos atores. Para Mnouschkine " O teatro não está encarregado de representar a psicologia, e sim as paixões, outra coisa completamente diferente"(FERAL,2001:80); portanto não interessa a forma pura, mas a potência dialógica da forma criada no corpo do atuante em relação à imagem reproduzida e interpretada pelos observadores na ação cênica, essa forma de força cria tensões e novas dramaturgias, e são com elas que, mesmo na ausência da máscara como objeto gerador e mediador dessa forma de potência, guarda no corpo os estados de força deixados pelas marcas do contato com o objeto, recriando os seus rastros nesse trânsito. 
Ao mesmo tempo, a metamorfose realizada no contato com as máscaras possibilita uma liberdade de criação e do eu psicológico do ator, que torna as visões (como pensada no Soleil) e os fluxos de interações realizados junto aos dispositivos em formas vivas e legíveis que podem alcançar e provocar ludicamente o público, pois distancia-se de uma lógica realista de causa e consequência da vida cotidiana e possibilita essas transgressões imagéticas calcadas no jogo. Para Phillipe Caubére, sobre o trabalho com máscaras no Soleil:

(...) a máscara era a primeira transposição do "natural" para o "teatral". Se um ator atuasse com a máscara "naturalmente", tudo o que eu via era alguém vestindo um chato e morto objeto na sua face. Por outro lado, uma vez que o mesmo ator começasse a fazer a máscara viver, a dar uma significação, um ritmo, um balanço, em habitá-la, aí uma imagem nascia, outra face era sugerida e misteriosamente um personagem aparecia." (CAUBERE, 2000, p.70)

Esse habitar a máscara, proposto por Caubére na significação conduzida pelo atuante e pela rítmica, nos parece a consequência direta da interação e presentificação da experiência relacional com os dispositivos da cena, obtida através dessa porosidade, escuta e fluidez que a máscara exige do ator no jogo do Soleil.

\subsection{O mascaramento contemporâneo e sua relação com o corpo- máscara.}

O termo mascaramento é utilizado na semiologia teatral atual para discutir as diferentes dinâmicas e procedimentos de utilização do objeto máscara nas práticas contemporâneas em que o objeto ampliou seu campo referencial. $O$ termo mascaramento pode ser utilizado como ideia e proposta tanto no âmbito do teatro, como da performance, da dança e de tantas outras artes do corpo, assim, criando uma abertura dos modelos clássicos teatrais em que novas abordagens com a máscara tornam-se possíveis. Quando falamos de mascaramento, o próprio objeto pode estar fora do âmbito de abordagem da proposta artística, como em algumas propostas do Soleil ou mesmo da Amok 
Teatro, restando em muitos casos a referência a linguagem enquanto símbolo ou no signo representado.

A máscara em si é um símbolo que contém diversos signos, mas quando há um deslocamento do eixo significativo do próprio símbolo original da máscara, mas ainda restando uma certa significância residual do objeto, observamos uma forma de mascaramento, do outro lado também podemos observar esse fenômeno, pois ao adequar intencionalmente signos distantes do universo semântico da máscara, mas que de certa forma ainda simbolize o objeto, também produzimos um mascaramento. É assim que mascaramentos espaciais, tecnológicos e virtuais tornam-se campos de abordagem da linguagem da máscara, que com essa abertura de sua liturgia primeira, agora abarca quaisquer possibilidades nas quais a referencialidade recaia sobre o ato de mascarar-se, independente do uso ou aplicação em cena do objeto máscara.

Quando dividimos a análise de referencialidade dos mascaramentos sem a utilização do objeto, observamos que a máscara resiste enquanto símbolos restantes e signos restantes, isso quando falamos sobre a premissa de observação de fora da cena, isso é, quando artistas utilizam do símbolo da máscara para outros signos que não o do objeto em si e vice versa, mas obviamente em cada caso específico de criação artística de mascaramentos, o símbolo e o signo podem estar inclusive concordando, porém defendemos, para o processo de análise, que essas criações partem de um dos pressupostos de substituição, pois caso contrário estariam coadunados e seriam a própria linguagem primeira da máscara e não um mascaramento, pois é exatamente essa ruptura entre a forma objetiva visível e a sua referência que torna possível novas perspectivas artísticas sobre o objeto.

O próprio termo ruptura já pressupõe uma realocação de coordenadas e refere-se, no âmbitos filosófico e artístico, ao pós-estruturalismo, que observa as novas maneiras de se abordar determinadas interfaces anteriormente pensadas como fixas. Essas interfaces relacionam-se diretamente às crises representacionais que tanto o homem quanto a arte passaram no início do século $X X$ e que, posteriormente, foram tomando contornos mais dilatados $e$ mixados, utilizando-se de diferentes princípios para observar diferentes 
formas, e assim ressignificando-as, dilatando as fronteiras de análise e proporcionando um ampliado campo de criação em arte.

No caso da máscara, essa ruptura se dá no princípio fundador da linguagem teatral com máscaras: a própria relação entre o objeto e o corpo daquele que a utiliza, porém, através dessa ruptura a simbolização ou a significação da máscara, se acercaram de novos dispositivos relacionais que acionam um diferencial na presentificação, mesmo que de rastros significativos, da linguagem da máscara. Esses mecanismos atuam seja através do corpo, do espaço, da tecnologia ou mesmo na completa ausência da figura do ator em cena criando uma perspectiva lacunar e outras abordagens que tencionam o entendimento sobre o objeto na cena.

Nas abordagens de mascaramentos, o que resta dessa ruptura é o símbolo da máscara e vemos que, em detrimento dos signos atribuídos a ela se apresentam outros objetos que atuam em sua significância, assim diferentes elementos substituem o objeto que inicialmente estaria sobre a face de seu utilizador, nessas abordagens os elementos que servem de máscara podem encobrir o corpo do performer, no caso de figurinos-máscara, ou o rosto mesmo, mas agora com TVs, telas de computador e mesmo celulares substituindo o elemento referencial, também em virtualidades de projeção, com máscaras deslocadas do espaço real de audiência, que são projetados virtualmente sobre corpos presentes, como formas de marcar uma presença na ausência do objeto, e também o espaço servindo de dispositivo no qual corpos de atores e ou transeuntes interajam com a metamorfose que essa espacialidade cria em determinada vivência.

Em todas essas abordagens o símbolo da máscara está relacionado com o acontecimento, mas sem que o objeto esteja presente no ato, porém tendo outros dispositivos presenciais que criem fricções com o corpo, servindo assim como máscaras, tanto para o atuante quanto para o público. Esse servir como máscara é ponto focal dessas abordagens em que utensílios, objetos tecnológicos, vestuários, maquiagens, luz, sons e toda uma gama de possibilidades se aproximam da simbolização da máscara como elemento metamorfoseante, tanto de seres quanto de espaços e tempo, levando a uma nova significação possível. 
Por outro lado, nas abordagens em que o signo referencia o objeto máscara, lemos os códigos da máscara realocados em referenciais corpóreos ou transferidos para outros objetos, em que mesmo com a ausência da máscara se cria uma sensação de que estamos lidando com a sua gramática, suas abordagens e entendimentos, mas sem que nenhum outro objeto esteja simbolizando-a ou mesmo sendo manipulado na face do atuante. Nesse caso, vemos realocações dos signos em objetos cenográficos manipuláveis em que notamos a articulação da presença dessa linguagem específica, e no caso dessa pesquisa no que chamamos de corpo-máscara, no qual os signos da máscara estão contidos no corpo do atuante, como veremos mais a frente, nessa abordagem os diversos elementos significam a máscara sem que contudo haja um símbolo identificável que represente diretamente o objeto, mas sim essa estratégia de significação cria símbolos para a máscara onde antes não os havia. Notamos que exatamente por estarem imbricados, signos e símbolos se autoalimentam, criando diferenciais de abordagens, assim, quando o elemento de composição é simbólico, ele acaba por significar a máscara, e quando é significativo, ele cria o símbolo da máscara como resultado, dessa forma, um espaço pode ser tanto um elemento simbólico quanto significativo, dependo da proposta do artista em questão, e, mesmo o corpo pode simbolizar uma máscara (caso das máscaras faciais de Grotowski) ou significar os elementos da máscara (caso dos corpos-máscara de Ariane Mnousckine).

Entendemos que essa proposta de representar um ou outro item da significação semântica da máscara envolve um dispositivo disparador que atua inicialmente em alguma das extremidades semânticas dessa significação, devendo levar até o outro extremo, por consequência. Dessa forma, é da ruptura e realocação dos signos e símbolos da máscara em dispositivos atuantes que os mascaramentos desenvolvem outras perspectivas de entendimento do objeto, e, esses diferentes dispositivos, que propõem essas rupturas das observações iniciais sobre o objeto em questão, são escolhidos dependendo da proposta poética dos encenadores e diretores, mas também são utilizados como treinamento para a criação atoral, possibilitando um entendimento das dimensões interpretativas do ator junto à máscara. Utilizados como uma rede composta por elementos heterogêneos 
(SANCHEZ, 2010:25), esses dispositivos criam abordagens que indicam essa multiplicidade, hibridização, relativização e novos contextos políticos culturais em que se determinam uma miríade de novas poéticas e propostas de atuação, tanto no âmbito da performance teatral quanto no de pesquisas que corroboram para a emergência de novas abordagens cênicas. Entretanto, exatamente por alargar os horizontes de questionamentos nos quais a máscara atua, esses dispositivos inferem propostas e estratégias de atuação diferenciais, que podem tanto acionar uma proximidade com a linguagem da máscara quanto um afastamento desses elementos, fazendo com os mecanismos de criações do ator originem diferentes interpelações para gerar outras possibilidades de abordagens de atuação que possibilitem esses novos ambientes relacionais determinados por esses dispositivos e suas consequentes rupturas.

Essas formas de ruptura mostram um espaço da presença e da ausência no campo das artes do corpo, que percebe um espaço de atuação da própria figura humana em que as novas tecnologias e aparatos interferem radicalmente nas formas de comunicação e interação social, e distinguem interfaces de atuação teatral em que, em maior ou menor grau, o corpo do atuante é ressignificado, e nas abordagens e interfaces de rupturas criadas por meio dos dispositivos de mascaramento esse corpo é representado, dilatado e ou o subtraído inteiramente, em estratégias de desconstrução ou remodelagem da presença atoral.

A própria noção epistemológica de presença, que decidimos por adotar, nos diz que ela sempre se dá na pluralidade e na alteridade, ela é performada, produzida no ato e entende as dinâmicas espaciais de atuação com as "coisas do mundo", como GUMBRECHT em "Produção de Presença", que inferem interrelações nos quais os corpos atuam e inscrevem suas histórias e produzem um espaço de tensão com o sentido, introduzindo um enfrentamento com o que o sentido não consegue transmitir, sugerindo então um efeito de presença e um efeito de sentido (signo). Ambos efeitos podem estar separados ou interligados, dependendo das multiplicidades artísticas que se relacionam, porém a materialidade defendida pela perspectiva da presença indica que objetos e pessoas estão em um ambiente relacional em que não se necessita de um sentido para que determinadas performances 
realizem-se. As atuais abordagens tecnológicas nos demonstra possibilidades de ampliação da noção de presença, que mesmo que um corpo esteja virtualizado, no sentido temporal, e ou, espacial, a lacuna sugerida pela ausência física em um dos vértices espaço-temporal, amplia a sensação do outro, assim se remodelam possibilidades de abordagem das performances humanas, porém tendo sempre o corpo como índice de presença, mesmo que sentida ou intuída por uma ausência. Dessa forma, múltiplas poéticas tornam-se possíveis, como recriações espaciais: em que cenários inteiros e novas arquiteturas são virtualizados, mascarados, em telas de projeção nas quais o corpo atua, aproximações e distanciamentos espaço-temporais: podendo atores de diversos países contracenar em um campo virtualizado mesmo sem que estejam presentes fisicamente um frente ao outro, mas projetados nesse espaço em tempo presente para um determinado público, etc. Nos parece assim, que as estratégias de presentificações produzidas por objetos tecnológicos, alterando a noção do tempo ou do espaço em que atuam atores e observadores, dão ênfase a uma ou outra dessas noções, mascarando-as. Por outro lado, uma noção de ausência da corporeidade na cena almeja a transferência do imediato no corpo do atuante e mesmo a sua substituição completa por interfaces que criem outros modus operandi de inscrição espaço-temporal, como nas possibilidades holográficas, que mesmo gravada em outras épocas possibilitam, num espaço presente, observar uma determinada performance, na criação de personagens por animação, que projetados sobre alguma superfícies indicam uma distinção de atuação no espaço de virtualidades, ou mesmo com a supressão integral do elemento humano deixando apenas que uma máquina, programada para tanto, atue no presente com a audiência, como no caso de STIFTERS DINGE, de Heiner Goebbels, instalação performativa estreada no Théâtre Vidy-Lausanne em 2007, que trazia a ausência de atores, performers ou músicos e apresentava somente um mecanismo que produzia uma ênfase material do dispositivo maquinal, sem enredo ou mesmo pequenas ficções. Notamos assim que, de certa maneira, a ausência do ator indica uma presença de outra estrutura de cena, e que a combinação de ambas (ausência e presença), nas criações em que se atuam atores e público, desenvolvem formas relacionais distintas de interferência 
tanto nas ambiências cênicas quanto nas multiplicidades de atuação do corpo nesses ambientes, indicando os mascaramentos tanto dos espaços quanto do corpo como possíveis novas dramaturgias construídas na interação entre homem e tecnologia, no qual os recursos tecnológicos estão diretamente relacionados a problematizar em si a cena.

Essas interrelações criam espaços de tensão que ampliam a questão dramatúrgica, e quanto mais os diferentes elementos vão sendo tensionados com a presença e ausência do atuante, mais o teatro se afasta de uma psicologia interiorizada, para oferecer um gesto, que responda às provocações criadas por essas tensões, e que rompa o espaço e tempo relacional da audiência, recriando-o em espaços de subjetivação em que se pode aferir um mascaramento espacial e ou temporal, como uma porta entre aberta, em que se pode ver em duas dimensões: dentro e fora, um contato e uma distância, uma presentificação e uma ausência.

Por outro lado, mesmo com a absoluta retirada da tecnologia do âmbito da cena, também podemos notar os mascaramentos através da reminiscências dos deslocamento e supressão entre signo e símbolo nas interfaces da cena contemporânea, que acabam indicando uma presença ou do ator ou da máscara e suas intersecções, como no caso dos mascaramentos corporais de Ariane Mnouschkinne, indicada na presença amplificada do atuante em uma cena marcada pela significação da máscara em seus corpos, virtualizando a máscara na ausência dela em determinados espetáculos, mas potencializando por meio dessa ausência a presença física poetizada dos seus atores.

Assim, observamos que o mascaramento é um jogo de esconde-esconde, no qual se transfere um referente e um referencial entre esses signos e símbolos, com vista a problematizar o ambiente relacional entre ator $\mathrm{e}$ público, seja com deslocamentos espaciais ou temporais proporcionados pelas tecnologias ou mesmo pelo corpo do ator.

Quando então indicamos um corpo-máscara, como uma forma de mascaramento contemporâneo estamos observando o deslocamento do símbolo da máscara, do próprio objeto, e a consequente criação de uma virtualidade desse objeto na sua ausência em cena, mas na sua presença nos corpos, que são assim grafados com a linguagem máscara. O próprio 
corpo como instrumento fundamental de expressão do sujeito é também um objeto com uma conformação no mundo, portanto pode ser lido como aquilo que se dá a ver outrem, e pode ser visto como espaço de confrontação entre humanidade e animalidade, dentro e fora, expressão e introjeção e a máscara em contato com o corpo age diretamente sobre o sistema nervoso, através de sua ruptura da organização habitual do corpo, que nessa dinâmica, cria intensidades latentes, um vir a ser da máscara sobre o corpo. Adentrando esse contexto com vista ao alinhamento da máscara, enquanto proposta de linguagem atoral temos uma multiplicidade de hibridização em performers, encenadores e artistas diversos que se utilizam de várias formas de mascaramento enquanto objeto ou significação no chamado campo expandido da cena contemporânea, assim, nesse sentido ampliado, podemos conceituar a máscara como qualquer interferência que se faça na fisicalidade do atuante afim de que se destaque ou contraponha os signos envolvidos em sua atuação, influindo diretamente na forma apresentada pelo corpo, reformando-o tanto para o ator quanto para o público, e assim, não necessariamente criando uma metamorfose completa, como a máscara inicialmente propõem, mas podendo apenas sugerir interferências que corroboram em alguns sentidos poéticos para a cena.

Nesse campo de investigação, quando referenciamos a máscara com vista não ao desenvolvimento de poéticas e linguagens, mas sim às investigações de procedimentos de treinamento e criação para o ator, no atrito relacional entre o objeto e o corpo do atuante, estamos observando a criação a partir de uma dramaturgia atoral nas poéticas cênicas contemporâneas. Destarte o corpo no palco é sempre um signo, sempre está mediado, e as implicações dos signos da máscara sobre esse corpo indica mediações distintas, que quando são suprimidas, de alguma maneira, designam também formas distintas de mascaramento, nos quais um ou outro referencial ainda se mostra enquanto presença e ausência nesse jogo de interfaces e elisões entre o corpo e a máscara em que se relativiza, as materialidades da comunicação.

Sobre esse aspecto a presença e a máscara relacionam-se de forma diferencial com dois diferentes dispositivos de discursos cênicos: a teatralidade e a performatividade. A teatralidade enquanto uma inerente 
qualidade humana de ficionalizar-se em frente a outra pessoa, independente da linguagem teatral é o "território da máscara" (SANCHEZ,2010:28), e portanto entende essa aproximação entre um observador e um atuante que se utiliza do objeto em sua face para criar alteridades em sua qualidade de se fazer do outro seu espaço de atuação e significação, assim a presença da máscara em fricção com o corpo do atuante dispara estados de relações e códigos na cena, porém, quando contraposto a questão da ausência da máscara na ação cênica, há uma relativização e novos contornos semânticos para a questão da presença, a máscara teatral também ressignifica sua atuação junto ao corpo do atuante (como veremos no segundo capitulo dessa dissertação). Por outro lado, "A performatividade é o (território) do mascaramento, do trânsito constante da sinceridade a máscara e da máscara a sinceridade" (SANCHEZ, 2010: 28), e portanto, a relação do atuante com o objeto desvela uma ação que atua para o performer por meio da máscara e dela para sua gestualidade expressiva. Podemos entender contudo que esses termos estão embrenhados, dialógicos em sua natureza, um subentendendo o outro, pois nesse jogo de esconder entre presença e ausência, o "vestir" uma máscara em si já é uma forma de esconder-se, promovida por uma transformação da forma física reconhecida do atuante, porém uma forma de esconder que subentende um revelar-se mais intrincado, que deixa o ator em contato com sua interioridade latente que busca uma objetividade gestual em seu corpo, e portanto, a lógica da presença e da ausência discutida já estaria sobre essa perspectiva incluída no próprio jogo de mascarar-se como o conhecemos hoje. Assim, toda presença indicaria uma ausência latente e vice-versa, deixando rastros de identificação de um princípio no outro.

Dessa maneira, no corpo-máscara podemos inferir que a ação do atuante com si próprio no ato do mascaramento é investida do trânsito dessa sinceridade, que o mascaramento pede para que possa acontecer. No trabalho, com vista ao teatral, seria como se no treinamento e no trabalho de criação de cenas os atores se imbuíssem dessa verdade por meio da máscara, em busca de em seguida teatralizarem-se para a atuação de determinada peça, quase como se utilizassem de dois procedimentos distintos: performar a máscara para se chegar a uma ação potente e depois 
teatralizá-la no fluxo de signos de uma peça, unidos no jogo cênico por meio de mixagens e respostas a diferentes dispositivos que possibilitem o trânsito da abordagem de criação de personagens da máscara para propostas de uma potência expressiva de um corpo em uma ação performativa.

Sabemos que esses índices teatralidade e performatividade estão embrenhados em práticas distintas de atuação, e portanto não são diretamente coadunados, mas nos parece que na experiência dos treinamentos e criações pautados no jogo, o atuante desse teatro mascarado deve implicar seu trabalho interior ao seu corpo, com vista a moldar os gestos e torná-los ao mesmo tempo cheios de seu imaginário e cognição, uma ação única e não repetível, e assim realiza no momento do trabalho com o objeto máscara uma performance que visa uma teatralidade, pois como afirma Copeau, o ator : “ (...)não pode doar nada que não doe a si mesmo, não em efige, mas de corpo e alma, sem intermediações. Tanto sujeito quanto objeto, causa e fim, matéria e instrumento, sua criação é ele mesmo" (COPEAU apud SAINT-DENIS, 2016:IX). Então, o ator desse mascaramento deve agir no momento do jogo com a máscara em uma presença corpórea potente, como se fosse a primeira vez, no fluxo continuo de afectos da cena, e só ai, posteriormente, com esse corpo em estado de força, realizar a personagem, em uma intersecção da potência da ação performativa e da ação cênica.

Se pensarmos que essa investida do ator para com si próprio e dele para com o objeto é um território de transitoriedade, que diga de si ao mesmo tempo em que ficcionaliza-se, então podemos sintetizar a relação da máscara com a presença do atuante na teatralidade e na performatividade sugerida por Sanchez como: 1. A máscara utilizada na teatralidade: A presença da máscara atualiza o psicológico do ator, que ao seguir as indicações sugeridas pelos traços significativos da máscara, desenvolve um desgarrar-se de si para transbordar no personagem a ser criado e nesse fluxo empenha-se inteiramente a esse dar forma ao outro, um aprendizado de ser dois e não um a atuar, ser estrangeiro de si mesmo, entendendo no seu corpo essa distância entre a máscara e o seu ser psicológico, que possibilita a ilusão de ser esse outro, mas que ao mesmo tempo exige um estado de prontidão para servir a esse ser que emerge do jogo. A máscara, nesse caso, é um dispositivo que dispara uma angústia de ter um desconhecido emergindo do 
seu envolvimento com o corpo, ao mesmo tempo em que identifica os sujeitos do jogo e possibilita que certas fricções sejam geradas entre eles, e que o ator responda a essas fricções gerando, em seu corpo, ações e gestos que compõem sua teatralidade na cena. Segundo a diretora:

\begin{abstract}
"A máscara é uma ferramenta magistral. Ela obriga imediatamente o ator a dar a verdade uma forma, a obedecer, a ceder a esse outro alguém, esse ser que ele veste no rosto e cuja alma ele acolhe. A máscara é uma bruxa que modela o corpo dos atores como se fosse argila". (PASCAUD, 2005:141).
\end{abstract}

2. Na fricção da máscara com o corpo do ator: A ausência da máscara, após certa fricção com o corpo do ator nos treinamentos, desenvolve um campo de força relacional que se torna perceptível na presença do corpo em arte do atuante, que relaciona a referencialidade do objeto à gestualidade criada no ato performativo.

3. No caso do Soleil: Os códigos da máscara servem como disparadores de formas imanentes que ecoam pelo corpo do ator, friccionando a presença e a ausência do objeto no corpo até que dele se extraia uma verdade não como ser, substância, mas sim como visão, que the rompa as fronteiras, oferecendo não só uma outra face da qual ele pode se utilizar para gerar essa metamorfose, mas sim um corpo inteiro dinamizado, que dê conta de sustentar e dar vida as possibilidades expressivas que o objeto sugere, recebendo a possibilidade de brincar de ser esse outrem, criando, por fim, um invólucro físico que mesmo com a retirada do objeto da face, deixa seus códigos marcados e transmitidos no mascaramento que chamamos de corpomáscara. Dessa forma, Mnouchkine parece utilizar a máscara como dispositivo para a criação desses mascaramentos físicos que consequentemente se reportam à mascara original, porém sem que dela se faça uso durante a execução dos jogos de cena por seus atores. Sobre esse dispositivo, no Soleil, Juliana Birchal afirma:

Mesmo sem ser um espetáculo mascarado, todo o trabalho do ator está diretamente relacionado com este tipo de teatro. As máscaras colocam em evidência o trabalho corporal do ator. Em um caminho oposto ao do teatro psicológico, o ator mascarado - justamente por ter o rosto completamente tampado - é obrigado a construir a personagem, suas características e seus estados, através do seu corpo. Muitas vezes a construção parte da definição de um eixo 
Assim, observando as abordagens mais pautadas no jogo e na presença do ator evocadas pela máscara em contato com o atuante no Soleil, conseguimos aferir que o tratamento do trabalho do ator sobre si mesmo, realizado pela condução de Ariane, já entende certa prática performativa do ator para com ele mesmo, mas sem a determinação psicologizante do teatro realista, e sim em via de uma concretização teatralizante, na atuação das peças do Soleil, e mesmo que tal prática não seja afirmada pela diretora como uma revolução em termos de treinamento e criação para o atuante, conseguimos ver ecos dos antepassados artísticos de Ariane em consonância com seu teatro feito nesse contemporâneo para os espectadores de hoje, uma arte do presente. 


\section{Relato 2.}

\section{Relato de um dos integrantes do Ovo}

Para mim, enquanto ator, acredito que uma das coisas mais difíceis dessa profissão é colocar em uma forma, em ação, aquilo que esta dentro de você. Aquela sensação da qual o ator quer falar, ou que naquele instante do jogo tem a necessidade de expressar. Para mim, essa relação com a máscara tem muito do sagrado, do respeito, mas ao mesmo tempo, da descoberta do próprio corpo, da utilização da técnica como uma potente aliada, como uma ferramenta justa, que pode nos ajudar a chegar aonde queremos. É um meio para se chegar a um fim. Ao vestir uma máscara é preciso agir. Respirar fundo e mergulhar nas sensações. Deixar que seu corpo diga aquilo que ele quer dizer. É preciso condicionar o seu corpo ao ponto de só agir e reagir aos múltiplos estímulos, pois a forma que há para se expressar com a mascara é através da sua fisicalidade, do seu corpo em jogo, dilatado, vivo. A máscara trabalha tanto com os elementos técnicos quanto com o que há dentro de você. A ideia da máscara para mim esta muito relacionada ao quintal. À brincadeira de criança. Sem questionamentos ou amarras uma das regras é: Jogar. Brincar. Sem neuras ou qualquer tipo de julgamento. Acredito que a primeira sensação que tive quando vesti a máscara pela primeira vez, foi a de me sentir livre. E ao mesmo tempo extremamente ridículo, e com a minha humanidade exposta. E aí é que entra a outra parte da máscara. É preciso ter tempo de treino, para entender como uma máscara funciona. Acredito que o primeiro item da máscara seria de fato o jogo. Depois buscar a técnica que a máscara pede, aos poucos, lapidando aquilo que já e seu e se aliando com as ferramentas que a máscara pede para se expressar: Coluna, centro de gravidade, base, energia, gestos, tempo, espaço, ritmo e afins só servem para essa justa junção entre aquilo que já é seu e daquilo que a máscara pede para ser manipulada. E acredito que muitas vezes dessa dificuldade técnica em adquirir essas ferramentas para se expressar, aconteça uma das coisas mais bonitas da arte, que é: se humanizar. Ao vestir uma máscara, tudo o que é seu esta sendo mostrado, todos os seus defeitos e qualidades e essa busca em melhorar os nossos defeitos enquanto atores e a experiência da troca com o 
outro, faz com que nos elevemos enquanto seres humanos. E acredito que essa seja uma das melhores belezas ao se trabalhar com esse instrumento, que é tão primordial e ancestral, que esteve sempre ligado ao teatro como uma ferramenta de comunicação. Como uma possibilidade de diálogo e de reflexão. A máscara é uma ferramenta de infinitas possibilidades, mesmo que exija elementos técnicos de quem a veste, ela sempre será atual, acredito que nunca será um instrumento fechado em si mesmo. É codificado, mas ao mesmo tempo é vivo. E dessa junção creio que sempre teremos o elemento do novo relacionado ao universo da máscara.

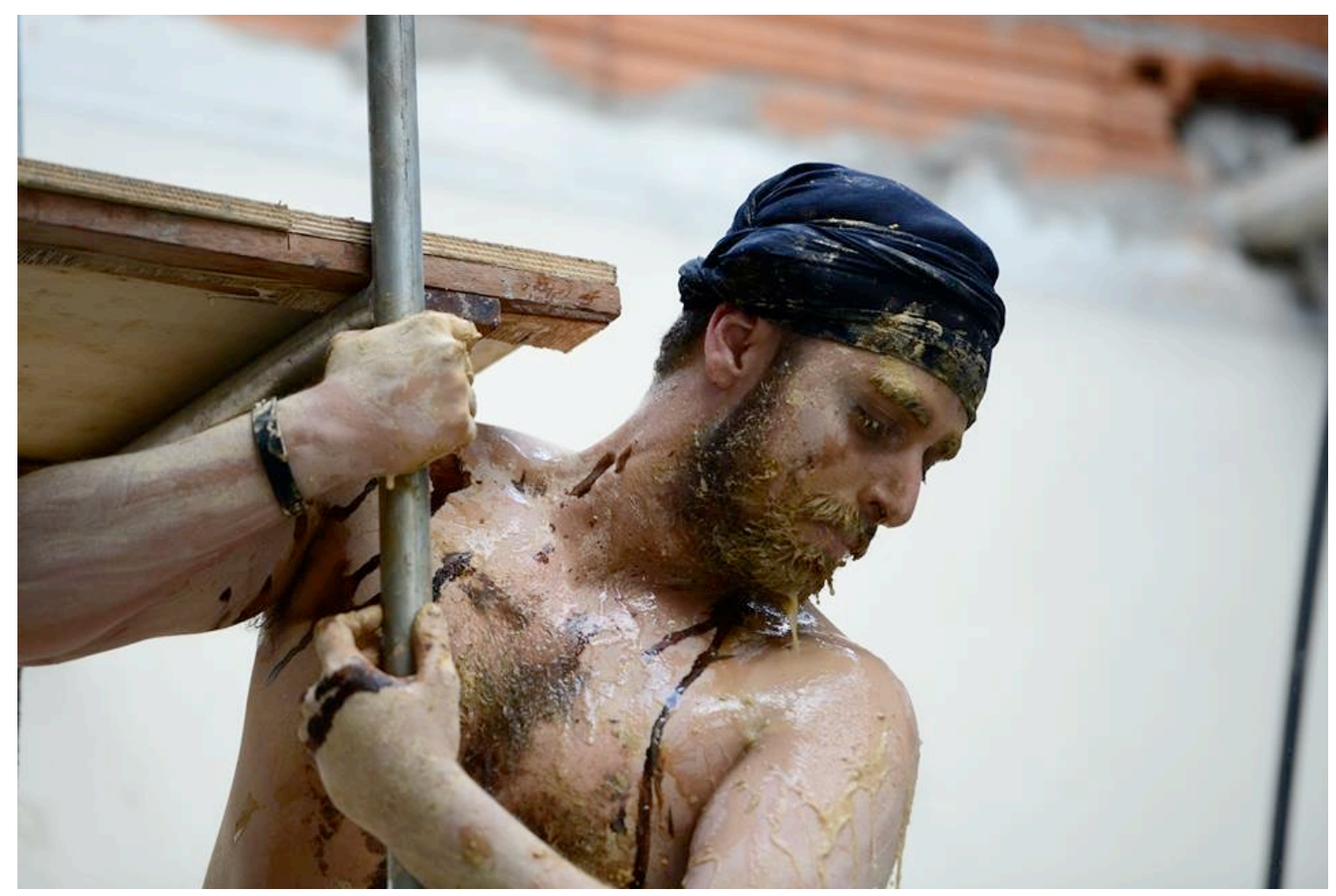

Willian Rodrigues. 
Capítulo 3. O corpo-máscara: observações práticas de trabalho.

Afim de elucidar como é possível o mascaramento corpo-máscara, em que os traços significativos da máscara são registrados na ocorrência do corpo em cena do atuante, mesmo sem a presença do objeto, mas, remetendo-se diretamente a ele como significante e significado.

Inicialmente, as proposta de readequação dos princípios da máscara para esse mascaramento envolvem um enfrentamento com certa sacralidade envolvida na relação do objeto com o teatro pois, ao se propor o exercício de cena com máscaras, as formalizações, muitas vezes parecem ser mais importantes do que a qualidade expressiva que a linguagem oferece para 0 ator, e as preocupações com os tipos consagrados como os da Commedia Dell'Arte ou as formas dos teatros orientais, como Kathakali e Nô, são indicados como registros pré-concebidos de atuação, mesmo que sem o estudo técnico para isso. Stephan Brodt (em entrevista para essa dissertação), nos fala sobre esse pensamento no Soleil:

"Ariane costumava nos falar que, pra ela, a relação com as máscaras não é procurar uma forma teatral. Ela dizia: as máscaras são uma tradição de ator (...) Muitas vezes, no trabalho com as máscaras, as pessoas ficam preocupadas com a forma, a forma é uma coisa morta" (BRODT, 2016)

Ariane acredita que as máscaras são as ferramentas de base para o ator, e que possibilitam uma entrega festiva da imaginação e do corpo, e não se furta em retirá-la da face do atuante, e mesmo do espetáculo, sem contudo deixar de referenciá-la como signo no corpo do atuante, sendo possível ver uma qualidade de máscara nos movimentos, gestos e ações dos atores do Soleil. A realização cênica fornece pistas, mas não deixa claro o caminho, pois devota do acontecimento, do jogo e do momento, a diretora não se detém em uma pesquisa prática única que pudesse nos fazer ver como se cria esse mascaramento observável em seus espetáculos. Mesmo a palavra mascaramento, muito provavelmente, já traria para Ariane certa desconfiança, pois a prática, que a diretora afirma em suas entrevistas e vídeos, entende uma dinâmica de treinamento próxima de seus mestres: 
Copeau, Lecoq e etc. Contudo, mesmo que não possamos observar uma pesquisa de linguagem única, conseguimos identificar, alguns princípios norteadores de seu trabalho com as máscaras:

1. A máscara arquetípica, como registro de uma ancestralidade do homem, e vinculava a retirar o ator de uma interpretação ensimesmada, psicologizada e que leve a uma poética realista da cena.

2. A máscara como princípio norteador de jogo, em que o corpo e a imaginação do atuante se imbriquem totalmente no momento presente da atuação, não deixando que o pensamento interfira na atuação e viceversa.

3. A máscara como princípio pivotante, no qual cada ator pode fornecer sua contribuição para a construção da gestualidade e das ações dos personagens, cada ator pode praticar quantas máscaras quiser, e o melhor de cada atuação pode ser reaproveitado pelos outros atores do jogo, em uma construção colaborativa de cada personagem.

4. A máscara como um dispositivo relacional em contato com outros dispositivos de jogo, tais como música, figurino, objetos de cena e etc. Tudo o que consegue criar um contato com o imaginário do ator em cena deve ser utilizado.

5. O princípio de atualização dos tipos da máscara e sua relação com as questões políticas envolvidas na poética de cada peça do Soleil. Esse princípio também se coaduna com a proposta de um multiculturalismo na cena, e o trabalho com as historiografias pessoais de cada ator.

6. A não sacralidade absoluta, para que se possa experimentar máscaras de diferentes origens e recriá-las sobre determinadas perspectivas. Esse princípio diferencia-se do anterior por conter um aspecto da própria poética de determinadas máscaras e não do ator propriamente dito.

7. A genuinidade para que se possa deixar ecoar uma música interna que faça com que o ator libere-se em direção à teatralidade, ao olhar alheio dos espectadores e dos outros atores. Esse aspecto também se relaciona com a generosidade na atuação, ir até as últimas consequências e se deixar levar pelo fluxo de forças contidos na cena.

Esses princípios foram utilizadas nos laboratórios, entendendo que não se realizaria uma cópia poética do Soleil, mas sim uma abordagem sobre as 
notações observadas durante a pesquisa, buscando a possibilidade de um mascaramento e não um resultado cênico assemelhado às realizações do grupo francês. A procura, em nosso caso, foi a de experienciar essas noções de atuação com a máscara de Mnouschkine, percorrendo a experiência do pesquisador em workshops com a diretora, dos registros de atividades concedidos pela diretora para diferentes entrevistadores e registrados em ampla bibliografia, das entrevistas realizadas durante a pesquisa com artistas que já integraram o Soleil e da busca pela observação prática dessa zona de transitoriedade dos signos da máscara para o corpo do atuante, o que nos possibilita não somente uma observação acerca desse mascaramento do grupo francês, mas também um entendimento geral sobre as formas contemporâneas de utilização da máscara. Assim, sabíamos que não importava o ponto de chegada ou a realização de um produto pronto, mas sim os relatos de experiências e o entendimento possível da arquitetura dos corpos-máscaras. Portanto, utilizamos essa ampla bibliografia acerca dos procedimentos e treinamentos, que nos permitiu inferir uma qualidade física de atuação na procura da prática em laboratório, praticando esses atributos até chegarmos a uma especificação que nos permitisse concluir a respeito desse corpo em cena com uma determinada qualidade expressiva da máscara.

Começamos norteando o ambiente relacional como sendo todo e qualquer espaço em que um corpo está, e que esse corpo já faz parte do espaço ao adentrá-lo e dinamizá-lo com suas ações e gestualidades, cumprindo desenhos que recortam os vértices do tempo-espaço na vivência do jogo, o que proporciona uma maior interação do atuante com a geometria espacial e as interferências relacionais, que os diversos dispositivos causariam em seu corpo.

O espaço, dessa maneira, foi pensado como uma imensa máscara, que cumpre o papel de mediação expressiva com os observadores, e contém a qualidade de reflexão espectral do espelho, em que as imagens subjetivas criadas pelo atuante e a objetivação física de seu corpo devem ser convergentes e materializadas na atuação, inferindo assim, que o que é visto é a incorporação da imagética do atuante, que responde (rejeu) às provocações que esse espaço-máscara lhe proporciona através da 
dinamização realizadas. Cada ínfimo desafio é, por esse pressuposto, gerador de uma reverberação nesse campo de relações. "O mundo não existe independente da nossa experiência" (MATURANA apud COSTA, 2014:132). O atuante, por outro lado, tendo o entendimento da materialidade do espaço, é requisitado para que aja ludicamente como uma criança, metaforizando, remodelando e recriando essa máscara-espaço através de seu corpo em dinâmicas e atravessamentos dos dispositivos relacionais, escrevendo com a pulsão da infância do corpo no espaço vazio, no qual tudo pode acontecer. Ariane, nos possibilita essa reflexão, no filme Au Soleil Même La Nuit, em que diz: "Acho que o que falta às crianças e aos jovens, hoje, são terrenos baldios. O que havia neles era justamente o aprendizado da precisão da imaginação. O vazio exterior permitia, tenho certeza disso, uma estruturação da imaginação" (Au Soleil Même La Nuit, 1997: 0:33)

Partindo desses princípios, examinamos que certas imbricações processuais dos atuantes e dificuldades de entendimento dessa relação do corpo como disruptor e dinamizador do espaço seriam bem vindas, e que quanto mais indagações e dificuldades seriam uma contribuição maior para a pesquisa, portanto não principiamos com explicações e conceitos, mas sim com uma busca por uma entrega física dos atuantes. Investimos, inicialmente, em um caminho clássico de abordagem prática da máscara para depois encontrarmos nossas próprias rupturas. Essa escolha, nos aspectos formais da pesquisa, se deu por entender que buscar criar canais de escuta, poros pelos quais se pudessem fazer fluir as sensações para o corpo e do corpo para o ambiente, como vimos no capítulo 2, seria enriquecido com a linguagem da máscara e sua gramática como um ponto de contato entre todos os atuantes, que possuíam diferentes formações, e, assim, entendiam a máscara também de forma diferente. Procuramos, assim, um fundo poético comum, uma gramática unificadora para que processássemos conjuntamente, no corpo, as diferenças e pudéssemos entendê-las com maior clareza. Dessa forma, a análise de como o espaço relacional interfere diretamente nos corpos pôde ser melhor observável nessa diferenciação, pois, compreendemos que toda ambiência também virtualiza os corpos e representa uma forma de relação cognitiva com o atuante desse espaço, como observado pelo pesquisador Mark Johnson e por Helena Katz em sua 
teoria acerca do corpo-mídia. Essa associação dos conceitos com a prática possibilita várias observações distintas por meio de cada experiência com as práticas, por essa razão a historiografia que os corpo dos atores já carregavam foi analisada na duração dos exercícios e não dispusemos de um questionário anterior a prática, não desejamos dessa maneira, uma perspectiva behaviorista de estudo, mas uma prática amparada nas sensações que o corpo gera no contato com a máscara e na fisicalização dessas sensações para os observadores.

Outra referencialidade escolhida foi a dos observadores da cena e os comentários críticos, pois entendemos que o corpo relacional é auto-poiético, e que independente de se fazer entender na relação com os dispositivos, a presença desse corpo, mediado pela máscara em um espaço vazio cria poesia, somente pelo estar e pela demanda de dinamização, independentemente de se fazer compreender, portanto não cabendo nas nossas observações questões como "não entendi" ou "não gostei". Mas seriam bem-vindas observações a respeito da leitura possível sobre o realizado e notações sobre a busca que cada atuante realizava na impermanência da cena, aceitando que "Quando um explora alguma coisa, ele aceita o risco de se perder" (FERAL, 1988:17).

Partimos, dessa maneira, da máscara neutra como primeiro procedimento, afim de criar uma limpeza gestual e equilibrar a utilização energética dos atuantes na realização de suas abordagens físicas. Para esse intento, nos acercamos de quatro máscaras de madeira confeccionadas segundo os princípios de Donato Sartori, sobre a neutra e sua leve influência da máscara Nô, escolhidas exatamente pela proximidade com as máscaras usadas por Jacques Lecoq em suas abordagens pedagógicas. Mesmo Ariane não se utilizando da neutra em seus procedimentos, observamos que era necessário alinhar uma certa proximidade com as abordagens tradicionais da máscara neutra para também escapar dos estereótipos contidos nas leituras expressivas, que viriam a seguir e assim, conseguirmos alcançar o primeiro e o quinto princípios destacados do trabalho com máscaras de Mnouschkine. Necessitamos entender um corpo disponível, prenhe de ações, que dessacralizasse posteriormente as linguagens clássicas e reinventassem suas formas de jogar com a máscara. 
Segundo Lecoq:

\begin{abstract}
"A máscara neutra é um objeto particular. É um rosto, dito neutro, em equilíbrio, que propõe a sensação física da calma. Esse objeto colocado no rosto deve servir para que se sinta o estado de neutralidade que precede a ação, um estado de receptividade ao que nos cerca, sem conflito interior. (...) Quando o aluno sentir esse estado neutro do início, seu corpo estará disponível, como uma página em branco(...). (LECOQ, 2010:69)
\end{abstract}

Era exatamente essa página em branco, esse corpo em estado de início de jogo que buscávamos através da neutra, mesmo sabendo que um estado de total neutralidade seria impossível, na perspectiva de nossa pesquisa, pois as historiografias físicas que emergem do corpo são referencialidades importantes e ponto fulcral de relação no jogo entre os atuantes. Então, os modus e formas como agem e imaginam cada um dos atuantes nos importavam, como uma coloração que os distinguisse nas páginas em branco buscadas com a neutra. Os exercícios de Lecoq foram também adaptados, para que os atuantes deixassem aparecer as múltiplas formas de se relacionar com o espaço se utilizando de suas imaginações, evitando formas predelineadas sobre uma página em branco e buscando o trânsito entre as tensões relacionais do espaço vazio, além do relaxamento interno que a máscara pedia para que ele pudesse agir e interagir com o espaço. Evitamos, dessa forma, que houvesse um jeito correto de se relacionar com a neutra e que moldes e pressupostos, mesmo que teóricos, fossem formatar os exercícios e, por consequência, os corpos dos atuantes. Qualquer pequeno gesto ou ação nos importa nessa perspectiva, mesmo sem querer comunicar nada, e nos bastaria saber provocá-lo e lê-lo, para colocá-lo em jogo com outros dispositivos.

O primeiro momento foi assim formalizado pelos princípios adaptados de Lecoq, buscando abrir a escuta para o jogo e observar uma porosidade física das afecções que possam ser originadas nesse contato da máscara e do corpo. Encontrando um ponto zero para que entrássemos na sala e respirássemos juntos para conseguir uma ambiência produtiva de trabalho: limpamos a sala coletivamente e nos preparamos assim para os primeiros exercícios. Como rotina de nosso laboratório, cada sessão de exercícios era iniciada com alongamentos baseados na Yoga, jogos de bastão e corda. Em 
sequência, preparávamos o espaço das cenas, distribuíamos as máscaras no fundo da sala e começávamos nossos exercícios com a neutra. Nesses primeiros exercícios, nenhum outro dispositivo de jogo foi acrescentado, não havia música, para não influenciar nas sensações internas dos atores, não havia um texto, nem outro jogador. Apenas um ator mediado pela máscara, em uma sala vazia, sendo provocado.

\section{Procedimentos}

Primeiro Exercício: O despertar da máscara

A máscara está tranquilamente adormecida e desperta para um novo dia, ela sente o sol batendo levemente em seu corpo, levanta-se e sente um estado de tranquilidade.

Provocação 1: O que ela vê que a deixa em estado de tranquilidade? Mostre em seu corpo o que é visto.

Provocação 2: A máscara está feliz? O que a deixa assim? Está triste? Mostre-nos.

Segundo Exercício: A máscara vai se despedir de uma pessoa muito próxima, ela nunca mais vai vê-la. Caminha até ver a pessoa, que se afasta cada momento mais até que nunca mais a veja.

Provocação 1: Onde você foi se despedir? Mostre-nos, existem pessoas em volta? Quantas?

Provocação 2: Se você está triste, fique mais triste, chegue ao desespero. Mostre-nos.

Provocação 3: Ouça sua música interna, deixe ecoar suas pulsões em seu corpo, liberte-se dos pensamentos, vivencie a música

Cada provocação era repetida diversas vezes até que algo aparecesse. 0 tempo de cada exercício foi mesurado por essas respostas, queríamos, assim, que aqueles corpos se revelassem até criar uma música interna, e que mostrassem seus estados de calma, angústia, alegria, tristeza e etc., 
explodindo, arranhando e liquefazendo os modelos pré-fixados provindos não da cultura dos indivíduos, mas da massificação cultural que se acumulava em seus cotidianos. Que os sistemas maquínicos que acorrentavam os corpos e que os deixavam passivos frente às pulsões do corpo fossem ao menos identificados, e as padronizações midiáticas nos corpus sociais daqueles atuantes reveladas. Almejamos um corpo que pensa na duração da ação, percebendo e se afetando com o outro, mas, esse corpo muitas vezes era impedido pela racionalidade extrema, que negava que o atuante pudesse conectar sensações próprias da vivência, pensando a respeito delas ao invés de agindo com elas, e assim, a máquina racional ganhava da libertação dos afetos do corpo em jogo, fazendo-os negar as contrações e tensões físicas nos exercícios. Os participantes buscavam acertar os moldes que fizessem os observadores identificarem o requerido (tristeza, alegria, tranquilidade) e assim estávamos observando os padrões aceitos socialmente desse despertar, isto é, o que cada participante havia visto, lido ou assistido como despertar ou despedir. Liamos nos corpos as referências massificadas de formatos copiados de televisões, cinema, fotos, livros e etc., como se todas as emoções estivessem contidas numa forma única de expressão. Os padrões mediatizados estabeleciam formas de comportamento, que se revelavam no vestir, falar, caminhar, consumir e principalmente, no ver e pensar dos atuantes, fazendo com que a possibilidade de alteridade fosse quase impossível e que as subjetividades já estivessem coordenadas por esses padrões que tornavam tudo mais objetificado. Essa massificação intensiva contemporânea sobre o humano, nos parece ser extrapolada pelos sistemas de globalização, que atualmente nos conecta a uma certa "sociedade da transparência", na qual uma certa positividade atravessa as formas de comunicação, rejeitando qualquer traço de negatividade que pudesse quebrar essa hegemonia, desconectando o ser de qualquer ideologia e criando, assim, uma opinião isenta sobre quase tudo, na qual o eu nega um posicionamento e uma visão de mundo, preferindo uma absorção, que transforma "as coisas (...) em mercadorias (que), devem expor-se para o ser,(e) o seu valor cultural desaparece em benefício do seu valor de exposição. " (HAN, 2014:21) 
Dessa forma, a os valores culturais são trocados por valores de mercado e os referenciais e perspectivas humanas convergem para o mesmo ponto, no qual todos veem, leem, ouvem, absorvem e pensam a mesma coisa, além de conversarem com iguais, como nos algoritmos das mídias sociais, formando grupos hegemônicos de pensamento, que referenciam as mesmas perspectivas e atividades dessa sociedade transparente. Quase como o triunfo do sistema das formas hegemônicas de padronização humana preconizadas por Foucault, em seus estudos sobre a Microfísica do Poder e sua ação sobre o corpo humano, e observamos assim que quanto mais entremeado no ser esses padrões, menos rotas de fuga são disponíveis para que se possam libertar para uma vivência na qual seja possível uma experimentação livre dessas positividades ideológicas, em que tudo deve ser visto, igualado e tornado inabitável pela assepsia histriônica, que molda a todos os corpos e comportamentos, para melhor atender aos sistemas de dominação, iniciados, segundo Foucault, no século XVIII. "Se o mundo se transforma num espaço de exposição, o habitar não é possível" (HAN, 2014:24). E, nesse mundo "Já não nos é possível ser o nosso próprio rosto. (e) A absolutização do valor de exposição manifesta-se como tirania da visibilidade" (HAN, 2014:25).

Observações do Procedimento 1: A suspensão do tempo nos exercícios fizeram com que as dificuldades encontradas nas expressões individuais ficassem mais aparentes, porém o espaço vazio, como meio de potencialização criativa, como observado por Ariane, não produzira efeito nas primeiras sessões, Mas, com a repetição, os atuantes começaram a se sentir parte integrante do espaço e, somente aí, ele pode ser uma vertente de ajuda na criação dos atores. Entendemos também que, nessa primeira sessão, as zonas de massificação culturais impediam qualquer esforço para que o lúdico aparecesse, estando os atuantes mais voltados a um propósito regimental de atender às demandas das provocações e não utilizando-as como impulsionadores de jogos. Essas expressões assépticas, praticadas nos exercícios, respondiam a essa cultura de massa ultra-expositiva, destaca por Han, e por mais que o procedimento inicial com a neutra pudesse criar uma zona intensiva de jogo e escuta da vivência, somente a continuidade prática 
poderia, ao menos, identificar para os próprio participantes suas possíveis padronizações socioculturais.

Dessa forma, optamos por seguir um outro caminho de condução daqueles atores para adentrar nas estruturas básicas do jogo, e optamos por ressaltar um princípio elementar da máscara: a ludicidade da criança, que acreditamos, criar um estado de comprometimento maior do que a busca por chegar a um ponto certo de criação atoral. Optando pela diversão para que esses corpos, no ato do jogar, se revelassem sem uma intenção estética criativa e formal que lhes impulsionava a cópias, mas adentrando o mais básico da neutra. Como diz Lecoq:

\footnotetext{
"A máscara neutra desenvolve, essencialmente, a presença do ator no espaço que o envolve. Ela o coloca em estado de descoberta, de abertura, de disponibilidade para receber, permitindo que ele olhe, ouça, sinta, toque coisas elementares no frescor de uma primeira vez" (LECOQ, 2010:71)
}

Esse estado sensorial perceptivo, citado por Lecoq, possibilita uma inocência e curiosidade, que auxilia o ator no jogo a se mostrar mais, adentrando sensações como tristeza ou alegria sem que haja um limitador racional e moralizante cristalizados pela cultura dominante. Era necessário que essa ludicidade retirasse as doxas corporais, no sentido grego de "opiniões comuns, opiniões gerais ou totalizantes. Ou, no caso mais específico, os comportamentos e clichês expressivos", pois, segundo Ferracini: "O corpo é acometido por comportamentos sociais, históricos, culturais que além de o inserirem em um código cotidiano de relações, o docilizam em sua potência de força" (FERRACINI, 2013: 76). Essas doxas prendem os atuantes em um estado de letargia que os retiram dos impulsos de vida e portanto, de criação. Seria, em nossa perspectiva, a grande barreira que a neutra deveria tentar demolir entre o fluxo da cena e o fluxo cotidiano, mesmo que soubéssemos ser apenas por um momento, no intensivo da vivência prática com o objeto, já que a recriação desse momento fugaz, recolocaria o atuante em mais um fluxo reconhecível, e imitável, de possíveis novas doxas obstruindo perceptos e impossibilitando afectos.

O procedimento seguinte constava de dois desafios: 1. Afirmar o lúdico como meio transitivo e 2. Observar se, por intermédio da neutra, as doxas físicas 
poderiam romper esse corpo dócil, permitindo perceber e se afetar com o entorno.

Durante essa fase dos laboratórios, requisitamos aos atores que encontrassem a diversão como parceira absoluta e usassem a máscara como um intermezzo, um filtro pelo qual eles deveriam empurrar as sensações obtidas durante a experiência do jogo, para que elas alcançassem o corpo, afirmando um certo traço de lealdade estética com o objeto e não uma intimidade, não deixando a máscara colar no rosto, mas sim como algo que sempre o colocasse em xeque, que sempre o desafiasse, uma esfinge a contemplá-lo, um espelho invertido de si próprio. Jogar com a neutra como estratégia de retirada das doxas também exigia que os focos dos atuantes fossem dinâmicos para que conseguissem responder às provocações que viriam de todos os lados e a todo momento, abrindo a escuta para que se pudesse criar áreas de porosidade em que os fluxos fossem recebidos e respondidos, quase que ao mesmo tempo, sem que houvesse a interferência racional, que os lançaria novamente no espaço comum. Assim, mesmo que praticassem o mesmo exercício variadas vezes, cada experiência seria única nas afecções e percepções, pois os canais sensórios de escuta absorveriam as sensações provindas do espaço relacional e os atuantes deveriam tratar de tornar essas sensações em algo carnal

Procedimento 2

Exercício 1- Escutar o silêncio I

Objetivo: Que todos batam palma juntos.

Descrição: Em um círculo, ouvir o silêncio;

1. ouvir constantemente os companheiros e deixar que seus atravessamentos também lhe afetem;

2. deixar certa tensão exercida pelo silêncio atravessar os corpos;

3. controlar a ansiedade e saber lidar com a tensão que percorre o corpo;

4. quando sentir que a tensão chegou no limite, bater palmas juntos. 
Observações: Esse exercício repetido por diversas vezes fazia com que o silêncio do próprio ambiente os tensionassem e que eles sentissem e conduzissem a tensão até uma ação: bater palma juntos.

\section{Exercício 2: Escutar o Silêncio II}

Objetivo: De olhos fechados todos fazerem a mesma ação.

Descrição: Dar a gramática: só é possível sentar ou levantar;

1. em grupo de três pessoas, pedir que fechem os olhos e mantenham fechados durante todo o exercício;

2. ouvir o silêncio e os fluxos de tensão entre os companheiros de jogo;

3. fazer uma escolha, sentar ou manter-se em pé;

4. Controlar a ansiedade

5. Deixar que a tensão percorra o corpo e o faça se movimentar e agir.

Observações: A sensação de tensionamento nesse exercício agora era recoberta pela ludicidade do exercício de tentar sentar em tempo sincronizado, e quanto mais os participantes abriam-se para as sensações provindas dos outros e da relação com o ambiente, mais eles se divertiam e possibilitavam que o jogo relacional acontecesse.

\section{Exercício 3: Falar sem usar a voz.}

Objetivo: Abrir a escuta e estabelecer um diálogo com apenas uma parte do corpo.

Descrição: Dois participantes entram no espaço;

1. selecionamos uma parte do corpo que irá falar, apenas ela deve se movimentar, todo o resto do corpo deve estar imobilizado, assim, quando as mãos falam, somente elas se movimentam e se articulam;

2. tentar estabelecer um contato verdadeiro e não dizer qualquer coisa com a parte em dinâmica;

3. evitar a verborrágia e se não entender o que foi dito, esperar o outro repetir.

Observações: Nesse exercício, o lúdico estava totalmente presente e prenhe de pulsão de vida, os participantes desejavam falar e se fazer entender. 
Situações como uma mão se apaixonar por outra, ou um pé brigando violentamente com o outro pé foram observadas. Dessa forma, o entendimento de um mascaramento começava a acontecer em nosso laboratório.

Houve uma necessidade de voltar à máscara neutra, mas agora com esse estado lúdico entendido, sabendo que seria um salto no vazio, mas que possibilitaria que os fluxos do jogo pudessem ser sentidos e apreendidos por aqueles corpos em estado de latência, que entendemos como mídia de si mesmos, que aprendiam e desaprendiam na mesma e exata proporção e que experimentavam a vivência como crianças que tateiam, experimentam e usam todos os suas sentidos em prol daquele exato momento.

As provocações nesse estágio foram elaboradas para retirar o atuante do território da racionalidade durante a atuação, assim optamos por metáforas associadas à qualidades de movimentos, em contraposição ao exercício anterior que requisitávamos emoção reconhecidas associadas ao cotidiano.

Procedimento 3: Dançar metáforas ${ }^{18}$ : Com a neutra, requisitamos que os atuantes atuassem por provocações subjetivas, para que se pudesse entender que a subjetivação das sensações complexas como alegria e sofrimento poderia se relacionar da mesma forma em suas dinâmicas com a máscara, assim requisitamos que: dançassem o amarelo, explodir brilhando, empurrar solar, tamborilar o mar, recusar prateado, correr em sangue, arrastar estrelas, sacodir tufões e etc.

Observações: Nesse jogo, o intento é fazer com que, depois de passada a experiência do mascaramento com uma parte apenas do corpo, do exercício

\footnotetext{
${ }^{18}$ Essas metáforas coadunadas com as qualidades de movimento foram pensadas a partir de trabalhos anteriormente realizados pelo pesquisador junto a investigação do Doutor Ipojucan Pereira, sobre o Mascaramento Espacial. Nesse trabalho, usávamos qualidades de movimento de Rudolf Laban e sorteávamos alguma outra qualidade metafórica que nos trouxesse esse "não saber" para que reagisse no espaço. Esse trabalho, no qual algumas vezes utilizávamos a máscara neutra, nos colocava em uma zona de criação do desbravar o espaço e do criar com ele, perdendo o protagonismo corriqueiro da ação e cedendo a esse outro espacial essa qualidade, nos deixando assim atravessar por outras máximas que não provinham exatamente do eu, mas sim na coadunação desse eu conjuntamente ao espaço.
} 
anterior, tivéssemos agora o corpo inteiro reagindo $\mathrm{e}$ cedendo às provocações, jogando como crianças e inventando com seus corpos essas outras possibilidades indicadas pelas metáforas. Conseguimos que em alguns experimentos a máscara sorrisse, e assim a dinamização ocorrida no corpo conseguiu atingir a máscara em um estado de latência e relaxamento. Essa metaforização do movimento, em nossa pesquisa, trouxe ao ator a liberdade da não referencialidade pessoal, mas ao mesmo tempo o desafio de dinamizar o imagético e o físico por meio da máscara, entrando na neutra como se "entra em um personagem, com a diferença de que aqui não há um personagem, mas um ser genérico neutro" (LECOQ, 2011:71). Sensivelmente abandonamos temporariamente à objetivação ficcional, para entrar na poetização subjetiva, para que o domínio das doxas cedesse espaço para movimentos mais prenhes de expressão em que o imaginário e a materialidade física começassem a cumprir uma aproximação, porém, observamos que, em alguns casos, os atuantes deixavam-se levar para uma subjetividade pura, não conseguindo trazer para o corpo as sensações, vivenciando um momento suspenso e introjetado, e não o presente do presente que a mediação da máscara pedia.

No terceiro procedimento, portanto, decidimos por criar um encontro entre a neutra e pequenos Hai-Kais, que poderiam criar metáforas ainda mais diversas do cotidiano, mas um pouco mais objetivadas, não ficcionais, mas com um eu poético reconhecível, que requisitasse uma expressão exterior. Também nesse procedimento, adentramos ao primeiro princípio de trabalho de Ariane pois, apesar de ainda identificarmos os espaços massificados entendidos pelas doxas, começamos a criar um território de criação de tipos, que possibilite entender traços mais arquetípicos relacionados às cenas. Sabemos que os traços dessa cultura de massa impedem que possamos ver identidades arquetípicas, pois ao unificar formas de agir e pensar no mundo, a massificação elimina os caracteres divergentes e torna exótica toda forma díspar de estar no mundo, o que faz com que haja um pré-julgamento sobre as identidades dos tipos e não nos ajuda a tentar encontrar um traço mais ancestral e coral para a máscara. Buscamos, dessa maneira, agir nas provocações de forma mais objetiva, direta e contundente possível, em busca de romper com os padrões, assim como Ariane no workshop de um mês 
frequentado por este pesquisador. Também decidimos por prolongar a duração dos experimentos para que o ator tivesse mais tempo de se perder e, quem sabe, também de se encontrar.

A primeira experimentação se deu com o Hai-Kai de Matsuo Bashô, autor japonês do século XVII, do período Edo, que é reconhecido pelos pesquisadores de literatura japonesa como aquele que estabeleceu os cânones tradicionais do Hai-kai. Sua poesia retrata a sua experiência direta com o mundo e a simplicidade das imagens, englobando o sentimento dessa vivencia dinâmica com a natureza. Escolhemos então o Hai-Kai:

No perfume das flores de ameixa

O sol de súbito surge

Caminho das montanhas

Procedimento 4: Pequena poesia Gestual.

Exercício 1:

Objetivo: Dançar o Hai-kai

Descrição: Com a máscara neutra adentrar o espaço;

1. um outro participante lê o Hai-Kai continuamente, devagar e pausadamente durante toda a duração do exercício;

2. o jogador deve se ater às palavras que lhe trazem sensações e imagens;

4. buscar não representar a palavra, mas expressar a imagem e a sensação;

5. imediatamente quando retirar a máscara, narrar as imagens.

6. outro lê em voz alta o Hai-Kai, continuamente, devagar e pausadamente como no exercício anterior

Exercício 2: Provocação de narrativas

Objetivo: Percorrer a narrativa.

Descrição : Um participante escolhe uma narrativa contada e agora, sem a máscara, reproduz a pequena história, sem usar palavras; 
Observação: A sinestesia proposta por Bashô, que envolve o olfato e a visão no movimentar-se pelo caminho da montanha, trouxe para a máscara neutra uma suavidade e um movimento conectados às sensações dos atuantes. Durante todos os exercícios, o Hai-Kai foi repetido algumas dezenas de vezes para que se pudesse criar uma musicalidade, já que optávamos pelo silêncio, contraposto à utilização de músicas que pudessem exercer qualquer influência sobre as sensações e imaginação dos atuantes, e assim conduzir para uma imagem cristalizada, que impedisse que algo ainda inominável nessa experiência aparecesse. A repetição do Hai-Kai funcionou como um disparador de jogo, que pela própria musicalidade estabelecida pelo seu encadeamento de palavra, requisitou que não nos detivéssemos sobre o significado emocional que ela evocasse no imaginário, mas sim, que ela por si conduzisse a uma sensação e imagem, que levou-os a movimentos que respondessem ao desenho fonético-sonoro, que a palavra evocava no seu inconsciente, quebrando-as, retorcendo-as, retrabalhando, sussurrando e desestruturando da palavra seu significado, para que o seus significantes pudessem atuar como disparadores de movimentos e gestualidades em respostas a essas provocações fonéticas.

O segundo exercício elaborou um primeiro ponto narrativo, no qual os atores puderam ver suas imagens retrabalhadas no espaço como um jogo no qual ainda havia a resposta ao dispositivo musical do Hai-Kai e agora, com as pequenas histórias, começavam a aparecer pontos de intersecção entre os participantes. Cada intersecção formou um grupo no qual as narrativas foram retrabalhadas para o próximo exercício.

\section{Exercício 3: Conctage}

Assim como no Théatre du Soleil, os grupos se dividiram e compartilharam imagens, sons e ideias. O objetivo dos grupos era formar um pequeno jogo, com regras, dispositivos: música, figurino e objeto (somente o texto foi objetado do exercício). Esses jogos contariam as narrativas imagéticas convergentes de uma só vez, e não necessariamente precisavam contar uma história com começo, meio e fim. Nesse exercício, também optamos por não utilizar a máscara afim de que a ludicidade permitisse um maior envolvimento 
dos atuantes e de seus desejos de criação, entendíamos que a linguagem da máscara poderia ser um empecilho inicial para suas criações, e optamos por posteriormente, quando os atuantes estivessem mais conectados com seus desejos e pulsões retornar a mediação da máscara para entender essa transitoriedade do desejo criativo individual sobre a formatação da linguagem da máscara.

O Conctage, inclui o princípio colaborativo de criação das personagensmáscaras do Soleil e induz que o coletivo pudesse começar a introduzir mais disparadores de jogo, fornecendo imagens, figurinos, objetos, música etc. $\mathrm{O}$ que faria com que os atuantes tivessem um maior comprometimento com as dinâmicas da vivência, tendo que responder a cada provocação dos dispositivos na duração da cena e posteriormente reprocessassem essa vivência a cada repetição, como vimos no capitulo 2, para que pudéssemos observar um corpo mediatizando e dialogando com cada dispositivo em cena. Observação: Os jogos apresentados, em alguns casos, geravam histórias e pareciam mais preocupados com uma forma que se fazer compreender. Em outros casos, renderam alguns movimentos corporais que não dialogavam com os dispositivos trazidos. Porém, em um caso particular, pudemos ver um jogo vivo, no qual imagens, música e objeto (no caso uma cadeira), dinamizavam o espaço e criavam momentos de suspensão de tempo. Esse jogo especificamente foi repetido quatro vezes e em cada apresentação algo novo, surpreendente acontecia, mas no infinesimal da cena, nas micropercepcões, tanto dos atuantes quanto da audiência, algo na escuta e presença daqueles atuantes começava a acontecer. Eles jogaram com os dispositivos de jogo, recebendo os impulsos que vinham de cada um dos participantes e assim "criavam um mundo" para nós. Contudo, com certa pressa de resposta, se perdiam em muitas ações que não nos deixava ver profundamente sua cena.

\section{Exercício 4: Musicando}

Nesse exercício, pedimos que todos os jogos apresentados fossem repetidos, mas agora atentando para a divisão de cada imagem e sensação, o objetivo era que os participantes conseguissem dividir cada ação, gesto e 
movimento pelo espaço, observando que de um para o outro deveria haver uma pequena pausa, um silêncio, que, acreditávamos, daria maior coerência para as narrativas apresentadas.

Observação: Os atuantes que não haviam conseguido alcançar certo nível de envolvimento nos jogos, nesta parte sentiram-se perdidos, pela dificuldade de dividir e pausar cada partícula da cena e ainda manter as imagens e as sensações, tornaram-se, assim ainda mais artificiais, sem brilho, sem teatralidade. Os que haviam conseguido alcançar o estado de envolvimento de escuta dos corpos com os dispositivos de jogo, ganharam na realização da cena uma coloração distinta, que nos fazia acompanhar cada pequeno impulso, e realizar uma leitura do trabalho. Contudo, depois de repetido quatro vezes, o exercício perdera viço, parecia que os jogadores já haviam alcançado algo com o jogo que não lhes interessava mais. Já não viviam o presente da cena, mas a ideia do que ela havia sido, precisavam da "liberdade da coisa que ainda não foi possuída" (Au Soleil Même La Nuit, 1997: 0:60).

Entendemos esse desinteresse pela cena através da perda de conexão com alguns dos dispositivos; a música que haviam escolhido parecia já não se conectar com alguns deles; o figurino de outro parecia uma roupa cotidiana e não mais algo que lhe proporcionasse um estado de jogo; parecia que "os deuses do teatro não "haviam descido" naquela noite" ( $A$ u Soleil Même La Nuit,1997: 0:70), quando o teatro não acontece, mesmo com atores, figurino, maquiagem, máscaras, músicos e etc. Seguimos Mnouschkine e retornamos às máscaras

Exercício 5: $(\mathrm{Re})$ colocando a máscara.

Nesse procedimento com os Hai-Kais, solicitamos que cada participante retornasse à máscara neutra com suas cenas e pontuações e tentassem agora jogar atentos ao dispositivo de linguagem da máscara no jogo. Retornamos também ao texto do Hai-Kai de Bashô, como música, mas agora quebrando sílabas e redesenhando sua construção silábica anterior, podendo inclusive criar um novo Hai-Kai com isso, mas que fosse utilizada a melodia criada pelo poeta japonês. Essa reestruturação silábica foi pensada para recompor os Hai-Kais em metáforas não mais precisas e reconhecíveis, mas 
sim em uma língua outra, inventada em ação pelo atuante, mas preservada em sua melodia como disparador.

Observação: As quadrinhas que apareceram, de alguma forma, lembravam os movimentos do ar, do mar e do próprio corpo humano, uma tradução que ainda sustentava o princípio do mestre Bashô, mas que agora distorcia radicalmente os significados e significantes reconhecíveis, relacionados nos exercícios com o Hai-Kai. Essa reestruturação objetivava que os significantes emergissem no corpo do atuante em forma de potência e não como uma representação desses disparadores fonéticos o que, em resposta, criaria um corpo sensível e em jogo, que aplacado de significações racionais, pudesse apenas trazer à tona as sensações inomináveis que lhes atingisse, e se utilizasse da mediação da máscara para criar certa porosidade que fizesse ouvir suas sensações dos impulsos internos do jogo, até criar uma visão, no sentido aplicado pelo Soleil, para que esses impulsos fossem transmitidas ao seu corpo e dele para suas gestualidades espaciais. Irradiando graus de potência na pulsação do jogo, que poderiam representar algumas de suas força criativas, e não um pensamento lógico-racional acerca do jogo durante a sua realização. Solicitamos, mais uma vez, que estivessem prontos a receber os impulsos internos da experiência: tudo vem do outro e da sua capacidade de, através da máscara, criar essa escuta e se deixar afetar por ela, até que ela se aloque em seu corpo, gesto e ações.

Mnouschkine, sobre a relação dessa capacidade de escuta associada a visão criada no ato pelo jogador, nos fala:

\footnotetext{
"É importante que recebam o que vem do seu interior. Porém, as visões de seu íntimo não devem impedi-los de ter as visões que vem do outro, de quem está ao seu lado. E isso talvez vocês não possuam. (...) Há também os que não ouvem as visões de seu próprio íntimo. E você não escuta bastante as visões de quem está ao seu lado no palco. Você o vê e você se diz, antes de reagir: "o que eu vou fazer com isso?" Não. Receba. O resto se faz" (AU SOLEIL MÊME LA NUIT, 1997:0:55)
}

A capacidade de escuta dos impulsos do jogo, tornam latentes para os atuantes as possibilidades de respostas ativas, e possibilitam que a máscara ganhe expressão e os corpos pareçam sustentados no espaço, organizando o tempo entre cada dinâmica física e nos possibilitando participar dos fluxos 
integrados da cena. Contudo, se qualquer dispositivo estivesse desassociado da escuta, tudo ruía em nossa frente. Percebemos que a concentração e o foco devem estar sempre muito presentes nos jogos e acrescentamos no início de nossos encontros, além das práticas de yoga, jogos de bastão e corda, também alguns exercícios de meditação ativa, conectando respiração e movimento: sentados em um espaço confortável, o atuante deve estar atento apenas à inspiração e expiração, focando apenas na abertura das narinas e no fluxo de ar, aos poucos era requisitado que se movimentassem nas expirações, com movimentos leves e na duração da coluna de ar da expiração, buscando que a duração da coluna de ar seja ampliada e por consequência os movimentos originados nela. A meditação ativa desenvolveu a capacidade de escuta dos atuantes nesse exercício com a neutra e os Hai-Kais, estávamos prontos para retirar a máscara novamente e observar os traços significativos impressos em seus corpos.

\section{Exercício 6: Mascaramento I}

Objetivo: Entender como os traços significativos da máscara podem resistir no corpo do atuante.

Descrição: 1. Cada jogador deve formalizar seus dispositivos. Quais objetos, música e etc.;

2. formalizar as ações, gestos e movimentos envolvidos no jogo anterior;

3. A máscara neutra agora não deve estar presente, porém deve-se estar atento para que o corpo possa reproduzir as visões desenvolvidas durante o jogo com ela;

4. deve-se utilizar maquiagem e figurino que representem as visões retidas na experiência anterior;

5. buscar a sinceridade com suas imagens, aceitando as pulsões criadas no jogo;

6. criar uma situação teatral em que todos os mascaramentos estejam em jogo.

Observações: Essa formalização conectiva das pulsões criadas nos exercícios com os Hai-Kais para a linguagem da máscara, desejava vincular uma liberdade criativa alcançada nos exercícios anteriores, com o ganho de 
atenção gerado pelo contato com a máscara, para agora deixar que o corpo traduzisse o estado da máscara e suas pulsões para esse corpo mascarado. Dessa maneira, não nos importamos com a qualidade artística dos trabalhos realizados, mas sim em observar se a mediação da máscara havia produzido traços significativos suficientes que pudessem ser relacionados e observados nos jogos. Portanto, não nos interessamos tanto em observar quais os dispositivos preparados pelos atuantes, pois eles serviam aqui como ponte entre a imaginação e sua corporeidade, mas sabemos que a interferência simbólica e significativa desses instrumentais estariam na concretude desse corpo em estado de máscara, pois, se o entendemos como um corpo relacional, então a ambiência desempenhada pelos dispositivos acessam diferenciais expressivos na fisicalidade do atuante.

Nos trabalhos apresentados, observamos algumas relações e aproximações entre os significantes e significados antevistos nos outros exercícios, os atores estavam mais presentes e atentos a escutar e o jogo aparentemente fluiu, por essa congruência entre escuta, porosidade e resposta. Notamos, também, que a subjetividade havia criado uma camada de significância forte, já que estávamos trabalhando com Hai-Kais e com a neutra, e a proposta de colocá-los em uma situação teatralizada atrapalhou, em alguma medida, mas fez com que fossem obrigados a fazer do imagético uma presença material de cena. Os jogos foram repetidos cinco vezes e notamos que, quanto mais praticávamos, mais as máscaras tornavam-se presentes, mesmo que ausentes enquanto objeto nas cenas, ganhando texturas e cores nos corpos dos atuantes.

Procedimento 5: Mascaramento II: Trabalhando com o texto.

Após o jogo livre do exercício anterior, escolhemos para esse procedimento trechos do texto Ricardo III, de Willian Shakespeare, pela imensa quantidade e qualidade de imagens poéticas propostas pelo autor nas tramas arranjadas do personagem-título. Os tipos, presentes na peça de Shakespeare, poderiam gerar boas máscaras para os jogos. Mais uma vez, a intenção nesse procedimento não era a de montar as cenas, nem de chegar em um resultado específico, mas sim laboratoriar os princípios do Soleil de jogos de máscara, agora acrescido de um texto para a criação dos mascaramentos. 
Nos decidimos pela cena II, Ato I, na qual Ricardo convence Lady Anne a desposá-lo. Essa cena, cheia de meandros pautados nas palavras de Shakespeare, forneciam uma multiplicidade de jogos possíveis para que Ricardo conseguisse seu intuito. Ricardo III também era um desafio que possibilitava a fricção entre máscara, o corpo e seu resultante imagético na corporeidade do atuante, aqui pensada na integridade auto-poiética do corpomídia. Para esse desafio, optamos por um trabalho com o texto inspirado nas formas de condução de Ariane Mnouschkine com Théatre du Soleil.

No workshop ministrado pela diretora, na Oficina Cultural Oswald de Andrade, pudemos observar, através do texto Tartufo de Moliére, a condução de procedimentos de abordagens do texto elaborado pela diretora. Após uma primeira leitura, a diretora dizia que não desejava que o ator se acostumasse com o texto, mas sim que o pensasse como parte integrante de seu jogo. $O$ encontro começava com um aquecimento que desejava colocar o corpo alerta para a cena, no qual os atores deveriam fazer cópias de outros atores conduzidos por uma musicalidade e em dinâmica pelo espaço.

Ariane pedia então que os atores respeitosamente sentassem e fizessem uma leitura do texto, e mantivessem seus sentidos abertos para o que quer que sentissem. Essa leitura conduzia o entendimento da situação cênica: quem, onde e porquê de cada cena que, depois em discussão mediada pela diretora, eram reabsorvidos. Essa era a única leitura baseada no entendimento da diretora durante a oficina, afirmando uma direção oposta do trabalho de mesa, que, segundo ela, engessa os atores em um entendimento racional e fechado da cena, e não os possibilita se aventurar pela imaginação e os jogos que ela lhes traria.

Nenhum ator deveria decorar o texto, a regra no caso seria estudar a cena e visualizar como os personagens jogariam em tal situação. Os textos seriam, como nos trabalhos do Soleil, lidos por um outro ator durante a realização dos jogos. Os estudos em coctage também deveriam acontecer, assim como a escolha dos dispositivos gerativos dos jogos, quaisquer elementos que pudessem apoiá-los durante a cena deveriam ser previamente estudados para essa realização.

Utilizamos, a partir desse procedimento, meia-máscaras expressivas do topeng de origem balinesa, porém não realizamos estudos sobre as técnicas 
dessa forma de teatro, queríamos que os atores criassem livremente seu próprio oriente, e sua própria forma de adentrar o mundo ofertado pela máscara, pois ela somente pelos traços simbólicos de sua arquitetura material, trataria de elucidar possibilidades de criação, ao mesmo tempo em que denuncia o que não estivesse realmente em estado de presença e criação. Sabíamos que: "Se alguma coisa não der certo, tanto faz. O objetivo é estar no momento presente, escutar, presente, escutar, ouvir, olhar, ver, sentir (...)" (Au Soleil Même La Nuit, 1995: 0:75)

Dividimos o procedimento então em :

1. Cada ator deve escolher uma máscara e um personagem que queira defender;

2. cada grupo de atores que escolheu o mesmo personagem formaria um coctage, no qual eles estudariam conjuntamente, forneceriam imagens, versos, fotos e etc.;

3. cada atuante deveria escolher seus dispositivo de cena individualmente, sem combinarem entre si;

4. ao escolher uma máscara o ator, pelo processo de completar, deve-se dar corpo para a face que encontrara, imaginar sua voz, sua atitude física e gestualidade;

5. seriam sorteados, no momento do jogo, cada Ricardo e cada Lady Anne, sem que eles tivessem anteriormente ensaiado a cena;

6. Seriam sorteados os duplos, que acompanhariam os jogadores thes dando os textos para seus personagens;

7. cada duplo deve estar imediatamente atrás da máscara que falará o texto lido por ele, acompanhando cada movimento que ela realize;

8. os duplos devem dividir o texto pela pontuação, falando cada sentença textual, e deixando que a máscara aja e repita o texto, somente depois de terminado e pontuado pelo ator o final do texto e ação, o duplo pode continuar sua leitura;

9. as máscaras devem ouvir o texto concentradamente, e somente depois, criar as ações, gestos e movimentos;

10. preferencialmente, as máscaras devem dividir as ações e movimentos de palco e o texto, mas podem colocar gestos durante a fala; 
11. há de se escutar a música interior e esquecer qualquer pensamento durante a realização do jogo.

Com esse procedimento, adentramos o universo de jogo de Ariane que, valendo-se dos princípios aventados por Artaud e também influenciada por Copeau e Lecoq, parece buscar exatamente esse ator no limite do jogo, um ator-potência que responda através de seu corpo aos impulsos internos e seja alimentado sempre pelo presente e pelo encontro, seja ele com outro ator, o texto, a diretora ou os disparadores analisados anteriormente. O texto é assim um dos dispositivos de jogo do qual o jogador se serve para impulsionar suas dinâmicas e recriar o espaço vazio da cena. Comprometido com essa dinamização, a máscara aparece na atualização do corpo em relação com as estruturas simbólicas desenvolvidas na atuação, não havendo tempo para que se realize discursos pré-concebidos, mas sim um reprocessamento constante dos impulsos criativos que emergem para o corpo com a mediação da máscara, rompendo com o tecido cotidiano do atuante em uma virtualidade metafórica, que possibilita que cognições imagéticas sejam criados na duração do seu corpo em jogo.

Observação: Praticando esses procedimentos de Mnouschkine, observamos que, quando o atuante perde o contato por uma falta de concentração ou foco com algum dos dispositivos de jogo, todo o jogo rui, como em um castelo de cartas, em que cada elemento está amplamente apoiado no elemento seguinte e que, no momento em que uma conexão é perdida, a fruição é interrompida, tendo o atuante que retomar os princípios gerativos de sua cena e mesmo eliminar certo dispositivo que não funcione, provocando-os a tirar tudo o que seja fonte de distúrbio. Notamos também, que, quando completamente apoiadas nas respostas dinâmicas do momento do jogo, as máscaras cumpriam seu papel de mediadoras e impulsionadoras de rupturas, tornavam-se máscaras-mídias, mediadora das relações exponenciais do jogo com os dispositivos e em alguns momentos elas pareciam flutuar do rosto do atuante e ganhar uma expressão viva, teatral e pulsante, que não nos deixava identificar suas próximas ações, em reatualização constante de sua imagética e cognição, pois as falas pareciam originadas de um pensamento criado durante o jogo, que não nos permitia seguir uma linearidade constante no discurso, mas nos proporcionava uma lógica criada in loco, que nos 
surpreendia, possibilitando assim, que ela cumprisse o seu elemento de metamorfose com o ator, alterando não somente o corpo, mas todo o espaço ao seu redor. A máscara, assim, tinha vida no jogo, e conseguia “(...)se apresentar como a "ruptura da rotina", um instrumento desacelerador do tempo." (COSTA, 2014:132), e que, portanto, recria as experiências vivenciadas, recriando também a espacialidade de atuação, seja ela ficcional ou não, e possibilita ao ator um rasgar das tramas do seu cotidiano a partir desse impulso, nesse caso em específico, um impulso de adaptação próprio do corpo. A desaceleração do tempo, que recria a própria vivência, levava os atuantes em um estado de jogo próximo ao da criança, que se adapta ao “jogo pelo jogo". O prazer de se estar em um presente e um descortinar da realidade apresentada pela ficcionalização. Eles trocavam, assim, sensações apropriadas de uma historicidade cultural marcada em seus corpo por uma aventura de se perder de si sem, contudo, se deixar de saber no presente. Um estado de alteridade que a própria máscara tem como fundamento e que foi possível, nesse caso, pelo rompimento do olhar sobre o próprio espaço físico da sala de ensaio através da imaginação focada em responder às provocações dos diferentes dispositivos trazidos para o jogo, e pela recriação imediata dessas sensações com a utilização da máscara, em um pacto psicofísico mediado pela máscara.

Entendemos o jogo de completar executado pelo objeto em contato com o corpo, pois se alteradas quaisquer partes do corpo, as sensações físicas remetem ao ser uma analogia de outras sensações, quase como se ele pudesse se realizar em uma outra figura, e no caso da máscara, essa alteração se dá na identidade primária com a qual nos apresentamos para o mundo: a face. É no fenómeno que se geram sensações possíveis absorvidas pelo corpo, quando em estado de latência, provocado pela não racionalidade anterior ao jogo, mas sim das cognições e imagens realizadas durante a cena com o objeto. O corpo, quando aberto à escuta dos estímulos gerados nesses exercícios, responde com uma gestualidade que reorganiza o espaço e conduz o olhar do espectador para uma ficcionalização potente, que interfere também nas sensações do observador, em um pacto de teatralidade, no qual aceitamos os códigos criados pelo corpo simbolizado na cena. Agora essas observações seriam o entendimento para o próximo jogo. 
Procedimento 6: Criando um corpo-máscara

Partindo das anotações relacionadas ao ator em cena com o objeto, buscamos recriar em cena essas sensações, agora sem a máscara, mas mantendo as codificações cedidas pelo experimento anterior. Sabíamos que não seria apenas retirar o objeto da face e executar a mesma partitura de ações praticadas anteriormente que daria ao corpo essa qualidade, mas sim a recriação até dos tipos construídos durante os jogos anteriores pois, por mais que entendamos a interferência relacional da máscara sobre o atuante, agora buscávamos um jogo sem máscara, com a mediação da linguagem, com os pressupostos entendidos ao longo de todos os outros exercícios e com o rastreamento dessa linguagem específica sobre o corpo dos atuantes.

Descrição: Na cena de Ricardo III, observar, reanalisar e preparar os dispositivos materiais de jogos;

1. buscar uma ambiência cênica que corresponda simbolicamente a visão obtida durante a realização do exercício com a máscara, e utilizá-la como mais um dispositivo;

2. procurar uma vestimenta que consiga dar corpo ao imaginário da máscara registrado na execução do procedimento anterior;

3. atentar-se para as sensações geradas na duração do jogo com a máscara, mas não a gestualidade e dinâmicas anteriores;

4. Fluir um novo momento, agora sem o objeto, não fixar o tipo, mas deixar "acontecer" um novo jogo com esses dispositivos, não preocupando-se em alcançar as imagens do jogo anterior, mas deixando que o momento gere um novo fluxo de experiência.

Introduzimos, nesse procedimento, a interferência de músicas tocadas ao vivo, que deveriam dialogar, propor ou romper com as ações dos atores. Usamos instrumentos de percussão como atabaques, bumbos e caixas para que houvesse uma proposição rítmica e não melodiosa nas ações, pois não queríamos o sugestionamento emocional que a melodia propõem ao atuante. As respostas de jogo geraram sobreposições que coloriram diferentemente 
as gestualidades de cena, mostrando que a escuta mantinha-se ativa durante a realização desse mascaramento.

Observações: Quando o atuante mantinha sua escuta aberta para as potências gerativas de dentro da cena, víamos que o corpo executava uma nova atitude física, contaminando olhos, pés, mãos e etc. Vimos outra qualidade de execução gestual e uma máscara corporal, que não desempenhava nem os traços de significação da arquitetura da máscara topeng, usada no exercício 5 , do procedimento 4 , nem as ideias e pulsões do conctage. Esses corpo em estado de máscara se realizavam no momento do jogo em nossa frente, como uma força, incorporando o ator em uma espécie de transe, que parecia ter lhe capturado em todos os sentidos. Um dos participantes, observador desse exercício específico, entendeu certa semelhança entre esse mascaramento produzido e algumas religiões afrobrasileiras e seus rituais de incorporação, o que nos parece ter sido induzido pela rítmica dos instrumentos percussivos. É preciso observar também que, em muitos outros trabalhos, a máscara de madeira, que havia sido utilizada nos jogos, parecia ainda referenciar as atividades dos corpos no espaço, mas pareciam cópias de alguma coisa que faltava na estrutura da cena, o que deixava a atuação fria e sem vida. Essa cópia era como uma saturação de símbolos, que não conseguiam fluir pelo corpo e impediam que algo realmente pulsante se mostrasse. Essa saturação simbólica pode ter sido criada pela fragilidade em algum ponto entre o relaxamento interno e a tensão mínima necessária para a ação, ou mesmo no bloqueamento de resposta a algum dos dispositivos de cena. O ator, quando saturado de símbolos, não consegue cumprir uma qualidade física que implique uma sensação de corpo vivo, e parece "correr atrás" de realizar uma presentificação, quase como um fantasma que retoma, mas não uma encarnação, como nos outros exercícios descritos. Ainda, houveram alguns exercícios em que o ator sentiu-se perdido entre tantos dispositivos e não conseguiu cumprir nem uma cópia da máscara anterior, nem a possibilidade do mascaramento. Nesses casos, a concentração para o cumprimento da atividade não consegui se estabelecer como elemento considerado no trabalho do ator, e o que víamos era uma sequenciação de dispositivos e um 
ator perdido em meio aos atravessamentos que aconteciam no espaço do jogo.

Dessa maneira, observamos que, para que o corpo possa friccionar-se com a máscara, é necessário que a concentração e porosidade do jogador estejam abertos e que o corpo consiga retornar para o espaço as sensações, em um continuum que o afirme na expressão material de suas sensações, ao mesmo tempo em que a sensação da máscara não pode ser uma regra fixada, que não dialogue com o tempo presente do jogo, para que a vivência de suas sugestões possa ser sentida, acolhida e respondida pelo atuante. Quando o diálogo torna-se pertinente, o corpo ganha uma afirmação expressiva, que assemelha-se ao jogo com a máscara e a reatualização dos tipos. Torna-se automática pela prática viva do jogo, não cristalizando uma ideia, mas possibilitando que o pensamento e a criatividade estejam a serviço das respostas ao jogo.

É necessário advertir que não estávamos interessados, nessa pesquisa, em desenvolver uma técnica, e nem mesmo uma linguagem específica, mas sim entender como seriam processados nos corpos, mediados pela máscara, essas técnicas. Se poderíamos identificar as resistências e doxas e conferir um estado máscara, virtualizado na expressividade da atuação. Notamos, também que é no trânsito entre o imagético criativo do atuante e seu corpo que a possibilidade desse mascaramento está desenhado, mas em nenhum momento decidimos por fazer o ator criar um corpo e uma máscara em separado, para depois possivelmente tentar colar o estado conferido pelo objeto. Assim, no primeiro, segundo e terceiro procedimentos, utilizamos a neutra como uma porta de entrada para a linguagem, mas não em via de ensinar didaticamente alguma técnica. O primeiro procedimento durou cerca de dois meses, com dois encontros semanais de quatro horas e possibilitou aos participantes um registro das doxas físicas e uma fricção inicial da máscara como potencializadora de suas fisicalidades. Nesse, a conjunção aventada do contato com a máscara, estudado no segundo capítulo, no qual o corpo resiste à máscara (caso A) foi observada na geração de tensionamentos corporais que, frente à mediação concebida pela máscara, possibilitou a averiguação do processamento físico de resistência à linguagem. Sabemos que a técnica da neutra busca exatamente o contrário, 
ou seja, um relaxamento físico que possibilite uma harmonia para o atuante, mas entendemos que, para que essa harmonia possa ser realizada, um equilíbrio das tensões físicas com o relaxamento devem ser acordados. Relaxamento para gerar impulsos internos e tensão para gerar movimento. Contudo, em nosso procedimento inicial, não pudemos averiguar esse objetivo nas práticas dos participantes. No segundo procedimento, com duração de um mês, já notamos uma harmonização entre a tensão e o relaxamento, possibilitada pelos exercícios de escuta e pelo treinamento de yoga. Essa porosidade física fez com que houvesse uma resposta aos dispositivos e uma presentificação do corpo no espaço, que assim passou a ser expressivo. O terceiro procedimento, mais próximo da experiência de jogo de Lecoq e com duração de um mês, trouxe melhores resultados exatamente pela subjetivação da vivência, que lhes proporcionou um estado de neutralidade e expressividade, que poderíamos atribuir à página em branco observada pelo mestre francês.

Concluímos que a resistência à mediação da máscara deve se dar em fluxos que gerem um tensionamento mínimo do corpo e é realizada com a escuta aos atravessamentos criados na vivência, quando o atuante se coloca em estado de jogo e se abre para que o acontecimento ocorra em seu corpo, e não diretamente no filtro objetivo da racionalidade, que quer nomear a prática, e não vivenciá-la.

O caso $B$, no qual o corpo possibilita um aceite das regras da máscara, pôde ser notado, nos procedimento quatro e cinco, que geraram tipificações com a máscara na execução das ações, inicialmente com ligação à metaforização subjetiva dos Hai-Kais (procedimento quatro), e depois com o disparador do texto Ricardo III (procedimento 5), como suporte de criação para os atores. O procedimento quatro, com um mês de duração, revelou um rompimento dos padrões expressivos e criações tipificadas da subjetividade. Pudemos observar camadas significativas de criações diferenciais, nas quais o corpo transformado, pelas provocações do próprio exercício, respondeu aos diversos dispositivos de jogo e criou uma ficcionalidade amparada somente nessas respostas e não na ideia fixa de uma máscara, que pudesse reagir aqueles estímulos. $\mathrm{O}$ procedimento seguinte, nos denotou inicialmente $\mathrm{O}$ contrário, e percebemos que os textos fizeram muito da inventividade criativa 
desenvolvida se perderem. Percebemos máscaras mais fixas e menos afincadas nas respostas ambientais, o que levava ao processamento dos tipos mais comumente praticados e a uma lógica racional deslocada do ato da ação. Porém, quando o texto foi realizado como um dispositivo a mais, e não como objetivo a ser alcançado, vimos a mesma pulsão expressiva do procedimento com os Hai-Kais. Compreendemos que a lógica ocidental de um teatro amparado no texto, assim como a ampliação de uma cultura massificada, inutilizaram em alguma medida o presente como meio potente para a criação, legando ao atuante a busca de um estado que seja aceito pela audiência, mas que está longe de uma criação legitima e pulsante de vida. Por fim, no caso $\mathrm{C}$, em que o corpo e a máscara amalgamam-se em estado de potência, nos mascaramentos como o corpo-máscara, foi notado, no procedimento 6 , com duração de dois meses, que esse processo talvez tenha sido o mais difícil, pois esse mascaramento somente é possível quando o corpo compreende a linguagem da máscara e sua expressão. Não conseguimos constatar um diferencial expressivo quando o atuante tentava reproduzir a tipificação dos procedimentos anteriores ou mesmo quando não havia desenvolvido uma capacidade de presença frente à resposta aos dispositivos da cena. Porém, quando a porosidade e a expressão se afetavam mutualmente, notávamos um condicionamento poético e uma dilatação do corpo no espaço, que gerava a sensação de uma máscara presente no corpo, mas ausente da cena. Portanto, entendemos que o mascaramento corpo-máscara não individualiza uma máscara impressa no corpo, mas sim realiza um rastreamento da linguagem expressiva do objeto na fisicalidade do atuante, não tratando-se assim de um refazer o jogo por meio da impressão deixada por uma experiência anterior, o que levaria o jogador a sair do tempo presente da vivência, mas sim um rastreamento da própria linguagem, uma inteligência máscara alocada no corpo do atuante, que the permite se extrair do estado cotidiano e ser lançado a um atravessamento dinâmico de sensações que geram uma gestualidade. Que nos aparenta que o objeto está de alguma maneira ainda ligado aquele corpo, criando uma lógica própria, que nos faz ver um "novo" emergir no jogo prenhe de pulsões do ator comprometido em sua atividade, rompendo sua 
expressão corpo e a tipificação comum da máscara, mixando-os em seu corpo-máscara. 


\section{CONCLUSÃO}

Para que possamos entender um corpo, que é máscara no ato da cena, é importante que observemos de que corpo e de máscara falamos, pois a multiplicidade filosófica e de poéticas práticas acerca de ambos nos possibilita uma leitura infinita de como o objeto se relaciona e cumpre um papel diferencial de agente de transformações sensíveis quando em contato com o físico do ator, possibilitando vértices infinitos de abordagens. Entretanto, o índice de pesquisa relacionado a prática com máscaras de Ariane Mnouschkine, nos trouxe uma aproximação da qualidade de atuação com a máscara que desejávamos entender.

A máscara, no Soleil guarda um mundo em si, ela aproxima o ator de seu ofício, conduz a teatralidade e promove uma "festa de atores, a festa da imaginação, da carne e da vida" (BRODT,2016), desenvolvendo uma mediação entre o corpo e o imaginário do atuante com os observadores, a máscara nessa perspectiva atua junto com o ator, mesmo quando não se encontra em cena, e gera uma porosidade e uma escuta continua dos estímulos concebidos dentro do jogo, podendo assim ser chamada de uma máscara-mídia, pensando em mídia como MacLuhan a entende, como uma mensagem em si, que já contém todo o enunciado, toda a comunicação guardada nos traços de madeira ou couro, desenhados em sua arquitetura material.

Os princípios da didática de base praticados no Soleil, subentendem uma releitura da linguagem da máscara apoiada sobre os aspectos mais historiográficos e sociais contidos nos arquétipos que as máscaras exalam, 0 que faz com que o atuante com Ariane não se perca em sua psicologia e nem leve a poética de sua cena para uma estética realista, mas sim concretize com seu corpo uma leitura política de seu mundo, distinguindo a questão da política não sobre aspectos partidários, mas sim como relações socioculturais, que dão enlevo ao habitar esse mundo com o corpo, historicizam o ser e lhe faz parte ativa de sua realidade. Quando a máscara aponta para o caminho da polis, ela também aponta para as grandes epopeias humanas, as tragédias e os textos que relacionam o ser dentro de 
uma esfera maior de pensamento, dentro de uma força motriz ética que coloca cada realidade frente a outra.

Esses caminhos éticos, também são apontado na condução colaborativa de todos os processos de trabalho do grupo francês, no qual cada artista contribui com a criação de diferentes dispositivos colocados no jogo da cena em contraste com cada ação e gesto criados pelos atuantes e mesurados pela "verdade" emanada dos seus corpos, e sentida pela audiência e por Ariane. Entendemos então, que a verdade, conceito de difícil abordagem, no caso de Mnouschkine, se relaciona com o que funciona, o que é orgânico na atuação, o que conduz uma emoção, provinda da relação daqueles corpos em contato com diferentes dispositivos, que lhes proporcionam um sair de si, e se deixar levar pela aventura da cena, um reterritorializar-se na ação, um campo de experimentação de alteridades infinitas, posto que cada participante é encorajado a praticar qualquer máscara personagem que queira. No processo do Soleil nenhum personagem é de nenhum ator, eles habitam os corpos de todos os que se arriscam a contribuir em sua formação, cada parte de cada personagem pode ter vinda de um atuante, e aquele que empunha o personagem leva consigo a história de todo o processo ao mesmo tempo, contribuindo, por fim, com a afirmação do teatro como algo comunitário e não pessoal, que Ariane imprime em seus processos.

Contudo, precisávamos entender como os corpos individuais dos atores reagem a esses diferentes dispositivos cênicos mesurados pela máscara e como essa relação pode estabelecer uma zona limítrofe entre o corpo e a máscara a ponto de que quando retiradas da face elas ainda tivessem seus códigos marcados nos corpos, no que chamamos de corpo-máscara.

Ariane não adepta de uma técnica específica para a condução dos atores, fala sobre os princípios, mas não descreve procedimentos para esses princípios, desta maneira, com o estágio realizado na cidade de São Paulo em 2010, as entrevistas concedidas pela diretora, e as entrevistas de participantes do Soleil, inferimos quais potências os corpos dos atores devem desenvolver na duração do jogo no grupo, ao mesmo tempo, em que experienciamos esses princípios em laboratório para que pudéssemos ter uma maior amplitude de abordagem não conduzida, isto é, que não fizéssemos caber na teoria o que somente a prática pode nos revelar. 
Independente da linguagem de máscara que Mnouschkine utilize, posto que para cada espetáculo específico ela se serve das confecções do mestre mascareiro Erhard Stiefel, e de diferentes formas de abordagem, alguns pontos de partida são identificáveis: 1. Ariane, não se limita a linguagem técnica, preferindo que o ator invente uma forma de empunhar a máscara, porém, depois de experimentar a linguagem da máscara em workshops ministrados por sabedores da técnica original, assim preservando algo da técnica original mas reinterpretada, reatualizadas pelos atores. 2. O que deve aparecer é o arquétipo e não uma ideia de personagem psicológico. 3. A máscara deve afetar o corpo do atuante para que ela possa criar uma conexão de jogo e não uma racionalidade a seu respeito. 4. A máscara deve se relacionar com todos os dispositivos criados pelos diferentes artistas. 5 . Deve-se ouvir a música interior para que se possa expressar, assim o corpo dança a música produzida pela afecção mediada pela máscara. 6. É importante que o corpo seja afetado por uma visão, no sentido descrito por Dusigner, de "algo que lhe tome" não só imageticamente, mas também sensorialmente, dominando inclusive o corpo.

Observamos, assim, que a exigência técnica dos atores do grupo é enorme, e todos esses pontos de partida seriam mediados pela máscara, e o resultante físico seria um corpo sustentado na espacialidade, com uma presença expressiva enorme e apoiado sempre no presente da realização do jogo. Um corpo que se alimenta constantemente das afecções e percepções produzidas dentro da cena e que as rejoga em sua gestualidade, dinamizando o espaço e tornando-o também um espaço de acontecimentos. Um corpo que produz e é produzido nos fluxos de cena, que cria cognições ao mesmo tempo em que imagens, em um processo de metaforização constante, como pensado por Mark Johnson acerca da cognição desenvolvida pelos corpos em atuação com seus ambientes relacionais, um corpo-mídia, como pensamos.

Contudo se a máscara é uma mídia e o corpo também recebe esse atributo, então, o que entendemos é uma dupla mediação fenomenológica, um corpo e uma máscara que produzem mediações de si próprios e um com o outro, gerando um dínamo de potência que atravessa os vértices tempo-espaciais e podem proporcionar a criação de um campo de força no espaço de atuação. 
Essa dupla mediação nos infere também uma transformação constante da máscara, que altera não os seus traços materiais, mas sim a sua percepção nos observadores, o que faz com que um objeto de madeira chore, sorria etc. Da mesma maneira que o corpo, nesse processo, passa por uma transformação constante de seus estados sensório-motores, e, também de sua acepção externa, gerando a metamorfose física. O corpo da máscara e a máscara do corpo são por esse entendimento colados na experiência do jogo, um subentendendo o outro na atualização constante dos fluxos dinâmicos exercidos pelos dispositivos ou provocadores de jogos, que ocasionam por essa interferência uma reatualização constante das interfaces midiáticas de ambos, o que provoca, sobre nossa perspectiva, uma realocação dos signos de um no outro, gerando assim um corpo-máscara ou uma máscara-corpo.

Esse processo se faz residualmente na constância de trabalhos e procedimentos de jogo, que provocam uma memória muscular no atuante, assim como as formações de redes neurais no processamento de cognições através dos movimentos do corpo, aferidas por Mark Johnson em sua pesquisa e reportada por Chistine Greiner e Helena Katz, realocando-se significativamente e se alojando nas expressões, gestos e movimentos dos atuantes, que produzem um estado de máscara, mesmo sem o objeto na cena, criando uma ausência que indica uma presença, como observamos nas definições de Gumbrecht.

A presença do corpo nessa cena, impregnada pela simbologia da máscara, interfere no espaço relacional em que o significante corpo passa a significar um corpo em estado expressivo de máscara na cena e recebe os signos do objeto em face da sua ausência, determinando uma diferenciação no próprio signo normativo desse corpo. Essa ausência, espaço da performance observada em Gumbrecht, no caso do Soleil, produz uma forma de teatralidade na qual a ficcionalização é partilhada pelo público enquanto o atuante está em um jogo constante com os dispositivos gerativos deixandoIhe mais afirmado no processo de dinamização espacial de sua atuação. Seria como se, ao produzir um espetáculo com a particularidade do coletivo, como Mnouschkine faz, o grupo afirmasse a performance individual do ator frente aos desafios dos jogos como forma de refletir essa polis, exigindo do 
atuante uma concentração e foco afinados para realizar seu trabalho, ao mesmo tempo, em que emana as potências expressivas produzidas na experiência para o público. Enfim, focando no indivíduo e suas idiossincrasias socioculturais atravessadas pelos elementos arquetípicos da máscara para acertar o coletivo, que por meio dos signos próprios da linguagem e pela afinação com os dispositivos podem produzir um corpo subjétil, que alcança esse estado de força pela percepção relacional dos estímulos do jogo e produz uma camada de afecção nessa capacidade de escuta, que flui para sua gestualidade, tomando o corpo como uma "encarnação" , realizando um corpo em si ficcionalizado, prenhe de símbolos e potências, que perfaz uma historicização sociocultural, nas respostas do indivíduo nas cenas, e nos conta uma história, mesmo sem nos falar uma palavra. Seria então esse o resultante do corpo-máscara, um corpo ficcionalizado, potente de jogo e ligado a seus reprocessamentos constantes da experiência de mediação do corpo-mídia no jogo.

Percebemos que a teoria relacionada a esse mascaramento considera a prática como possível desenvolvedora dessa potência corpo-máscara e sabíamos que, mesmo no Soleil, em alguns casos, o resultante em processo de treinamento não condizia com os espetáculos e que nem todos eram marcados por essa forma de atuação. Mas sabíamos que a experiência prática poderia elucidar questões relativas a esse fenómeno. Portanto, criamos alguns procedimentos na prática do jogo como um segundo passo da pesquisa, para que observássemos como se dá essa "contaminação" da máscara para o corpo. Os exercícios de cena nos possibilitaram uma análise de procedimento que entendemos em "equilíbrio precário", isto é, quando realmente alicerçado nas respostas em rejeu, com o ambiente relacional criado e mediado com a máscara, os atuantes conseguiam jogar potencialmente, criar um mundo em nossa frente e ver uma flutuação do objeto em resposta aos dispositivos. Assim, parecia que a máscara ganhava vida, saia da fixidez do rosto do ator e passava a dançar seus signos no jogo. Contudo, quando algum elemento se perdia na condução das reações, o objeto voltava a sua gestalt fixa, a uma face de madeira com uma expressão única determinada em sua arquitetura material. 
Essa prática também nos possibilitou entender que os corpos devem ter uma estado de atenção intensivo e devem dialogar com o não saber, para que, durante a atuação, se processem cognições e imagens transmitidas pela fisicalização das sensações dos atuantes, dosando assim certas tensões necessárias para que se possa responder através desse corpo, com um relaxamento interno, para que se desenvolvam essas imagens e pensamentos absorvidos pela gestualidade do atuante. Quando uma das partes elevava-se ante à outra, a fragilidade da atuação ficava aparente e a "verdade" comentada por Ariane não aparecia. Porém, para que esses corpos pudessem ganhar esse estado de atenção e relaxamento, ao mesmo tempo, era importante, em nosso laboratório, que houvesse uma preparação que entendesse uma transgressão da fixidez de escuta, que promovia uma quebra na mediação dos fluxos de cena pelo corpo. A qualidade do momento anterior ao jogo se demonstrava na capacidade de escuta e resposta dos atuantes e na escuta das sugestões da máscara para o acontecimento.

Assim, entendemos que a promoção de uma porosidade física se relaciona diretamente com a percepção da máscara como elemento não fixado, mas sim sugestivo, midiático e relacional. Quando os elementos da linguagem da máscara foram tratados como uma tipificação tradicional, observamos uma não relação significativa do atuante com seu jogo e cada dispositivo gerativo era somente um obstáculo impeditivo de sua expressão.

Porém, quando o a objeto foi utilizado como mediador da potência de escuta corporal, a manifestação sugestiva de seus signos foram processadas e desenvolvidas como expressividade na cena, e quando essa mesma atitude se revelava, mesmo sem a atuação direta do objeto na cena, também conseguíamos ver uma fluidez dos códigos da máscara em manifestação no corpo do atuante; assim não víamos a máscara, nem o corpo, mas um resultante exponencial de jogo, um acordo entre ambos, um corpo-máscara.

Concluímos que o corpo é em si um dínamo poético que carrega uma historicidade do atuante, que reflete uma história sociocultural dos povos e como máquina auto-poiética que é, tem a capacidade de processar e mediar os acontecimentos em seu entorno agenciando-os em cognições. A máscara, tanto como objeto quanto como linguagem, também possui essa capacidade de agenciamento e carrega em si uma comunicação que, quando acessada 
na relação com esse corpo, possibilita uma ruptura e uma dinâmica que transforma o acontecimento em processamento duplo entre ambas as potências, uma atualização constante que transporta os signos do corpo na máscara e vice-versa. Esse recurso expresso, no corpo, oferece uma predisposição máscara, que retira o atuante de uma ideia psicológica e o faz ganhar uma capacidade teatral, vivendo no presente do presente em um ato de comunhão consigo, com a linguagem e com os observadores, possibilitando no atuante uma alteridade que reflete a si e ao outro, intermediado pela máscara, ganhando uma pele que é história, imagética, cognição e força, sendo ele mesmo mais próximo de ser o outro, ele, a máscara. 


\section{REFERÊNCIAS BIBLIOGRÁFICAS}

ASLAN, ODETTE. O Ator no Século XX. Editora Perspectiva, São Paulo, S.P. 1994.

La Máscara, del rito al teatro. Bogotá: Centro de Ducumentación Teatral- Editorial Iberoamericana de Teatro Ltda, 1991.

AMARAL, ANA MÁRIA. O ator e seus Duplos: Máscaras, Bonecos, Objetos. Editora SENAC, São Paulo, S.P, 2002.

. Teatro de formas animadas, São Paulo: EDUSP, 1991.

ARTAUD, ANTONIN. O Teatro e seu duplo. Editora Martins Fontes, São Paulo, S.P. 2011.

AZEVEDO, SÔNIA MACHADO DE. O papel do Corpo no Corpo do Ator. Editora Perspectiva, São Paulo, S.P. 2008.

BAUTISTA, MARIANO HURTADO. Sociologia de las mascaras. Monteagudo: Revista de literatura española, Universidad de Murcia, 1954.

BENDA, W.T. MASK. New York: Watson Guptill Publications Inc, 1994.

BERGSON, HENRI. Matéria e Memória. Editora Martins Fontes, São Paulo, S.P, 1990.

BONFITO, MATTEO, A Cinética do Invisível, Editora Perspectiva, São Paulo, S.P, 2009.

O ator-compositor. Editora Perspectiva, São Paulo,

S.P,2011

BURNIER, LUIS OTÁVIO. A Arte de Ator: Da Técnica a representação.

Editora da UNICAMP, São Paulo, S.P. 2001.

BRODT, STEPHAN. Entrevista concedida a Rudson Marcelo Duarte, 10 de Dezembro de 2016. A entrevista encontra-se transcrita no Apêndice A dessa Monografia.

CARDIM, LEANDRO NEVES. Corpo. Editora Globo, Rio de Janeiro, R.J.2009.

CARVALHO, SÔNIA MACHADO, O papel do corpo no corpo do ator. Editora Perspectiva, São Paulo, S.P, 2011.

CASTILHO, JACYAN. Ritmo e Dinâmica no Espetáculo teatral. Editora Perspectiva, São Paulo, S.P,2013. 
CHAUIU, MARILENA. Espinosa: uma filosofia da liberdade. SP: Editora Moderna, 1995

COPEAU, JACQUES. Apelos. Editora Perspectiva, São Paulo, S.P, 2013.

COSTA, FELISBERTO SABINO DA. Sob o Signo de Janus: A presença da máscara no bumba-meu-boi, no cavalo-marinho e outros aportes da contemporaneidade. Editora Anablume, São Paulo, S.P. 2014.

DELEUZE, GILLES, GATARRI, FÉLIX. Mil Platôs, Editora \#\$, São Paulo, S.P.2005.

. O Que é a Filosofia? Editora 34,

São Paulo, S.P. 2014.

Espinosa: filosofia prática. SP:

Escuta, 1981/2002.

DIDI-HUBERMANN, GEORGE. O que vemos, O que nos olha. Editora 34, São Paulo, S.P. 2014.

DUSIGNE, Jean-François. Les passeurs d'expérience. Paris, França: Éditions théâtrales, 2013

ESPINOSA, B. Ética Belo Horizonte: Autêntica Editora, 1677/2009.

FERAL, JOSETTE. Além dos limites: teoria e pratica do teatro. Editora Perspectiva, São Paulo, S.P. 2015.

Encontros com Ariane Mnouchkine, Erguendo um

Monumento ao Efêmero. Editora Senac, São Paulo, 2010.

FERRACINI, Renato. Ensaios de atuação, Editora Perspectiva, São Paulo, S.P. 2013.

FOUCAULT, MICHEL. Microfísica do Poder. Editora Graal. São Paulo, S.P, 2003.

GADAMER, Hans-George. Verdade e método I: Traços Fundamentais de uma Hermenêutica Filosófica. Editora Vozes/ Editora Universitária São Francisco, 2005.

GREINER, CHISTINE e CLAUDIA AMORIM. Leituras do Corpo. Editora Anablume, São Paulo, S.P. 2010.

GROTOWSKI, JERZY. Para um Teatro Pobre. Dulcina Editora, coleção Teatro Caleidoscópio. Brasília, D.F, 2011.

GUMBRECHT, HANS ULRICH. Produção de Presença: O que o Sentido Não Consegue Transmitir. Contraponto e PUC Rio. Rio de Janeiro, R.J, 2010. 
HAN, BYUNG-CHUL. A Sociedade da Transparência. Editora Relógio d`Água, São Paulo, S.P, 2014.

HODGE, ALISON. Actor Training. Rotledge, New Yorke, N.Y, 2010.

HUIZINGA, JOHAN. Homo Ludens. Editora Perspectiva, São Paulo, S.P, 2007.

JOUVET, Louis. O Comediante Desencarnado: Reflexões de um ator Itinerante. É Realizações, São Paulo, S.P. 2014.

LAKOFF, GEORGE and MARK JOHNSON. Metaphors We Live By. University of Chicago Press Book, 2003.

LECOQ, JACQUES. O Corpo Poético. Editora do SESC, São Paulo, S.P, 2010.

- Theatre of Movement and Gesture. Routledge, New

Yorke, N.Y, 2006.

LINARES, FERNANDO JOAQUIM JAVIER. A máscara como segunda natureza do ator: O treino do ator como uma "técnica em ação". Dissertação de Mestrado, UFMG, Belo Horizonte, M.G. 2011.

LOPES, BETH, A Máscara e a Formação do Ator. Tese de Doutorado, UNICAMP, Campinas, S.P, 1990.

MERLEAU-PONTY, MAURICE. Fenomenologia da Percepção Editora Martins Fontes, São Paulo, S.P. 2011

MILLER, JUDITH G. Ariane Mnouschkine, Rotledge. New York, NY, 2007.

NEUSCHÄFER, Anne. De l'improvisation au rite : l'épopée de notre temps. Le Théâtre du Soleil au carrefour des genres. Frankfurt am Main: Peter Lang, 2002.

PASCOUD, Fabianne e MNOUCHKINE, Ariane (ent.). A Arte do Presente: Entrevistas com Fabianne Pascoud. Tradução de Gregório Duvivier. Rio de Janeiro, RJ: Cobongo, 2011.

PARDO, ANA LUCIA org. A Teatralidade do Humano. Editora do SESC, São Paulo, S.P, 2011.

PAVIS, PATRICE. A Encenação Contemporânea: Origens, Tendências, Perspectivas. Editora Perspectiva, São Paulo, S.P. 2010.

. O Teatro no cruzamento de Culturas. Editora

Perspectiva, São Paulo, S.P. 2008.

PICON-VALIN.BEATRICE. Ariane Mnouchkine: Introdução, Escolhas e Apresentação dos Textos. Editora Riocorrente, Rio de Janeiro, R.J. 2011. 
. Le Théâtre du Soleil - Les cinquante premières années. Paris, França: Actes Sud, 2014.

SANCHEZ, JOSÉ A, et al. Repensar la dramaturgia: Errancia y transformación. CENDEAD, Centro Parraga, 2010.

SAINT-DENIS, MICHEL. Teatro: A Redescoberta do Estilo e outros Escritos. Editora Perspectiva, São Paulo, S.P. 2016.

SARRAZAC, JEAN-PIERRE. Léxico do Drama Moderno e Contemporâneo. Editora Cosac Naif, São Paulo, S.P. 2012.

FO, Dario. Manual Mínimo do Ator. Editora SENAC, São Paulo, S.P ,2004.

b) Artigos hospedados em Sites da Internet:

ASLAN, Odette. Le masque: une discipline de base au Théâtre du Soleil (1985).

Disponível em: <http://www.theatre-du-soleil.fr/thsol/nos-spectacles-etnosfilms/nos-spectacles/l-age-d-or-1975,167/le-masque-une-discipline-debase-462?lang=fr>. Acessado em 10/03/2016.

BABLET Denis e BABLET Marie-Louise. Vers un théâtre autre (1979a). Disponível em <http://www.theatre-du-soleil.fr/thsol/a-propos-du-theatre-dusoleil//historique,163/vers-un-theatre-autre>. Acessado em 10/06/2015.

. La part du rêve (1) - La cuisine,

"l'homme a besoin de pain mais il a aussi besoin de roses" (1979b). Disponível em <http://www.theatre-du-soleil.fr/thsol/nos-spectacles-et-nosfilms/nos-spectacles/lacuisine-1967-220/la-part-du-reve-1-la-cuisineI?lang=fr > . Acessado em 10/06/2015.

. Les clowns, le cirque et la vie (1979c)

Disponível em <http://www.theatre-du-soleil.fr/thsol/nos-spectacles-etnosfilms/nos-spectacles/les-clowns-1969,222/les-clowns-le-cirque-et-lavie, 1155?lang=fr $>$. Acessado em 10/05/2015.

BIRCHAL,JULIANA. Sobre Máscaras e mascaramentos in

http://projetotheatredusoleil.blogspot.com.br/search?updated-min=2014-

0101T00:00:00-02:00\&updated-max $=2015-01-01$ T00:00:00-02:00\&max-

results=11, Acesso em 12/09/2015.

CIXOUS, Hélène. Une étincelle inextinguible (1985). Disponível em <http://www.theatre-du-soleil.fr/thsol/nos-spectacles-et-nos-films/nosspectacles/lhistoire-terrible-mais-inachevee/une-etincelleinextinguible?lang=fr $>$. Acessado em10/05/2015.

KANE, OMAR. Marshall MacLuhan e a Teoria Midiática: Dívidas e Críticas, in: http://www.academia.edu/6192920/Marshall_McLuhan_e_a_Teoria_Midi\%C3 \%A1 tica_D\%C3\%ADvidas_e_Cr\%C3\%ADticas. Acessado em 20/11/2016. 
PICON -VALLIN, Béatrice. L'Orient au Théâtre du Soleil: le pays imaginaire, les sources concrètes, le travail original - rencontre avec Ariane Mnouchkine et Hélène Cixous. (2004). Disponível em <http://www.theatre-du soleil.fr/thsol/sourcesorientales/des-traditions-orientales-a-la/l-influence-de-lorient-au-theatre/l-orientau-theatre-du-soleil-le? lang=fr $>$. Acessado em 10/05/2015.

Rêver à un espace qui permettrait toutes les apparitions (2004a). Disponível em http://www.theatre-dusoleil.fr/thsol/sourcesorientales/des-traditions-orientales-a-la/l-influence-de-lorient-au-theatre/rever-aun-espace-qui-permettrait

c) Filmografia

AU Soleil même la nuit. Direção de Eric Carmon, Catherine Vilpoux e Théâtre du Soleil. Produção AGAT Films, La Sept ARTE e Theâtre du Soleil. Paris: Bel Air Classiques, 2011. 2 DVD9 (160 min), NTSC, Cor, Som. Documentário. MARIONNETE et théâtre d'objet. Produção: CRDP De L'Academie de Lyon, 2010. 2 DVD (240 min), PAL, Cor, Som. Documentário.

TAMBOURS sur la digue. Direção de Ariane Mnouchkine. Produção: Le Théâtre du Soleil, Bel Air Media, ARTE France, CNDP, ZDF Theaterkanal. 